\title{
Flora of Espírito Santo, Brazil Flora of Espírito Santo: Commelinaceae
}

\author{
Quélita dos Santos Moraes ${ }^{1,2,5,7}$, Marco Octávio de Oliveira Pellegrini ${ }^{3,4}$ \& Anderson Alves-Araújo ${ }^{1,2,6}$
}

\begin{abstract}
This work is a part of the Flora do Espírito Santo project. The aim was to morphologically characterize the species of Commelinaceae occurring in the state of Espírito Santo and provide data on their geographical distribution, phenology, and comments. Fieldwork and herbarium studies were carried out. A total of 38 species, arranged in 10 genera, were recorded. Dichorisandra is the richest genus (17 species), followed by Commelina (seven spp.), Tradescantia (four spp.), Siderasis (three spp.), Tripogandra (two spp.), and Aneilema, Callisia, Floscopa, Gibasis and Tinantia (one species each). Two species are herein described as new to science, and the synonymization of $D$. albomarginata is proposed under the older D. procera. Inflorescence (type and position), stamens (number, color, and anther dehiscence), fruit (shape and ornamentation), and seeds (ornamentation, the position of the embryotega, and hilum shape) are the key diagnostic morphological characters for genus and species delimitation. Most of the species richness and abundance are concentrated in the mountain region of Espírito Santo, one of the largest forest areas in the state, showing the importance of conserving the remaining Atlantic Forest's fragments.
\end{abstract}

Key words: Atlantic Forest, Commelina, Commelinales, Dichorisandra, Neotropical flora.

\section{Resumo}

O presente trabalho é parte integrante do projeto Flora do Espírito Santo. O objetivo foi caracterizar morfologicamente as espécies de Commelinaceae ocorrentes no estado do Espírito Santo e fornecer dados sobre sua distribuição geográfica, fenologia e comentários. Expedições de coleta e análises de material de herbário foram realizados, buscando inventariar as espécies ocorrentes no estado. Um total de 38 espécies em 10 gêneros foram registradas, sendo Dichorisandra o gênero mais representativo em números de espécies (17 spp.), seguido por Commelina (sete spp.), Tradescantia (quatro spp.), Siderasis (três spp.), Tripogandra (duas spp.) e Aneilema, Callisia, Floscopa, Gibasis e Tinantia (uma sp. cada). Duas espécies são aqui descritas como novas para a ciência e, a sinonimização de $D$. albomarginata sob D. procera é proposto. Caracteres morfológicos como: inflorescência (tipo e posição), estames (número, cor e deiscência), fruto (forma e ornamentação) e sementes (ornamentação, posição da embrioteca, e forma do hilo) são os principais caracteres diagnósticos para delimitação de gênero e espécie. A maior riqueza e abundância das espécies concentra-se na região serrana do Espírito Santo, uma das maiores áreas florestais do estado, evidenciando a importância da conservação e preservação dos fragmentos remanescentes de Mata Atlântica.

Palavras-chave: Floresta Atlântica, Commelina, Commelinales, Dichorisandra, flora Neotropical.

\footnotetext{
${ }^{1}$ Universidade Estadual de Feira de Santana, Prog. Pós-graduação em Botânica, Feira de Santana, BA, Brasil.

${ }^{2}$ Universidade Federal do Espírito Santo-UFES, Depto. Ciências Agrárias e Biológicas, São Mateus, ES, Brasil.

${ }^{3}$ Universidade Federal Rural da Amazônia / Museu Paraense Emilio Goeldi, Terra Firme, Belém, PA, Brazil.

${ }^{4}$ Scientifik Consultoria, Petrópolis, RJ, Brazil. ORCID: < https://orcid.org/0000-0002-8783-1362>.

${ }^{5}$ ORCID: <https://orcid.org/0000-0002-7231-8259>.

${ }^{6}$ ORCID: $<$ https://orcid.org/0000-0001-5810-5145>.

${ }^{7}$ Author for correspondence: smquelita@gmail.com
} 


\section{Introduction}

Commelinaceae comprises 41 genera and 720 species (Govaerts \& Faden 2011), divided into two subfamilies: Cartonematoideae with only two genera, the Australian Cartonema with 11 species, and the monospecific Triceratella from South Africa; and Commelinoideae, with 39 genera and the remaining species, being Pantropical (Faden \& Hunt 1991). Commelina (230 species) is the most diverse genus, followed by Tradescantia (90 species), Aneilema (65 species), and Dichorisandra (63 species) (Hardy \& Faden 2004; Aona 2008; Pellegrini 2017b, 2019).

The family presents considerable morphological variation, especially regarding its inflorescences, flowers, and seeds (Faden 1998). This wide variation makes morphological characters relatively tricky to interpret and has led to many taxonomic and systematic issues (Evans et al. 2003; Pellegrini 2019). Characters such as habit, inflorescence architecture, the number, color and ornamentation of stamens, anther dehiscence, and fruit and seed morphology are some of the most taxonomically relevant characters in the family (Pellegrini 2019).

Studies in the family, especially addressing the morphology and delimitation of genera and species, are still very scarce (Pellegrini 2017b, 2019). In Brazil, only a handful of studies have been published for Commelinaceae: 1) floristic studies (Barreto 1997; Maia 2006; Aona \& Pellegrini 2014; Pellegrini \& Forzza 2017; Aona et al. 2020);2) taxonomic studies and revisions (Aona 2008; Aona et al. 2016a; Pellegrini 2017b, 2018; Pellegrini \& Almeida 2016; Pellegrini \& Faden 2017; Pellegrini et al. 2013, 2015, 2016, 2017); and 3) the description of new species (Aona-Pinheiro \& Amaral 2012; Aona et al. 2012, 2014, 2016b, 2016c; Pellegrini 2016, 2017a, 2018; Pellegrini \& Faden 2017; Pellegrini \& Forzza 2017; Pellegrini et al. 2017; Moraes et al. 2019, 2020).

In Brazil, 116 taxa are recorded, of which 59 are endemic. The Atlantic Forest domain has the highest number of species (80 spp.), followed by the Cerrado (37 spp.), the Caatinga (31 spp.), the Amazon Forest (30 spp.), and the Pampa and Pantanal (16 spp., each) (Aona et al. 2020). Previous studies (Dutra et al. 2015; Aona et al. 2020) have recorded 33 species arranged in ten genera for the state of Espírito Santo.
Of the recorded genera, Dichorisandra is the most diverse in the state (13 spp.), followed by Commelina (six spp.) and Tradescantia (three spp.) (Dutra et al. 2015; Aona et al. 2020).

As part of the Flora do Espírito Santo project, we provide a floristic treatment for Commelinaceae in the state of Espírito Santo, aiming to clarify the number, identity and delimitation of accepted taxa. We present descriptions, identification keys, comments, phenological information, distribution maps, and illustrations for all taxa.

\section{Material and Methods}

This study was based on fieldwork and analysis of material from the following herbaria: ALCB, BHCB, CEPEC, CESJ, CVRD, ESA, FLOR, HB, HRCB, HUEFS, HUEM, HURB, MBM, MBML, MO, NY, P, R, RB, RBR, RFA, SAMES, SP, SPF, SPSF, U, UEC, UPCB, US, VIC, and VIES (acronyms according to Thiers, continuously updated). Field expeditions were carried out mainly at localities with previous records gathered from the visited herbaria and online databases (CRIA 2020; GBIF 2018). Samples were collected and dried according to the usual taxonomic procedures (Mori et al. 2011). Vouchers were incorporated at VIES herbarium, and duplicates were sent to RB and US.

For species identification, samples were compared to type specimens, protologues, and specialized literature (e.g., Aona 2008; Pellegrini et al. 2016; Pellegrini 2016; Pellegrini \& Faden 2017; Pellegrini \& Forzza 2017). Only native and naturalized species were included in the present study, thus, excluding species with no proof of having escaped cultivation. Sterile specimens were collected and kept under cultivation at the Universidade Federal do Espírito Santo (UFES), aiming to photograph and analyze fresh flowers, fruits, and seeds.

Morphological terminologies follow different authors depending on the structures: Radford et al. (1974) and Harris \& Harris (2001) for indumentum and shape; Weberling (1965, 1989) and Panigo et al. (2011) for inflorescence morphology; Spjut (1994) for fruits; and Faden (1991) for seed morphology. The richness analyzes and species records were done using the Circular Neighborhood Method (CNM), facilitated by the DIVA-GIS 7.5.0 software (Hijmans et al. 2012). For the distribution maps, Quantum-GIS software version 2.12 was used. 


\section{Results and Discussion}

A total of 38 taxa arranged in 10 genera are accepted by us for the state of Espírito Santo, including native (37) and naturalized (one) species. Two species, Dichorisandra aonae and $D$. glandulosa, are herein described as new to science. A third species, Dichorisandra sp., most likely represents a new species but will be described in a posterior study.

Tradescantia pallida (Rose) Hunt (1975: 452), T. spathacea Sw. (1788: 57), and Tripogandra elata Hunt (1979: 405) were only observed under cultivation. Alternatively, Tradescantia zebrina hort. ex Bosse (1849: 655)is broadly recognized as an aggressive invasive, being commonly found in Espírito Santo in anthropized areas. Commelina villosa Clarke ex Chodat \& Hassler (1901: 438), Dichorisandra glaziovii Taubert (1890: 2), D. perforans Clarke (1881: 281), D. thyrsiflora Mikan (1820: 3), and Siderasis fuscata (Lodd.) Moore (1956: 28) were recorded for the state by Dutra et al. (2015). Nonetheless, these species' occurrence was not confirmed and were misidentifications. Samples determined as Commelina villosa, Dichorisandra glaziovii, and D. perforans respectively correspond to $C$. benghalensis Linnaeus (1753: 41), D. striatula Moraes \& Pellegrini (2019: 783), and D. penduliflora Kunth (1843: 114). Furthermore, D. thyrsiflora is often used to identify several Espírito Santo collections. Those samples correspond to D. procera Martius ex Schultes f. (1830: 1187), which is morphologically similar but can be distinguished by its poricidal anthers with two apical pores (vs. one in $D$. thyrsiflora). Siderasis fuscata, which is endemic to the state of Rio de Janeiro, was erroneously used to identify specimens of $S$. albofasciata (Pellegrini 2017a; Pellegrini \& Faden 2017).

Dichorisandra is the richest genus with 17 species, followed by Commelina (seven spp.), Tradescantia (four spp.), Siderasis (three spp.), Tripogandra (two, spp.), and Aneilema, Callisia, Floscopa, Gibasis, and Tinantia with one species each. In terms of species' number and records, the Central (mainly Linhares and Colatina municipalities) and Metropolitan macroregions (Santa Teresa) (IBGE 2017) of Espírito Santo are the richest areas which show a higher number of species and the greatest number of records of Commelinaceae (Fig. 1). These macroregions include different vegetation types such as seasonally dry forests

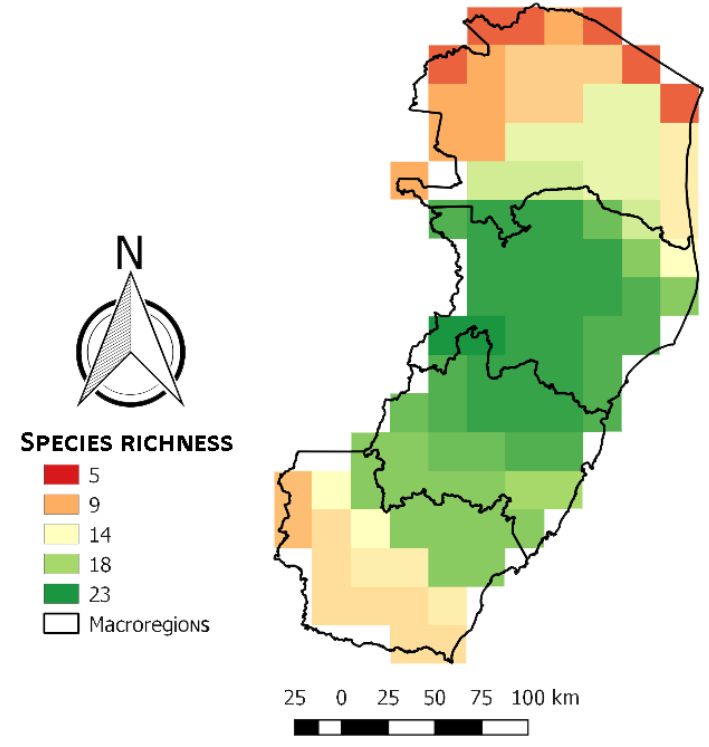

Figure 1 - Species richness analysis of Commelinaceae from the state of Espírito Santo, Brazil.

and rainforests (Garbin et al. 2017), explaining the abundance of Commelinaceae. Most Neotropical Commelinaceae species are associated with humid and shaded environments, growing mainly in rainforests and remnants of seasonally dry forests associated with inselbergs (Hardy \& Faden 2004; Barreto 2005; Pellegrini \& Forzza 2017). Moreover, our results indicate that this large number of records to be associated with focused and intense collection efforts in the largest forested areas in Espírito Santo (Fig. 2), in addition, other studies in the state as Murray-Smith et al. (2009), Werneck et al. (2011), Dutra et al. (2015), Luber et al. 2016), Garbin et al. (2017) indicate the number of endemic species of an area is directly affected by its collection effort.

\section{Taxonomic treatment}

Commelinaceae Mirb., Hist. Nat. P1. 8: 177. 1804.

Herbs annual or perennial, usually succulent, terrestrial, rupicolous, aquatic, rarely epiphytes. Roots fibrous or tuberous. Stems ascending, erect or prostrate, sometimes decumbent, vining or scrambling. Leaves alternate, distichously or spirally-alternate, sessile or pseudopetiolate; sheaths closed, veins parallel. Inflorescences thyrsoid, sessile or pedunculate; basal bract tubular, bracteose, leaf-like or spathaceous; main axis developed or not; cincinni 1-many, free or fused back to back, alternate, subopposite, 


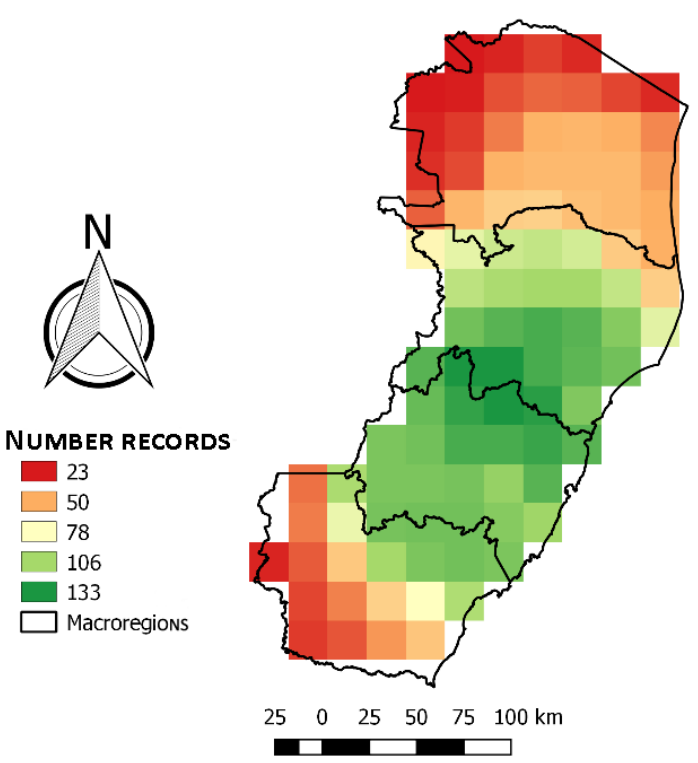

Figure 2 - Number records of Commelinaceae from the state of Espírito Santo, Brazil.

verticillate or fasciculate; cincinnus bract absent, bracteose, leaf-like or spathaceous. Flowers actinomorphic, zygomorphic or asymmetric (enantiostylous), chasmogamous, rarely cleistogamous, bisexual or staminate, rarely pistillate; sepals 3 , sepaloid; petals 3 , petaloid, generally deliquescent at post-anthesis; stamens 3-6, filaments glabrous or bearded, staminodes 1-3 when present; ovary superior, 2-3-locular. Fruits a loculicidal capsule, rarely valves only partially dehiscent or indehiscent. Seeds 1-many per locule, triangular or reniform to quadrangular; embryotega dorsal, semidorsal, lateral or semilateral; hilum punctiform, linear or C-shaped.

The family is characterized by its usually succulent herbs, which can be terrestrial, rupicolous, or aquatic, rarely epiphytes. Leaves spirally or distichously-alternate, sessile or pseudopetiolate; sheaths closed. The inflorescences are thyrsoid, terminal, axillary or basal, composed of few or numerous cincinni, and sometimes subtended by leaf-like or spathaceous bracts. The flowers are ephemeral, with generally deliquescent petals, and the androecium is highly variable. The fruits are most commonly loculicidal capsules but can also be indehiscent or partially dehiscent, more rarely a berry. The seeds consistently present an embryotega (i.e., calyptra), through which the embryo germinates denominated embryotega (Faden \& Hunt 1991; Faden 1998).

\section{Key to the genera of Commelinaceae in the state of Espírito Santo}

1. Roots fibrous with ellipsoid to fusiform tubers at apex; filaments stout; fruits thick-walled; seeds arillate

2. Stamens 5-6, staminodes sometimes present, anthers basifixed, dehiscence poricidal or introrsely rimose (but functionally poricidal) or truly poricidal dehiscing by one or two apical pores, anthers sacs parallel, elongate, 3 to 4 times longer than the filaments, connectives inconspicuous

4. Dichorisandra

2'. Stamens 6, staminodes absent, anthers dorsifixed, dehiscence extrorsely rimose, anther sacs divergent,

C-shaped, 3 to 4 times shorter than the filaments, connectives expanded 7. Siderasis

1'. Roots fibrous without ellipsoid to fusiform tubers at apex; filaments thin; fruits thin-walled; seeds exarillate.

3. Inflorescences reduced to a double-cincinni fused back to back, subopposite

4. Stems and leaves dimorphic when flowering; inflorescences sessile, enclosed by the subtending leaf-sheath; connectives conspicuous, flabellate, stigma penicillate .....

4'. Stems and leaves monomorphic; inflorescences pedunculate, exserted from the subtending leaf-sheath; connectives inconspicuous, curved, rhomboid or quadrangular, stigma punctate, truncate, capitate or trilobate...

5. Cincinni bracts leaf-like or spathaceous; flowers actinomorphic, without display torsion; stamens 6, homomorphic or subequal. 9. Tradescantia

5'. Cincinni bracts vestigial; flowers zygomorphic, with a $60^{\circ}$ display torsion; stamens 6 ( 3 sometimes staminodial), dimorphic 10. Tripogandra

3'. Inflorescences 1-many cincinni, free, alternate, verticillate or fasciculate. 6 
6. Plants aquatic or paludal; bracteoles rhomboid; gynoecium 2-carpellate, stipitate; embryotega discolorousous with the testa 5. Floscopa (F. glabrata)

6'. Plants terrestrial or rupicolous, rarely epiphytic; bracteoles cup-shaped or triangular to ovate; gynoecium 3-carpellate, sessile; embryotega concolorous with the testa .....

7. Hook-trichomes present in the inflorescence (sometimes also in the pedicels and sepals); lateral petals clawed, medial petal sessile or shortly-clawed; staminodes present, posterior... 8

8. Inflorescences leaf-opposed, basal bract spathaceous, cincinni (1-)2, fasciculate; cincinnus bracts absent; antherodes X-shaped. 3. Commelina

8'. Inflorescence terminal, basal bract bracteose to leaf-like, cincinni 3-5, alternate; cincinnus bracts present; antherodes bilobed..... 1. Aneilema (A. brasiliense)

7'. Hook-trichomes absent in the inflorescence; lateral petals sessile; staminodes absent.....

9. Basal bract tubular and hyaline, cincinnus bracts free from the cincinnus peduncle, bracteoles hyaline; flowers actinomorphic, petals white, stamens homomorphic, filaments and style straight; embryotega dorsal, hilum linear.. 6. Gibasis (G. geniculata)

9'. Basal bract leaf-like, cincinnus bracts fused to the cincinnus peduncle, bracteoles green; flowers zygomorphic, petals purple or blue, stamens dimorphic, filaments and style curved; embryotega lateral, hilum C-shaped 8. Tinantia (T. erecta)

1. Aneilema brasiliense C.B.Clarke in De Candolle \& De Candolle, Monogr. Phan., 3:225, 1881.

Figs. 3; 4a-b; 5a-d

Herbs $30-60 \mathrm{~cm}$ tall, annual, terrestrial. Roots fibrous, without terminal tubers. Stems erect, branched, monomorphic when flowering, green, puberulous, trichomes hyaline. Leaves spirally-alternate; sheaths $0.8-1.5 \mathrm{~cm}$ long, puberulous, margins setose; pseudopetiole $0.5-1.6$ $\mathrm{cm}$ long, puberulous, trichomes hyaline; blades $8-17 \times 2.5-5.5 \mathrm{~cm}$, ovate to elliptic-lanceolate, concolorous, green, shortly-hispid on both sides, base asymmetric, cuneate to round, apex acute to acuminate. Inflorescences terminal, pedunculate, erect; basal bract bracteose to leaf-like; cincinni 3-5, alternate, free, pedunculate, 3-9-flowered; cincinnus peduncle $1.5-3.5 \mathrm{~cm}$ long; cincinnus bract $0.5-2 \times 0.3-0.6 \mathrm{~cm}$, bracteose to leaf-like, elliptic, green to brown, puberulous; bracteoles $0.1-0.4 \mathrm{~mm}$ long, elliptic to lanceolate, green, sparsely puberulous. Flowers zygomorphic, bisexual; hook-trichomes present in the pedicels and sepals pedicels $3-10 \mathrm{~mm}$ long, puberulous; sepals 3-6 $\times 2-4 \mathrm{~mm}$, elliptic to oblong, green, puberulous; petals 4-7.5 × 3-4.5 mm, unequal, light pink or lilac, the laterals clawed, medial petals shortly-clawed, sessile; stamens 3, anterior, medial smaller than the laterals, filaments $2-7 \mathrm{~mm}$ long, glabrous, curved, anthers $0.4-1.1 \times 0.6-0.8 \mathrm{~mm}$, rimose, yellow; staminodes 3 , subequal, posterior, antherodes $0.2-0.5 \times 0.3-0.5 \mathrm{~mm}$, bilobed, purple; ovary $1.5-2 \times 1-1.5 \mathrm{~mm}$, glabrous, style $3.5-5$ $\mathrm{mm}$ long, curved, stigma capitate. Capsules 5-8.5 $\times 2.5-4.5 \mathrm{~mm}$, obovoid to ellipsoid, thin-walled, green, glabrous. Seeds 1.5-2.5 × 1.3-4 mm, exarillate, testa scrobiculate, brown; hilum linear; embryotega lateral, concolorous with the testa.

Specimens examined: Alegre, 28.I.2009, fl., V.C. Manhães 202 (MBML, VIES); São João do Norte, PCH Santa Fé, ca. $1 \mathrm{~km} \mathrm{~N}$ da ponte, 24.I.2011, fl., J.R. Pirani et al. 6236 (HURB, SPF). Nova Venécia, APA Pedra do Elefante, Serra de Baixo, Mata da Fazenda Santa Rita, 15.IV.2009, fl., C.N. de Fraga 2531 (CEPEC, MBM, MBML, RB, UPCB); 16.III.2015, fr., N.T.L. Pena 143 (VIES); 16.III.2015, fr., N.T.L. Pena 144 (VIES16. III.2015, fr., N.T.L. Pena 145 (VIES); 16.V.2015, fr.,

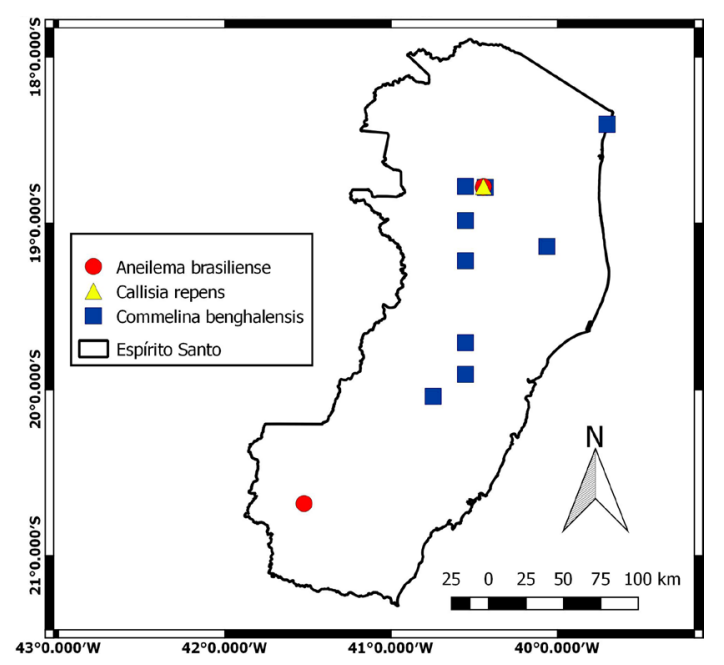

Figure 3 - Geographic distribution of Aneilema brasiliense, Callisia repens and Commelina benghalensis in the state of Espírito Santo. 

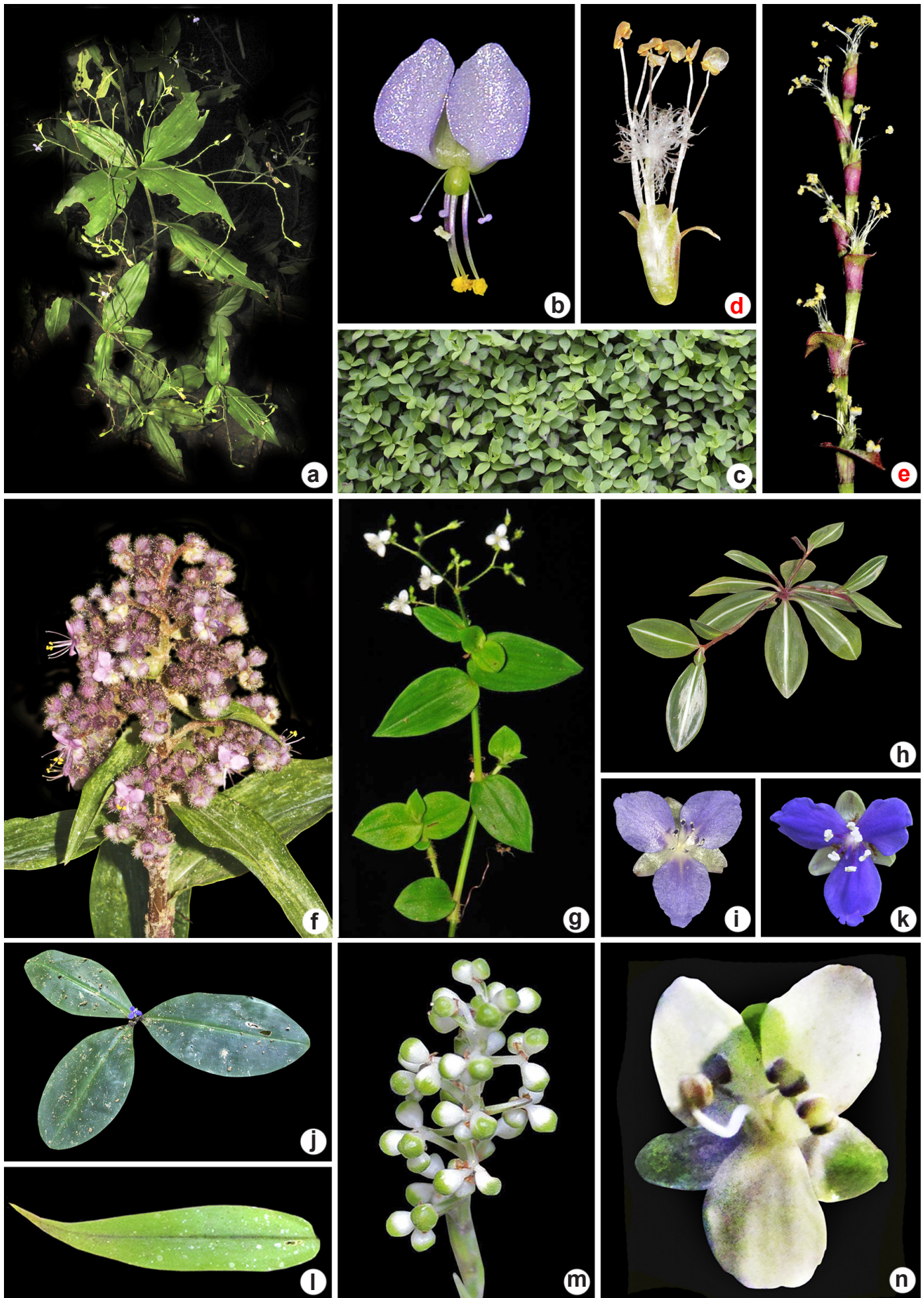

Figure 4 - a-b. Aneilema brasiliense - a. habit; b. front view of a bisexual flower. c-e. Callisia repens - c. habit; d. bisexual flower; e. detail of inflorescence. f. Floscopa glabrata - detail of inflorescence. g. Gibasis geniculate - habit. h-i. Siderasis medusoides - h. habit; i. front view of a bisexual flower. j-k. Siderasis albofasciata - j. habit; k. front view of a bisexual flower. 1-n. Siderasis zorzanellii - 1. adaxial side of the leaf-blade; m. detail of inflorescence; $n$. front view of a bisexual flower. (Photos: a-b, g. CN Fraga; c-f, h-i. MOO Pellegrini; j-k. P Fiaschi; 1-n. JPL Zorzanelli). 
N.T.L. Pena 146 (VIES); 23.VI.2015, fr., N.T.L. Pena 324 (VIES); trilha para a gameleira, 20.III.2017, fl., Q.S. Moraes 146 (RB); Fazenda Santa Rita, ao pé da Pedra da Torre, 21.II.2018, fl., J. Gurtler \& S.C. Dutra JAC 470 (VIES); 21.II.2018, fl., J. Gurtler \& S.C. Dutra JAC 471 (VIES); 21.II.2018, fl., J. Gurtler \& S.C. Dutra JAC 472 (VIES). Santa Teresa, Pedra da Onça, 6.I.2000, fl., V. Demuner 482 (MBML); Várzea Alegre, cachoeira do Madalão, 30.VIII.2001, fl., L. Kollmann 4450 (MBML); São João de Petrópolis, E.A.F.S.T., 24.I.2006, fl., L. Kollmann 8603 (MBML); 21.I.1999, fl., L. Kollmann 1656 (MBML); Valão de São Brás, área da E.A.F.S.T., 16.I.2007, fl., R.C. Britto 152 (MBML).

Aneilema brasiliense occurs in Venezuela and Northeastern and Southeastern Brazil (Faden 1991; Aona et al. 2020). In Espírito Santo, the species occurs in seasonally dry forests (Fig. 3 ). The specimens from the state present leaf indumentum shortly-hispid ranging from sparse to dense trichomes and petals varying in color from light pink to lilac. Despite this morphological variation, other features like stamen number and shape, inflorescence architecture, fruit shape, seed ornamentation, and embryotega position and constant and diagnostic. Aneilema brasiliense has not had its conservation assessed yet. Flowers and fruits were recorded from January to May and August.

2. Callisia repens (Jacq.) L., Sp. Pl., ed. 2. 1: 62. 1762.

Figs. 3; 4c-e; 5e-h

Herbs $10-20 \mathrm{~cm}$ tall when in bloom, perennial, rupicolous or terrestrial, rarely epiphytic, mat-forming habit. Roots fibrous, without terminal tubers. Stems prostrate, decumbent, becoming ascending to erect when in bloom, branched, green or vinaceous, pubescent, trichomes hyaline, dimorphic when flowering. Leaves distichouslyalternate; sheaths 2-4 $\mathrm{mm}$ long, sparsely pubescent, margins ciliate; sessile, rarely with an inconspicuous pseudopetiole; blades 0.6-1.2 $\times$ $0.9-1.1 \mathrm{~cm}$, ovate to cordate, discolorous, abaxially light green, adaxially green, sometimes completely or speckled vinaceous, glabrous on both sides, base asymmetric, round to cordate, apex acute to acuminate. Inflorescences enclosed by the subtending leaf-sheath, sessile, erect; basal bract tubular and hyaline; cincinni 2, subopposite, fused back to back, sessile, 1-3-flowered, cincinnus bract 2-3 × 1-1.5 mm, elliptic, light green, pubescent; bracteoles $0.5-2 \times 0.5-0.7 \mathrm{~mm}$, lanceolate, paleaceous, glabrous. Flowers actinomorphic, bisexual, staminate or pistillate; hook-trichomes absent; pedicels 1-2 mm long, glabrous; sepals
4-5 × 1.5-2 mm, lanceolate, green, pubescent; petals 4-6 $\times 1.5-2.7 \mathrm{~mm}$, equal, lanceolate, white to light green; stamens 6 , homomorphic, filaments 5-6 mm long, glabrous, anthers $0.2-0.5 \times 0.4-0.6$ $\mathrm{mm}$, rimose, yellow; ovary $1.2-1.9 \times 1-1.7$ $\mathrm{mm}$, glabrous, style 5-7 mm long, erect, stigma penicillate. Capsules $1.5-2.2 \times 1.3-2 \mathrm{~mm}$, broadly oblongoid to globose, thin-walled, brown, glabrous. Seeds $0.8-1.3 \times 0.5-1 \mathrm{~mm}$, exarillate, testa striate, brown; hilum punctiform; embryotega dorsal, concolorous with the testa.

Specimens examined: Alegre, 20.VIII.1979, fl., A.F.M. de Albuquerque (MBML 1228). Santa Teresa, Estação Biológica Santa Lúcia, trilha para o Túmulo de Augusto Ruschi, 26.VI.2009, fl. and fr., M.O.O. Pellegrini 250 (RB, VIES).

Callisia repens is native to tropical America from southern United States to Argentina. However, it can be found naturalized in other continents (Hunt 1986a; Tseng et al. 2010). In Brazil, it occurs in the Caatinga and Atlantic Forest domains (Aona et al. 2020) (Fig. 3). It can be recognized by its mat-forming habit, decumbent stems, leaf-blades green with vinaceous margins, and anemophilous flowers due to the reduced corolla, expanded anther connectives, and exserted stamens. Callisia repens has not had its conservation assessed yet. Flowers and fruits were recorded from June to August.

\section{Commelina L., Sp. P1. 1: 40-41. 1753.}

Herbs annual or perennial, aquatic, rupicolous or terrestrial, rarely epiphytic. Roots fibrous, without terminal tubers. Stems erect or prostrate and ascending at the apex, usually branched, green, monomorphic when flowering. Leaves distichouslyalternate, sessile or pseudopetiolate. Inflorescences leaf-opposed, pedunculate, erect or patent to slightly pendulous; basal bract spathaceous; cincinni 1-2, fasciculate, free, pedunculate, 1-manyflowered; cincinnus bract absent; bracteoles cup-shaped, hyaline, early deciduous, glabrous. Flowers enantiostylous, chasmogamous, rarely cleistogamous and underground, bisexual or staminate; sepals, unequal, free or the paired two connate; hook-trichomes present in the pedicels and sepals; petals 3, unequal, blue or purple to lilac, rarely white, the laterals clawed, the medial sessile or shortly-clawed; stamens 3, anterior, dimorphic, filaments glabrous, anthers rimose; staminodes 3, posterior, antherodes X-shaped; ovary 3-locular, ellipsoid to globose, style curved, stigma truncate, capitate or trilobate. Capsules loculicidal, sometimes indehiscent or only partially dehiscent, 

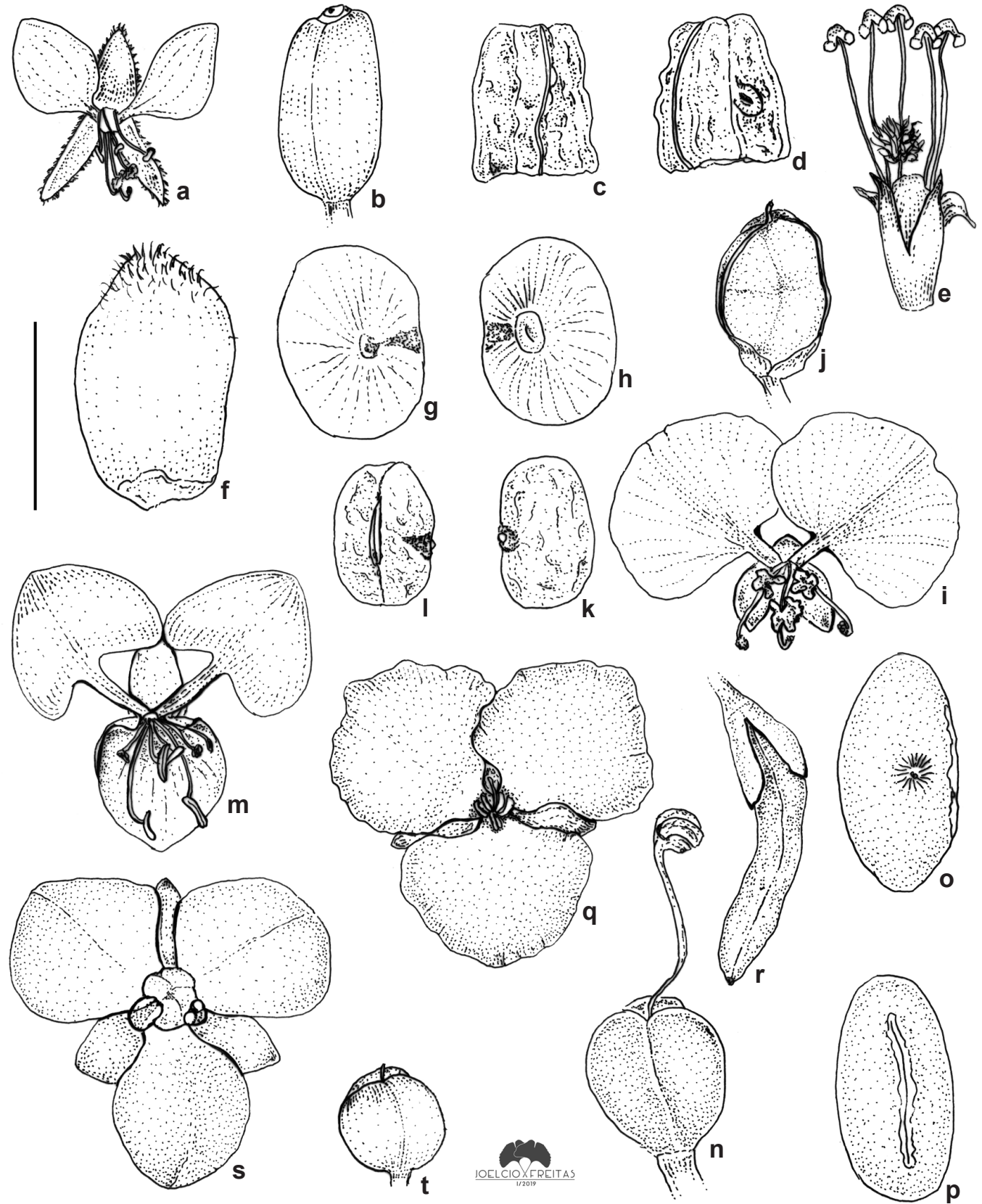

Figure 5 - a-d. Aneilema brasiliense - a. front view of a bisexual flower; b. immature capsule; c-d. seed showing the scrobiculate ornamentation; c. detail of lateral embryotega; d. details of the linear hilum. e-h. Callisia repens - e. bisexual flower; f. immature capsule; g-h. seed showing the foveolate ornamentation - g. detail of semilateral embryotega; h. details of the punctiform hilum. i-1. Commelina benghalensis - i. front view of a bisexual flower; $j$. immature capsule; $\mathrm{k}-1$. seed showing the foveolate ornamentation; $\mathrm{k}$. detail of lateral embryotega; 1 . details of the linear hilum. m. Commelina longicaulis - front view of a bisexual flower. n-p. Commelina erecta - n. immature capsule; o-p. seed showing the foveolate ornamentation - o. detail of lateral embryotega; p. details of the linear hilum. q-r. Dichorisandra penduliflora - q. front view of a bisexual flower; r. immature ellipsoid capsule. s-t. Dichorisandra procera $-\mathrm{s}$. front view of a bisexual flower; $\mathrm{t}$. immature globose capsule. Scale bars: $\mathrm{a}, \mathrm{e}=8 \mathrm{~mm} ; \mathrm{b}=8.5 \mathrm{~mm}$; $\mathrm{c}-\mathrm{d}$ $=3 \mathrm{~mm} ; \mathrm{f}, \mathrm{k}, \mathrm{l}=2 \mathrm{~mm} ; \mathrm{g}, \mathrm{h}, \mathrm{o}, \mathrm{p}=1.5 \mathrm{~mm} ; \mathrm{i}, \mathrm{q}=1.5 \mathrm{~cm} ; \mathrm{j}, \mathrm{n}=6 \mathrm{~mm} ; \mathrm{m}=5 \mathrm{~mm} ; \mathrm{r}=3 \mathrm{~cm} ; \mathrm{s}=1.6 \mathrm{~cm} ; \mathrm{t}=2.5 \mathrm{~cm}$. (a-d. Moraes 146; e-h. Pellegrini 250; i-1. Moraes 156; m. Moraes 284; n-p. Moraes 157; q-r. Moraes et al. 238 ; s-t. Moraes et al. 306). Line drawings by J Freitas. 
globose or ovoid, thin-walled. Seeds exarillate, testa foveolate or scrobiculate, rarely with a lateral, fleshy appendage; hilum linear or C-shaped; embryotega semilateral or lateral, concolorous with the testa.

Commelina is the largest genus in the family (ca. 230 species) with an almost cosmopolitan distribution, being one of the most complicated taxonomically (Faden 1998; Hardy \& Faden
2004; Pellegrini \& Forzza 2017). In Brazil, nine species are currently recognized (Aona et al. 2020). Commelina is easily differentiated by its spathaceous basal bract, inflorescences reduced to (1-)2 fasciculate cincinni, enantiostylous flowers, unequal petals, generally sky blue (sometimes white, lilac and purple, rarely pink, orange and yellow), and X-shaped antherodes (Faden 1998; Pellegrini 2019).

\section{Key to the species of Commelina of the state of Espírito Santo}

1. Inflorescences axillary and leaf-opposed, long pedunculate (peduncle the same length or longer than

$1 / 2$ length of the spathe), spathe base free; medial petal shortly-clawed.

2. Leaves pseudopetiolate; anthers purple to blue, antherodes yellow, ovary glabrous.....

3.2. Commelina diffusa

2'. Leaves sessile; anthers yellow, antherodes white, ovary pubescent

3.4. Commelina longicaulis

1'. Inflorescences terminal or apparently so, short-pedunculate to sessile (peduncle shorter than 1/2 length of the spathe), spathe base connate at least at base; medial petal sessile.

3. Spathes much lighter than the leaves (in vivo), the connate base splitting open in fruit; paired petals white, medial staminode aborted

3.6. Commelina rufipes

3'. Spathes the same color as the leaves (in vivo), base remaining connate in fruit; paired petals lilac to purple or blue (rarely white), medial staminode present

4. Leaf-blades broadly ovate to obovate; cleistogamous subterraneous flowers present, medial petal trullate, ovary minutely pilose, stigma truncate; seeds black, testa shallowly reticulate

3.1. Commelina benghalensis

4'. Leaf-blades elliptic, lanceolate to oblanceolate; cleistogamous subterraneous flowers absent, medial petal oblong to spathulate to obovate, ovary glabrous, stigma trilobate; seeds dark brown, testa shallowly foveolate, foveolate or rugose foveolate.

5. Leaf-sheaths with auriculate margin; medial petal hyaline; seeds with a lateral appendage. 3.3. Commelina erecta

5'. Leaf-sheaths with upright margin; medial petal concolorous to the lateral petals or slightly lighter; seeds lacking a lateral appendage....

6. Leaf-sheaths scabrid, blades scabrid on both sides; spathe connate up to mid-length, upper cincinnus developed, peduncle exserted from the spathe; fruits tan-colored when mature; seeds testa foveolate to rugose-foveolate, hilum linear..

3.5. Commelina robusta

6'. Leaf-sheaths hirsute, blades abaxially hirsute along the midvein; spathe connate almost to the apex, upper cincinnus aborted, peduncle included in the spathe; fruits opaque white when mature; seeds testa smooth, hilum C-shaped .

3.7. Commelina scabrata

3.1. Commelina benghalensis L., Sp. Pl. 1: 41. 1753.

Figs. 3; 5i-1; 6a

Herbs $30-50 \mathrm{~cm}$ tall., annual or perennial, rupicolous or terrestrial. Stems branched, pubescent, trichomes hyaline. Leaf-sheaths 0.7-1.7 cm long, hirsute, margins hispid, upright; pseudopetiole 2-5 mm long, hirsute, trichomes hyaline; blades $1.4-11.8 \times 1-4.2 \mathrm{~cm}$, broadly ovate to obovate, concolorous, green, hirsute on both sides, base asymmetric, round, apex obtuse to acute. Inflorescence apparently terminal, erect; peduncle 3-7 mm long; spathe $0.7-1.8 \times 1.2-2.6$ $\mathrm{cm}$, transversally rhomboid, green, hirsute, base connate, remaining connate in fruit, apex acute; 
upper cincinnus developed, exerted, lower cincinnus 4-6-flowered. Flowers chasmogamous, underground and cleistogamous present, bisexual or staminate; pedicels $0.3-0.8 \mathrm{~cm}$ long, glabrous; upper sepal 2-3.5 × 1.5-2.3 mm, cymbiform, white to light green, glabrous, lower sepals 4-5 × 3-4 $\mathrm{mm}$, very broadly ovate, connate up to mid-length, white, glabrous; paired petals $0.8-1.4 \times 0.9-1.2$ $\mathrm{cm}$, limb reniform, blue to dark blue, medial petal 3-4 × 1-1.5 mm, sessile, trullate, light blue to blue; medial stamen smaller than the laterals, filaments 3-7 mm long, anthers $2-3 \times 1-1.8 \mathrm{~mm}$, laterals purple to blue, medial yellow; staminode subequal, medial staminode present, antherodes 1-2 × 1-2 $\mathrm{mm}$, yellow; ovary $0.9-1.7 \times 1-1.2 \mathrm{~mm}$, minutely pilose, style 1.2-1.4 cm long, stigma truncate. Capsules 4-6 × 3-5 mm, tan-colored when mature, sparsely minutely pilose. Seeds $1.5-2 \times 0.8-1.2$ $\mathrm{mm}$, testa shallowly reticulate, black, lacking a lateral appendage; hilum linear; embryotega lateral. Specimens examined: Águia Branca, Parque Natural Municipal Recanto do Jacaré, 15.V.2004, fl., H.Q. Boudet Fernandes 3332 (MBML); 16.V.2004, fl., H.Q. Boudet Fernandes 3355 (MBML); 16.V.2004, fl., H.Q. Boudet Fernandes 3349 (MBML). Anchieta, 20.V.1988, fl., J.M.L. Gomes 617 (VIES). Cachoeiro de Itapemirim, fazenda do Ouvidor, 14.XI.2017, fl., Q.S. Moraes 279 (VIES). Colatina, Cascatinha do Pancas, 16.VII.2008, fl., A.M. Assis 1727 (MBML). Conceição da Barra, Parque Estadual de Itaúnas, trilha da Alméscar, 3.IV.2017, fl. and fr., Q.S. Moraes 156(VIES); 3.IV.2017, fl., Q.S. Moraes 160 (RB); 19.VI.2015, fl., B.G. Sossai \& Q.S. Moraes 34 (VIES); 8.VIII.2013, fl. and fr., W.O. Souza et al. 153 (VIES). Nova Venécia, APA Pedra do Elefante, 9.V.2008, fl., A.M. Amorim 7399 (MBML); trilha da gameleira, 20.III.2017, fl. and fr., Q.S. Moraes 150 (VIES); serra de baixo, mata do fuxico, 14.IV.2009, fl., R.C. Forzza 5507 (MBML). Pancas, rodovia Colatina-Pancas, 9.XII.1988, fl., H.Q. Boudet Fernandes 2662 (MBML). Santa Maria de Jetibá, 5.IV.2017, fl., L. Kollmann 13350 (MBML). Santa Teresa, Reserva Biológica Augusto Ruschi, 7.V.2003, fl., R.R. Vervloet 2377 (MBML). Serra, Mestre Álvaro, 21.V.2010, fl., R.M. Botelho et al. 56 (VIES). Vitória, 19.IV.1985, O.J. Pereira 440 (VIES); Morro do Guarujá, praia do canto, 4.IX.1984, fl., A.G. da Silva 466 (VIES).

Commelina benghalensis is distributed from tropical and subtropical regions of the world (Pellegrini \& Forzza 2017) (Fig. 3). It is an annual species, and a great deal of morphological variation can be observed, mainly in the indumentum (varying from sparse to dense trichomes) and leafblade size. Despite its morphological variation, it presents diagnostic features like the broadly ovate to obovate leaf-blades and the cleistogamous subterraneous flowers. According to Beentje \& Lansdown (2018), it has had its conservation status assessed as "Least Concern" - LC. Flowers and fruits were recorded throughout the year.

3.2. Commelina diffusa Burm. f., Fl. Ind. (N.L. Burman): 18, t. 7, f. 2. 1768 . Figs. 6b-c; 7

Herbs $20-40 \mathrm{~cm}$ tall, annual, terrestrial, paludal or aquatic. Stems branched, glabrescent, trichomes hyaline. Leaf-sheaths $1.3-1.7 \mathrm{~cm}$ long, hirsute, margins ciliate, upright; pseudopetiole 2-3 $\mathrm{mm}$ long, hirsute, trichomes hyaline to light brown; blades $3.5-10 \times 0.9-2 \mathrm{~cm}$, elliptic to lanceolate, concolorous, green, sparsely sericeous on both sides, base symmetric, cuneate, apex acute. Inflorescence axillary and leaf-opposed, patent to slightly pendulous; peduncle $1.4-2.5 \mathrm{~cm}$ long; spathe $1.1-1.7 \times 0.9-1.3 \mathrm{~cm}$, cordate, green, glabrescent to sparsely hirsutulous, base free, apex acuminate; upper cincinnus 1-3-flowered, exserted, lower cincinnus 3-5-flowered. Flowers chasmogamous, cleistogamous absent, bisexual or staminate; pedicels $0.3-1.5 \mathrm{~cm}$ long, glabrous; upper sepal 3.7-4 × 1.5-2 mm, cymbiform, white, glabrous, lower sepals 4-4.2 × 2.3-3.3 mm, orbicular, free, white, glabrous; paired petals 4-6.8 $\times 2.5-4.3 \mathrm{~mm}$, reniform to rhomboid, blue to lilac, medial petal $4.7-5 \times 3-4.5 \mathrm{~mm}$, shortly-clawed, reniform to orbicular, blue to lilac, similar to the paired petals; medial stamen smaller than the lateral, filaments 3-4 mm long, anthers 0.5-0.7 $\times$ 0.3-0.4 mm, purple to blue; staminodes subequal, medial staminode present, antherodes 0.7-1.2 $\times$ $0.7-8.8 \mathrm{~mm}$, yellow; ovary 0.9-1.1 ×0.5-0.8 mm, glabrous, style $2.8-4 \mathrm{~mm}$ long, stigma capitate. Capsules 7.6-9.1 × 3.8-4.7 mm, tan-colored when mature, glabrous. Seeds 4-4.6 $\times 2.2-3.9 \mathrm{~mm}$, testa double reticulate, dark brown, lacking a lateral appendage; hilum linear; embryotega lateral.

Specimens examined: Cachoeiro de Itapemirim, Burarama, 14.XI.2017, fl., Q.S. Moraes 280 (VIES). Linhares, 7.I.1993, fl., D.A. Folli 1787 (CVRD). Santa Maria de Jetibá, Rio Nove, 19.XII.2007, fl., L. Kollmann 10207 (MBML). Santa Teresa, loteamento Jardim da Montanha, 23.X.1985, fl., W. Boone 833 (MBML, MO); Rio Saltinho, 31.V.1984, fl., W.A. Hoffmann 128 (MBML); próximo à Fazenda Club, 9.IV.1984, fl., J.M. Vimercat 26 (MBML). Vitória, Parque Estadual da Fonte Grande, 26.II.2014, fl., G.N. Martins 31 (VIES). Vila Velha, 28.VI.1984, fl., B. Weinberg (VIES 439).

Commelina diffusa is found in the tropical and subtropical regions of the world, being very common in shady disturbed areas such as roadsides, gardens, forest margins, and agricultural fields 

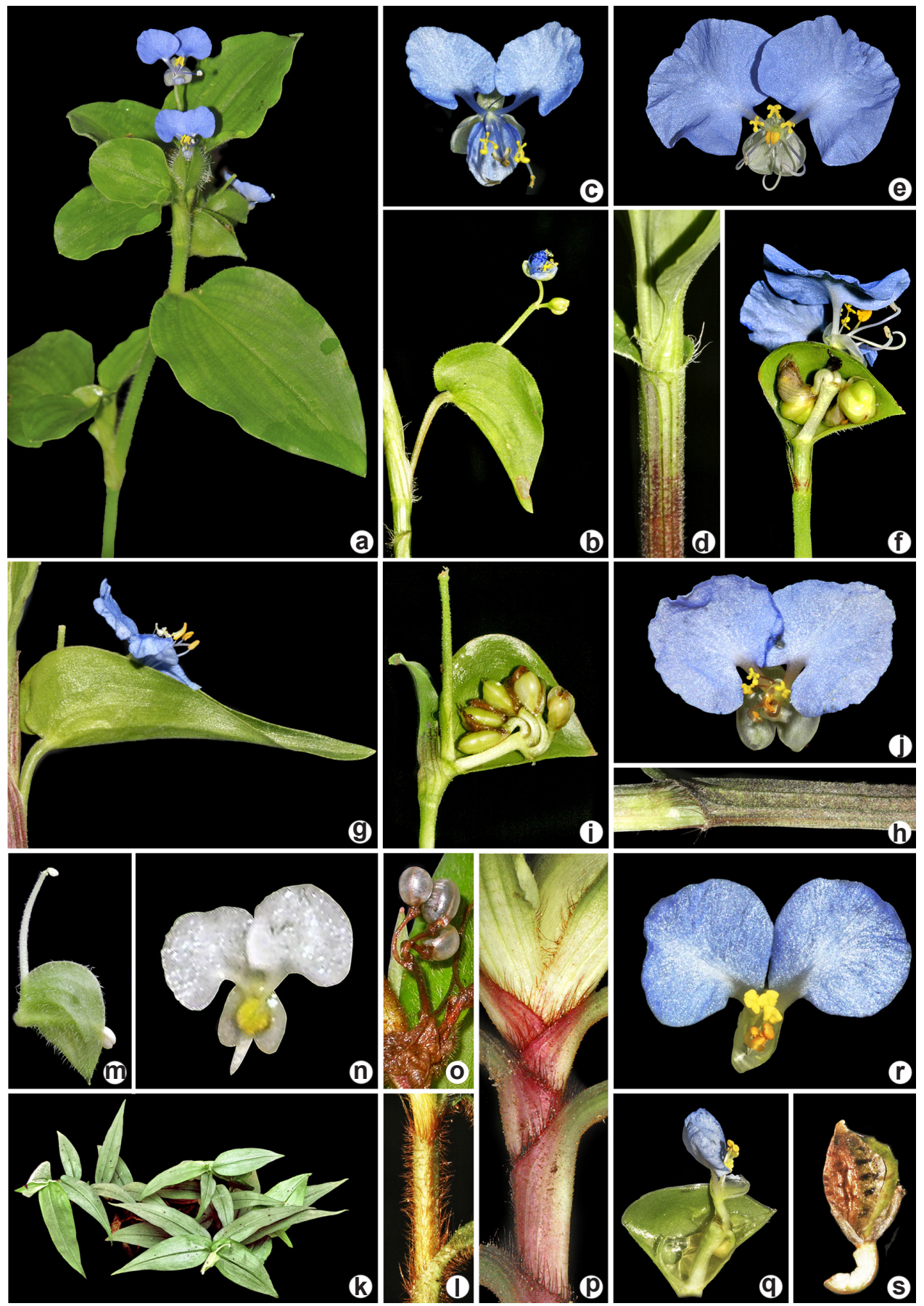

Figure 6 - a-s. Commelina from the state of Espírito Santo, Brazil - a. C. benghalensis - habit; b-c. C. diffusa - b. detail of basal bract spathaceous and inflorescence; $c$. front view of a bisexual flower; $d-f$. C. erecta $-\mathrm{d}$. detail of stem with leaf-sheaths auriculate; e. detail of basal bract spathaceous and inflorescence; f. front view of a bisexual flower; g. C. longicaulis - detail of basal bract spathaceous and inflorescence; h-j. C. robusta - h. detail of leaf-sheaths; i. detail of basal bract spathaceous and inflorescence; j. front view of a bisexual flower; k-o. C. rufipes - k. habit; 1 . detail of stem with trichomes rusty to rusty-brown; $m$. detail of basal bract spathaceous; $n$. front view of bisexual flower; o. capsules; p-s. C. scabrata - p. detail of leaf-sheaths; q. detail of basal bract spathaceous and inflorescence; r. front view of bisexual flower; s. capsules. (Photos: a. CN Fraga; b-j, l, p-s. MOO Pellegrini; k, m. ME Engels; $n$. R Westerduijn; o. IM Coronado-González). 
(Pellegrini \& Forzza 2017). In Brazil, it is widely distributed in all regions (Aona et al. 2020). It is an annual species, which can be diagnosed by its mainly axillary and long pedunculate inflorescences (up to $2.5 \mathrm{~cm}$ ), spathes free at base, similar petals, and shortly-clawed medial petal. According to Lansdown (2018), it has had its conservation status assessed as "Least Concern" - LC. Flowers were recorded throughout the year.

\subsection{Commelina erecta L., Sp. Pl. 1: 41. 1753.}

Figs. 5n-p; 6d-f; 7

Herbs 30-80 cm tall., annual, rupicolous or terrestrial, rarely epiphytic. Stems branched, glabrescent, trichomes hyaline. Leaf-sheaths 0.8-2 cm long, pubescent, margins setose, auriculate; pseudopetiole 1-3 $\mathrm{mm}$ long, glabrescent to hirsute, trichomes hyaline; blades $2.5-10 \times 1.5-4$ $\mathrm{cm}$, elliptic to lanceolate, concolorous, green, glabrescent to puberulous on both sides, base symmetric, round to acuminate, apex acute to acuminate. Inflorescence apparently terminal, erect; peduncle 3-5 mm long; spathe 1-3.5 × 1.6-2.8 cm, depressed ovate to subcordate, green, glabrescent to hirsute, base connate, remaining connate in fruit, apex acute; upper cincinnus aborted, lower cincinnus 2-4-flowered. Flowers chasmogamous, cleistogamous absent, bisexual, rarely staminate; pedicels 3-9 mm long, glabrous; upper sepal 3-4.5 $\times 2.7-3 \mathrm{~mm}$, ovate, white to light green, glabrous, lower sepals 4-9 × 4.5-6 $\mathrm{mm}$, cymbiform, completely connate, white, glabrous; paired petals 1-2 × 0.9-1.8 cm, reniform, blue, sometimes lilac, rarely white, medial petal $2.3-4 \times 1-1.5 \mathrm{~mm}$, sessile, spathulate, hyaline; medial stamen smaller than the lateral, filaments 5-9 mm long, anthers $1.8-3 \times 0.6-1.5 \mathrm{~mm}$, the medial yellow, the lateral grey to greyish-blue; staminodes subequal, medial staminode present, antherodes 1-2 × 0.9-1.1 mm, yellow; ovary 0.9-1.2 ×0.8-1 mm, glabrous, style 1.2-1.5 cm long, stigma trilobate. Capsules 3-5 $\times$ 3-4 mm, tan-colored when mature, glabrous. Seeds $1.7-2.2 \times 0.8-1 \mathrm{~mm}$, testa shallowly foveolate, dark brown, with a lateral, fleshy appendage; hilum linear; embryotega semilateral.

Specimens examined: Águia Branca, Santa Luzia, propriedade Ciro Ferreira, 20. XII.2007, fl. and fr., $V$. Demuner 4827 (MBML). Água Doce do Norte, lado da pedreira, 8.VIII.2017, fl., Q.S. Moraes 212 (VIES). Conceição da Barra, Parque Estadual de Itaúnas, trilha do Buraco do Bicho, 10.IV.2013, fr., J.O. Machado 72 (VIES); alagado próximo à estrada para Itaúnas, 12.II.2014, J.O. Machado 204 (VIES); trilha beira rio, 20.VI.2015, fl., Q.S. Moraes 133 (VIES); trilha da Alméscar, 3.IV.2017, fl., Q.S. Moraes 157 (VIES). Guarapari, Parque Estadual Paulo Cesar Vinha, 5.VIII.2015, fl., A.C.S. Dal col 436 (VIES); 2.II.2013, fl., D.T. Iglesias 101 (VIES); Parque Natural Municipal Morro da Pescaria, 15.VI.2013, fl., A.C.S. Dal col 64 (VIES); afloramento rochoso entre Peracanga e Bacutia, 24.V.2015, fl., A.C.S. Dal col 318 (VIES); Ilha da Guararema, 11.VIII.1996, fl., J.M.L. Gomes 2175 (VIES); 3.V.1994, fl., J.M.L. Gomes 2085 (VIES); Três Ilhas, 13.III.1997, fl., J.M.L. Gomes 2291 (VIES). Linhares, Pontal do Ipiranga, 1.XI.2010, fl., M.C.F. Jesus 364 (VIES); 20.VI.1996, fl., R.L.D. Souza 13 (VIES); Reserva Natural Vale, 6.I.1993, fl., D.A. Folli 1767 (CVRD, RB); estrada Flamengo, 6.IV.1996, fl., D.A. Folli 2739 (CVRD, RB). Nova Venécia, Serra de Baixo, morro lado direito na estrada para a Pedra do Elefante, 14.I.2009, fl., A.P. Fontana 5778 (MBML, RB); Fazenda Nebilna, 15.I.2009, fr., P.H. Labiak 5134 (MBML, RB); 18.VI.2015, fl., N.T.L. Pena 274 (VIES). Pinheiros, Reserva Biológica Córrego do Veado, 15.V.2017, fl., Q.S. Moraes \& R.N. Amaral 168(VIES). Piúma, 10.IV.2010, fl., F.L. Santos 109 (MBML); Ilha do Francês, VII.2002, fl., H. Pinheiro 11 (VIES); 24.X.2002, fl. and fr., $H$. Pinheiro 32 (VIES). Santa Teresa, 6.IX.2012, fl., L. Kollmann 12437 (MBML); São João de Petrópolis, Valão de São Brás, 6.II.2013, fl., V.B. Sarnaglia Jr. 645 (RB); estrada para o 25 de julho, 3.XII.1998, fl., L. Kollmann 1198 (MBML). Viana, 25.VIII.1987, fl., J.M.L. Gomes 113 (VIES). Vila Velha, Interlagos, 1.IX.2007, fl., F.B.C. Souza 49 (VIES); Alagados do Vale, 1.IX.2014, fl., R.T. Valadares 1272 (VIES); Morada do Sol, 26.III.2006, fl., P.F. Souza 136 (MBML).

Commelina erecta is distributed in the tropical and subtropical regions of the world (Pellegrini \& Forzza 2017). It occurs in almost all

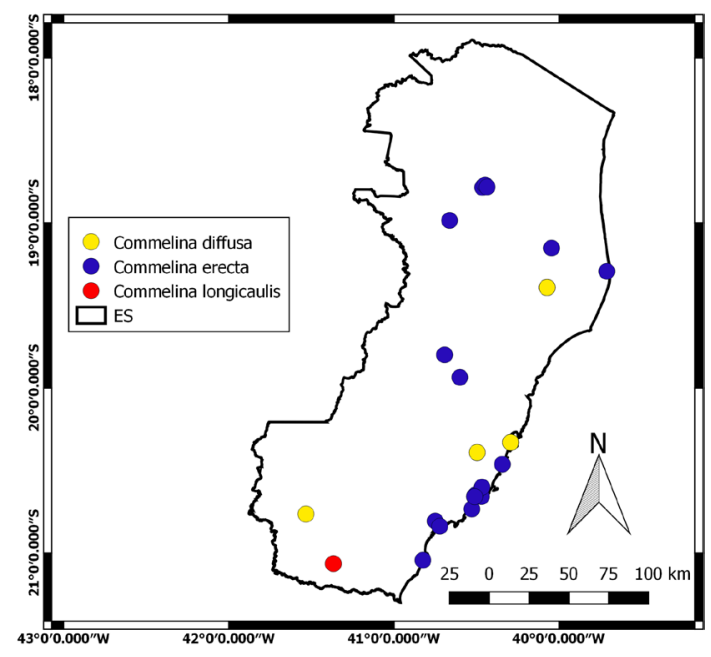

Figure 7 - Geographic distribution of Commelina diffusa, C. erecta, C. longicaulis in the state of Espírito Santo. 
Brazilian states, except Acre, Roraima, Amapá states (Aona et al. 2020). It is an annual species, and a great deal of morphological variation can be observed, mainly in its indumentum (varying from sparse to dense trichomes). Despite this morphological variation, it is recognized by its mainly leaf-sheaths with auriculate margin, aborted upper cincinnus, lower sepals cymbiform, medial petal hyaline, and seeds with a lateral and fleshy appendage. According to Ghogue \& Kumar (2020), it has had its conservation status assessed as "Least Concern" - LC. Flowers and fruits were recorded throughout the year.

3.4. Commelina longicaulis Jacq., Collectanea 3: 234. 1791 . Figs. 5m; 6g; 7

Herbs 20-100 cm tall, annual, terrestrial, paludal or aquatic. Stems branched, hispid, trichomes hyaline. Leaf-sheaths $1-1.4 \mathrm{~cm}$ long, hispid, margins ciliate, upright; sessile; blades $3.3-11.7 \times 0.9-2 \mathrm{~cm}$, narrowly elliptic to narrowly lanceolate, concolorous, green, hispid on both sides, base symmetric, cuneate, apex acute. Inflorescence axillary and leaf-opposed, patent to slightly pendulous; peduncle $3-6 \mathrm{~cm}$ long; spathe 1.1-5.6 × 1.2-3 cm, cordate, green, sparsely hispidulous, base free, apex acuminate; upper cincinnus 1-2-flowered, included, lower cincinnus 3-4-flowered. Flowers chasmogamous, cleistogamous absent, bisexual, sometimes staminate; pedicels $1.3-2.5 \mathrm{~cm}$ long, glabrous; upper sepal 2.8-3.5 × 1.7-2.1 mm, cymbiform, white, glabrous, lower sepals 3-3.6 ×2.8-3.1 mm, ovate, free, white, glabrous; paired petals $8-10$ $\times$ 6-7 mm, reniform, blue, medial petal 5-6.3 $\times$ 4-5 mm, shortly-clawed, reniform to orbicular, blue, similar to the paired petals; medial stamen smaller than the lateral, filaments $4.8-6 \mathrm{~mm}$ long, anthers $0.6-1.2 \times 0.4-0.6 \mathrm{~mm}$, yellow; staminodes subequal, medial staminode present, antherodes $0.4-0.8 \times 0.1-0.2 \mathrm{~mm}$, white; ovary $1.8-2.1 \times$ 0.9-1.1 mm, pubescent, style 4-5 mm long, stigma capitate. Capsules not seen. Seeds not seen.

Specimens examined: Mimoso do Sul, pedra dos pontões, 16.XI.2017, fl., Q.S. Moraes 284 (VIES).

Commelina longicaulis is recorded in Brazil from Alagoas, Bahia, Ceará, Pernambuco, Goiás, Mato Grosso do Sul, Mato Grosso, Minas Gerais, Paraná and Santa Catarina (Aona et al. 2020). Newly recorded for Espírito Santo, it is currently only known to occur in Mimoso do Sul, from high elevations and growing in rainforest remnants associated with inselbergs (Fig. 7).
Morphologically similar to $C$. diffusa due to its free spathe base, inflorescence axillary, and medial petal shortly-clawed. It differs by its stature of 20-100 cm tall ( $v s$. up to $40 \mathrm{~cm}$ in C. diffusa), leaves sessile (vs. pseudopetiolate), peduncle longer than $3 \mathrm{~cm}$ (vs. up to $2.5 \mathrm{~cm}$ long), yellow anthers ( $v s$. ochre to brown), white antherodes ( $v s$. yellow), and ovary pubescent (vs. glabrous). The species has not had its conservation assessed yet.

3.5. Commelina robusta Kunth, Enum. Pl. 4: 52. 1843. Figs. 6h-j; 8

Herbs 30-70 cm tall, perennial, rupicolous or terrestrial. Stems branched, scabrid, trichomes sparse, hyaline. Leaf-sheaths $1-3.5 \mathrm{~cm}$ long, scabrid, margins ciliate, trichomes red to dark red to atro-vinaceous, upright; sessile; blades 4-14 × 1.6-3.8 cm, lanceolate to oblanceolate, concolorous, green, scabrid on both sides, base asymmetric, cuneate to cuneate, apex acuminate. Inflorescence terminal, erect; peduncle 0.6-1.4 cm long; spathe $1.4-3.5 \times 2.7-4.2 \mathrm{~cm}$, widely depressed ovate to depressed ovate, green, scabrid, connate up to mid-length, remaining connate in fruit, apex acute to acuminate; upper cincinnus 1-5-flowered, exserted, lower cincinnus 5-7-flowered. Flowers chasmogamous, cleistogamous absent, bisexual or staminate; pedicels $0.5-2.5 \mathrm{~cm}$ long, glabrous; upper sepal 3-4.3 × 1.9-2.3 mm, cymbiform, white, glabrous, lower sepals $1.5-2.4 \times 0.3-0.7 \mathrm{~cm}$, obovate to widely, connate up to mid-length, white, glabrous; paired petals $3-4.5 \times 2.8-4 \mathrm{~cm}$, very widely ovatereniform to depressed ovate-reniform, pale lilac to lilac or light blue to blue, rarely white, medial petal $1.3-1.6 \times 0.5-1.1 \mathrm{~cm}$, sessile, spathulate to obovate, light blue to pale lilac, rarely white; medial stamen smaller than the laterals, filaments $3.7-7.5 \mathrm{~mm}$ long, anthers $1-1.5 \times 0.3-0.6 \mathrm{~mm}$, orange-yellow to orange; staminodes subequal, medial staminode present, antherodes $0.8-1.1 \times$ $0.7-1 \mathrm{~mm}$, yellow; ovary $0.5-0.7 \times 0.6-0.8 \mathrm{~mm}$, glabrous, style $6-7.5 \mathrm{~cm}$ long, stigma trilobate. Capsules 1-1.5 × 0.8-1.5 cm, smooth, tan-colored when mature, glabrous. Seeds 1.8-2.5 × 1.3-1.7 $\mathrm{mm}$, testa foveolate to rugose-foveolate, brown to dark brown, lacking a lateral appendage; hilum linear; embryotega semilateral.

Specimens examined: Águia Branca, propriedade Sr. Voito, 10.VIII.2017, fl., Q.S. Moraes et al. 216 (VIES). Alfredo Chaves, Cachoeira de Matilde, 2.XII.2016, fl., J. Freitas 442 (VIES). Castelo, Parque Estadual do Forno Grande, 12.VI.2004, f1., L. Kollmann 6740 
(MBML); 1.V.2008, fl., C.N. de Fraga 1943 (MBML). Nova Venécia, APA Pedra do Elefante, 5.II.2018, fl., Q.S. Moraes 291 (VIES); 4.III.2018, fl. and fr., Q.S. Moraes 295 (VIES). Santa Maria de Jetibá, Garrafão, Sítio Renascer, 8.II.2009, fl., T.S. Lorencini et al. 192 (VIES); Garrafão, sitio Renascer, 11.X.2008, fl., T.S. Lorencini et al. 73 (VIES). Santa Teresa, Vale dos Colibris, 5.IV.1984, fl., W. Pizziolo 15 (VIES); Valsugana Velha, 10.I.1986, fl., W. Boone 1003 (MBML, $\mathrm{MO})$.

Commelina robusta is distributed from Mexico to Argentina (Pellegrini et al., in press). It occurs in almost all Brazilian states, except for Roraima and Amapá (Aona et al. 2020). Despite the recent reestablishment of $C$. scabrata Seub. and $C$. vestita Seub. (Pellegrini et al., in press), $C$. robusta still presents a great deal of morphological variation in its current circumscription. It can be differentiated from C. scabrata by its leaves scabrid on both sides ( $v s$. adaxially glabrous to sparsely hispid, abaxially hispid to densely hispid, hirsute along the midvein in C. scabrata), the developed upper cincinnus (vs. vestigial in C. scabrata), capsules smooth and tan-colored when mature (vs. verrucate and opaque white), seeds with foveolate to rugose-foveolate testa (vs. smooth), and linear hilum (vs. C-shaped). Commelina robusta has not had its conservation assessed yet. Flowers and fruits were recorded throughout the year.

3.6. Commelina rufipes Seub. in Martius, Fl. bras. 3(1): 265. 1855.

Figs. 6k-0; 8

Herbs 20-40 cm tall, perennial, terrestrial. Stems rarely branched, hirsute, trichomes hyaline or rusty to rusty-brown. Leaf-sheaths $1-1.8$ cm long, hirsute, margins hispid, upright; pseudopetiole 1-2 mm long, hirsute, trichomes rusty to rusty-brown; blades $3.5-12 \times 1-4$ $\mathrm{cm}$, elliptic to lanceolate, concolorous, green, hirsute both sides, base symmetric, cuneate, apex acuminate. Inflorescence terminal, erect; peduncle 3-5 mm long; spathe 1.8-3.5 × 2-3.8 $\mathrm{cm}$, ovate to widely ovate, base connate, splitting open in fruit, apex acute, light green, hispid; upper cincinnus 1-2-flowered, exserted, lower cincinnus 3-4-flowered. Flowers chasmogamous, cleistogamous absent, bisexual, sometimes staminate; pedicels 1-2.3 cm long, glabrous; upper sepal 2.5-3 × 1.5-1.7 mm, cymbiform, white, glabrous, lower sepals 3.5-4.8 $\times 2.5-3 \mathrm{~mm}$, ovate, connate up to mid-length, white, glabrous; paired petals $6-8 \times 5.5-7.5 \mathrm{~mm}$, broadly rhomboid to rhomboid-reniform, white, medial petal 3-4.5 $\times$ 0.7-1.5 mm, sessile, reduced or linear, hyaline or slightly paler than the paired petals; medial stamen smaller than the laterals, filaments $2.5-5 \mathrm{~mm}$ long, anthers $1-2 \times 0.4-0.8 \mathrm{~mm}$, yellow; staminodes subequal, medial staminode aborted, antherodes $0.5-1 \times 0.9-1.2 \mathrm{~mm}$, pale yellow; ovary $1-1.5 \times$ 0.8-1 mm, glabrous, style 3-5 mm long, stigma truncate. Capsules 3.6-5 × 3-4.7 mm, pearly-white to silvery when mature, glabrous. Seeds $2-3 \times$ 3-3.5 mm, testa smooth, brown, lacking a lateral appendage; hilum linear; embryotega semilateral. Specimens examined: Linhares, 30.VI.1993, fl., G.L. Farias 615 (CVRD, SAMES); 20.VI.2000, fl. and fr., D.A. Folli 3637 (CVRD, SAMES).

Commelina rufipes ranges from Mexico to Southeastern Brazil (Aona et al. 2020; Pellegrini \& Forzza 2017). It is a rare species in the Atlantic Forest and Cerrado biomes, with most records concentrated at the Amazon Forest (Pellegrini \& Forzza 2017). In Espírito Santo, it is known exclusively from the "tabuleiro" region Linhares, growing understory in rainforests (Fig. 8). The floral morphology of $C$. rufipes is still poorly understood since it is most commonly collected in fruit. It is easily distinguished from most species of the genus by its hirsute vegetative organs with rusty to rusty-brown trichomes, white flowers, and pearl-like fruits. Commelina rufipes has not had its conservation assessed yet. The information available indicates it flowers in June.

3.7. Commelina scabrata Seub. in Martius, Fl. bras. 3(1): 266.1855.

Figs. 6p-s; 8

Herbs 20-50 cm tall, perennial, rupicolous or terrestrial. Stems branched, pubescent, trichomes sparse, hyaline or rusty-brown. Leaf-sheaths 0.9 $1.7 \mathrm{~cm}$ long, hirsute, margins ciliate, trichomes reddish, upright; pseudopetiole 4-6 mm long, scabrid, trichomes reddish; blades 4.7-13 $\times 1.8-$ $3.2 \mathrm{~cm}$, narrowly oblong to narrowly elliptic, rarely lanceolate to ovate, concolorous, green, adaxially glabrous to sparsely hispid, base asymmetric, cuneate, apex acuminate to long-acuminate. Inflorescence terminal, erect; peduncle $0.5-0.8 \mathrm{~cm}$ long; spathe 3-3.6 × 2.9-4.3 cm, widely triangular to subcordate, green, hispid to hirsute, connate almost to the apex, remaining connate in fruit, apex acute to acuminate; upper cincinnus aborted, included, lower cincinnus 1-2(-3)-flowered. Flowers chasmogamous, cleistogamous absent, bisexual, sometimes staminate; pedicels 0.9-1.4 cm long, glabrous; upper sepal 3.2-4.8 × 1.9-2.6 
cm, cymbiform, white, glabrous, lower sepals $1.2-$ $1.6 \times 0.5-0.6 \mathrm{~cm}$, obovate, connate up to the upper third, white, glabrous; paired petals $2.2-3.5 \times$ $2.3-3.8 \mathrm{~cm}$, very widely ovate to widely depressed ovate, pale lilac to light blue, medial petal 1-1.4 $\times 0.2-0.5 \mathrm{~cm}$, sessile, oblong to spathulate, pale lilac to light blue; medial stamen smaller than the laterals, filaments $3.1-10.3 \mathrm{~mm}$ long, anthers 1.4-1.6 × 1.3-1.5 mm, orange-yellow to orange; staminodes subequal, medial staminode present, antherodes 1.6-1.8 × 1.3-1.6 mm, yellow; ovary $1.6-1.7 \times 1.4-1.6 \mathrm{~mm}$, glabrous, style $1-1.3 \mathrm{~cm}$ long, stigma trilobate. Capsules 1.3-1.6 × 1-1.3 $\mathrm{cm}$, opaque white, glabrous. Seeds $1-1.4 \times 0.4-0.5$ $\mathrm{mm}$, testa echinate, brown, lacking a lateral appendage; hilum C-shaped; embryotega lateral. Specimens examined: Linhares, Reserva Natural da Vale do Rio Doce, estrada da Gávea, 15.IV.1999, fl. and fr., D.A. Folli 3395 (CVRD, HURB, SAMES). Santa Maria de Jetibá, terreno de R. Berger, 3.IV.2003, fl. and fr., L. Kollmann et al. 6077 (MBML). Santa Teresa, Instituto Mello Leitão, pátio do MBML, 3.VI.1985, fl. and fr., H.Q. Boudet Fernandes 1201 (MBML, US); caminho para o Sítio do Dr. Pedro, 10.V.1984, fl. and fr., J. Vimercat 110 (MBML, US); Estação Biológica de Santa Lúcia, 20.VIII.1985, fl., W. Boone 695 (MBML); trilha para o túmulo de Augusto Ruschi, ao lado da ponte José Molina, 26.VI.2012, fl. and fr., M.O.O. Pellegrini et al. 248 (RB, VIES).

Commelina scabrata is endemic to Brazil, recorded for the states of Espírito Santo (Fig. 8), Rio de Janeiro, and São Paulo (Pellegrini et al., in press). Until recently treated as a synonym

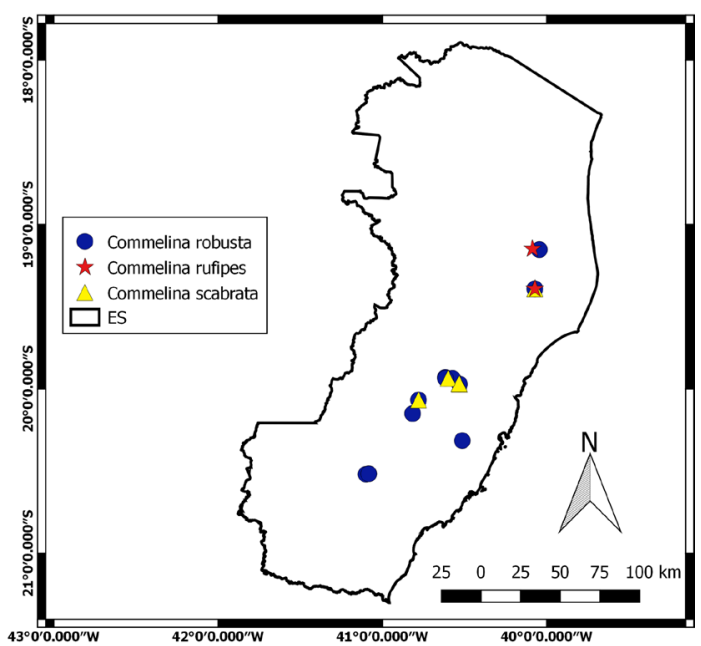

Figure 8 - Geographic distribution of Commelina robusta, C. rufipes, C. scabrata in the state of Espírito Santo. of $C$. robusta, it can be easily differentiated by its aborted and included upper cincinnus ( $v s$. developed and exserted), fruits opaque white when mature (vs. tan-colored), seeds with echinate testa (vs. foveolate to rugose-foveolate), and hilum C-shaped (vs. linear). According to Pellegrini et al. (in press), it should be regarded as Endangered (EN). Flowers and fruits were recorded from April to August.

4. Dichorisandra J.C.Mikan, Del. fl. faun. bras. 1: 1, t.3. 1820 .

Herbs perennial, rupicolous or terrestrial, rarely epiphytic, rhizomatous. Roots fibrous with ellipsoid to fusiform tubers at apex. Stems erect, ascending, scrambling, vining, rarely decumbent, branched or unbranched, monomorphic when flowering. Leaves distichously or spirallyalternate, sessile or pseudopetiolate. Inflorescences terminal, axillary or basal, sessile or pedunculate, erect, patent or pendulous; basal bract bracteose or leaf-like; cincinni many, alternate, free, sessile or pedunculate, many-flowered; cincinnus bract bracteose, rarely leaf-like; bracteoles flat, scarious. Flowers zygomorphic or actinomorphic, bisexual or staminate; hook-trichomes absent; sepals subequal; petals subequal, dark blue, blue, light blue, bluish-purple, purple or lilac, rarely white; stamens 5-6, homomorphic, subequal or dimorphic, filaments glabrous, anthers introrsely rimose (but functionally poricidal) or truly poricidal dehiscing by one or two apical pores; anthers sacs parallel, elongate, 3 to 4 times longer than the filaments; connectives inconspicuous; ovary 3-locular, globose, style straight or curved, stigma capitate or truncate. Capsules globose, cylindric or ellipsoid, thick-walled. Seeds arillate, aril opaque or hyaline, colorless, white or orange, testa scrobiculate or foveolate; hilum C-shaped; embryotega semidorsal or semilateral, concolorous with the testa.

Dichorisandra is one of the largest genera of Commelinaceae (ca. 60 species), with a Neotropical distribution and most of its species confined to the Atlantic Forest domain (Faden \& Hunt 1991; Evans et al. 2003; Aona 2008). In Brazil, 43 species are recorded (Aona et al. 2020). The genus is characterized by five to 6 stamens, parallel anther sacs that are elongate and three to four times longer than the filaments, poricidal or introrsely rimose (but functionally poricidal) anthers, and arillate seeds (Aona 2008; Pellegrini \& Faden 2017). 


\section{Key to the species of Dichorisandra of the state of Espírito Santo}

1. Leaves completely green or with brown to reddish-brown variegation abaxially; inflorescences axillary or basal, perforating the leaf-sheath; petals white, stamens dimorphic (the posterior with large and connivent anthers, the anterior with small and free anthers)

2. Stems pubescent; inflorescences basal; stamens 6 , all anthers poricidal

4.17. Dichorisandra sp.

2'. Stems glabrous; inflorescences lateral; stamens 5-6, all anthers introrsely rimose (but functionally poricidal)

4.8. Dichorisandra neglecta

1'. Leaves green completely, sometimes with silver stripes or small white variegation; inflorescences terminal, not perforating the leaf-sheath; petals dark blue, blue, light blue, bluish-purple, purple or lilac, rarely white; stamens homomorphic or slightly heteromorphic

3. Stems branched throughout, ascending, scrambling, vining or decumbent; leaves distichouslyalternate, base asymmetric .

4. Inflorescences patent or pendulous; stamens 5(-6), anthers introrsely rimose (but functionally poricidal); aril white.

5. Inflorescences sparsely shortly-pilose (becoming glabrous at age); petals evenly colored, anthers yellow; capsules straight.

6. Stems vining; flowers actinomorphic, petals pale blue to lilac

4.4. Dichorisandra glabrescens

6'. Stems scrambling or ascending with decumbent apex; flowers zygomorphic, petals white

4.7. Dichorisandra incurva

5'. Inflorescences hispidulous to densely velutine; petals lilac to purple with a white basal third, anthers pale yellow or white to cream with purple to pink apex; capsules curved

7. Leaves sparsely glabrous to hispidulous on both sides; inflorescences pendulous; anthers white to cream with the upper half or third purple

4.11. Dichorisandra penduliflora

7'. Leaves velutine on both sides, sometimes glabrescent; inflorescences ascending to patent or pendulous; anthers pale yellow.

4.16. Dichorisandra velutina

4'. Inflorescences erect, rarely ascending; stamens 6, anthers poricidal; aril orange. .8

8. Leaf-blades evenly pubescent on both sides; sepals densely pilose; capsules ellipsoid.

4.13. Dichorisandra pubescens

8'. Leaf-blades unevenly pubescent, with trichomes denser abaxially; sepals glabrous to sparsely pilose along the midvein or sericeous; capsules globose to subglobose......... 9

9. Stems erect, sericeous; leaf-blades abaxially densely pilose, congested along the veins; capsules green, smooth . 4.15. Dichorisandra tejucensis

9'. Stems ascending, scrambling or vining, glabrous to sparsely pilose; leaf-blades abaxially glabrous to sparsely pilose, when present congested at the base or along the midvein; capsules green with an atro-vinaceous apex, smooth with a verrucose apex 4.6. Dichorisandra hexandra

3'. Stems unbranched or branched at base or branched in the upper third, erect; leaves spirally-alternate, base symmetric

10. Stems unbranched or branched at base; flowers actinomorphic, style straight; aril hyaline, colorless, embryotega semilateral.

11. Leaves sparsely velutine on both sides; inflorescence pendulous, main axis developed

4.9. Dichorisandra nutabilis

11'. Leaves adaxially glabrous, abaxially sericeous or sparsely setose; inflorescence erect, main axis inconspicuous

12. Young leaves light green sometimes vinaceous, mature leaves membranous; sepals glabrous, rarely sparsely setose at base; filaments free; anthers dehiscent through two apical pores; stigma truncate 4.1. Dichorisandra acaulis 
12'. Young leaves pink to brownish-mauve, mature leaves chartaceous; sepals sparsely sericeous; filaments basally connate; anthers dehiscent through one apical pore; stigma slightly trilobate ... 4.3. Dichorisandra forzzae

10'. Stems branched on the upper third; flowers zygomorphic, style curved; aril opaque or slightly hyaline, white, embryotega semidorsal or rare semilateral

13. Leaf-blades densely hirsute; anthers white with purple to pink apex, ovary hirsute or glandularpubescent...... 14

14. Leaf-blades adaxially dark green with longitudinal silver stripes, abaxially vinaceous to purple; inflorescence, peduncle, pedicels, sepals and ovary hirsute; capsules globose; seeds 1-2 per locule, testa light brown to reddish-brown.

4.2. Dichorisandra aonae

14'. Leaf-blades adaxially green, abaxially light green; inflorescence, peduncle, pedicels, sepals and ovary glandular-pubescent; capsules ellipsoid; seeds 3-6 per locule, testa dark brow....

4.5. Dichorisandra glandulosa

13'. Leaf-blades glabrous or hirsutulous; anthers yellow, ovary glabrous

15. Stamens 6,4 pointing to the center of the flower and 2 pointing outwards, anthers poricidal (dehiscent by two apical pores).

4.12. Dichorisandra procera

15'. Stamens 5(-6), all pointing up, anthers introrsely rimose (but functionally poricidal) ...... 16

16. Plants robust, up to $3 \mathrm{~m}$ tall, leaves glabrous, stripes absent; capsules globose.

4.10. Dichorisandra paranaensis

16'. Plants delicate, smaller than $60 \mathrm{~cm}$ tall, leaves hirsutulous, small and discontinuous longitudinal stripes present; capsules ellipsoid 4.14. Dichorisandra striatula

4.1. Dichorisandra acaulis Cogn., Ill. Hort. 41:297, pl. 19. 1894.

Figs. 9; 10a-c

Herbs $20-50 \mathrm{~cm}$ tall., terrestrial. Stems erect, unbranched, setose, trichomes hyaline. Leaves spirally-alternate; sheaths 1-2 cm long, sparsely setose, margins setose, trichomes hyaline; pseudopetiole $0.5-2 \mathrm{~cm}$ long, setose, trichomes hyaline; blades $10-35 \times 3.2-17 \mathrm{~cm}$, ovate to obovate, membranous mature leaves, adaxially dark green, glabrous, abaxially light green, sometimes vinaceous in young leaves, sparsely setose, trichomes hyaline, base symmetric, cuneate to round, apex acuminate. Inflorescence terminal, erect, not perforating the leaf-sheath; main axis inconspicuous, peduncle 4 mm long; cincinni 3-5, 2-4-flowered; cincinnus bract 5-20 × 2-5 mm, lanceolate, green, glabrous; bracteoles 2-4 mm long, deltoid, brown, glabrescent. Flowers actinomorphic; pedicels 2-4 cm long, glabrous; sepals $1-1.7 \times 0.3-0.6 \mathrm{~cm}$, ovate to oblong, green, glabrous, rarely sparsely setose at base; petals $1-1.8 \times 0.5-0.7 \mathrm{~cm}$, ovate to elliptic to oblanceolate, bluish-purple to purple, basal third white; stamens 6 , homomorphic, filaments 2-4 mm long, free; anthers 4-6 mm long, poricidal, dehiscent through two apical pores, white, purple at apex; ovary $2-2.3 \times$ 2-2.2 mm, setose, style 4-6 mm long, straight, white at base, purple at apex, stigma truncate. Capsules $2.1-3 \times 0.5-0.6 \mathrm{~cm}$, cylindric, green when immature, brown when mature, smooth, sparsely setose. Seeds $4.3-5 \times 2-2.5 \mathrm{~mm}$, dark brown to black, testa scrobiculate, hilum $\mathrm{C}$-shaped, embryotega semilateral, aril slightly hyaline, colorless, spongy. Specimens examined: Águia Branca, Águas Claras, propriedade Sr. Voito, 2.II.2006, fl., L.F.S. Magnago 676 (MBML). Linhares, 17.I.1994, fl., D.A. Folli 2173 (CVRD). Marilândia, Alto Liberdade, propriedade Deuclecio Lorenzini, 19.IV.2006, fl., L.F.S. Magnago 906 (MBML). Santa Leopoldina, Colina Verde, Morro do Agudo, arredores do Morro do Agudo, lado direito do bananal, 16.IV.2013, fl. and fr., M.O.O. Pellegrini et al. 328 (NY, RB); Fazenda Caioaba, propriedade Virloni, trilha do córrego Caioaba, 5.I.2006, fl., L.F.S. Magnago 472 (MBML); California, propriedade Albertino Kriger, 16.III.2007, fl., A.P. Fontana 3046 (MBML, RB). São Roque do Canaã, Misterioso, 24.XII.2003, fl., R.R. Vervloet 2587 (MBML); A. Castellanos 26500 (CEPEC); A. Castellanos 26605 (CEPEC).

Dichorisandra acaulis is endemic to the state of Espírito Santo (Fig. 9), growing understory in rainforests (Aona et al. 2020). Characterized mainly by its peduncle inconspicuous (up to $4 \mathrm{~mm}$ long) inflorescences, pedicels up to $4 \mathrm{~cm}$ long, and anthers dehiscent through two apical pores. Dichorisandra acaulis has had its conservation status assessed as "Endangered" - EN (CNCFlora 2012a; MMA 2014). Flowers and fruits were recorded from December to April. 
4.2. Dichorisandra aonae M.Pell. \& Q.Moraes, sp. nov. Type: BRAZIL. ESPÍRITO SANTO: Água Doce do Norte, mata secundária próximo ao afloramento da torre de celular, 16.III.2018, fl. and fr., Q.S. Moraes 239 (holotype: VIES).

Figs. 9; 11; 12h-o

Dichorisandra aonae sp. nov. is characterized by its vegetative organs, inflorescences, pedicels, sepals, ovary and capsules hirsute to densely hirsute with hyaline to light brown trichomes, leaf-blades strongly discolorous, five stamens, anthers introrsely rimose but functionally poricidal, white with upper half or third bluish-purple to purple, globose capsules, and 1-2 seeds per locule.

Herbs $20-50 \mathrm{~cm}$ tall, terrestrial. Stems erect, branched, internodes $0.5-7.2 \mathrm{~cm}$ long, vinaceous to brown, hirsute, trichomes hyaline to light brown. Leaves spirally-alternate, congested at the apex of the stem; sheaths $0.7-1.8 \mathrm{~cm}$ long, green, hirsute to densely hirsute, margins hirsute, trichomes hyaline to light brown; pseudopetiole 3-7 mm long, canaliculate, hirsute, trichomes hyaline to light brown; blades $13-18 \times 3.5-5.3 \mathrm{~cm}$, elliptic to oblanceolate, slightly succulent, discolorous, adaxially dark green, with longitudinal silver stripes, abaxially vinaceous to purple, densely hirsute in both sides, base symmetric, cuneate, margins hirsute, apex acuminate, trichomes hyaline to light brown; primary vein conspicuous adaxially, impressed, light green, prominent abaxially, obtuse; secondary veins 3-4 pairs, slightly conspicuous on both sides, becoming more evident upon drying. Inflorescence

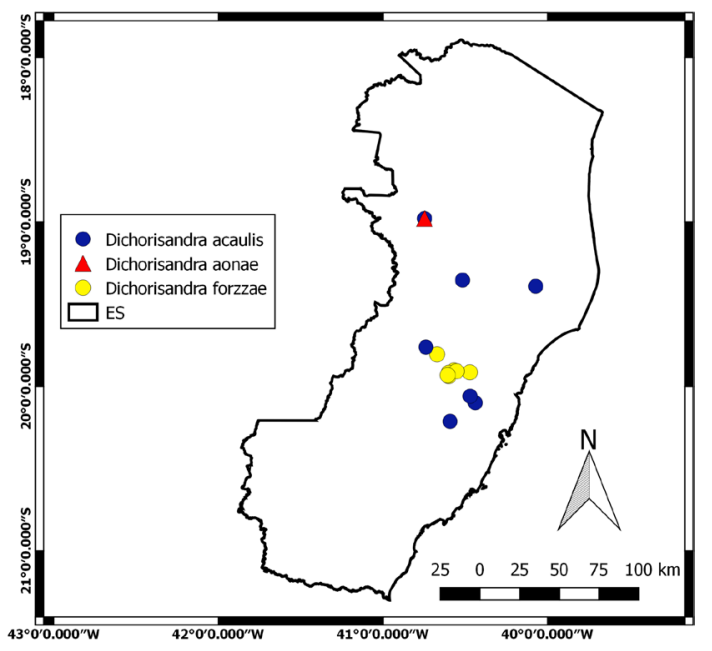

Figure 9 - Geographic distribution of Dichorisandra acaulis, D. aonae, D. forzzae in the state of Espírito Santo. terminal, erect, not perforating the leaf-sheath; basal bract $0.5-1.6 \times 0.2-0.4 \mathrm{~cm}$, bracteose, linearlanceolate to lanceolate, green, hirsute, trichomes hyaline to light brown; peduncle 4-9 $\mathrm{mm}$ long, brownish-green to green, hirsute, trichomes hyaline to light brown; main axis inconspicuous, green, hirsute, trichomes hyaline to light brown; cincinni 3-5, alternate, 3-4-flowered, peduncle inconspicuous; cincinnus bracts $0.3-1 \times 0.1-0.2$ $\mathrm{cm}$, lanceolate, green, hirsute, trichomes hyaline to light brown, apex acuminate; bracteoles 2-6 $\mathrm{mm}$ long, deltoid, green, hirsute, trichomes hyaline to light brown. Flowers bisexual or staminate, zygomorphic, $2.2-3.3 \mathrm{~cm}$ diam; pedicels $3-4 \mathrm{~mm}$ long, green, hirsute, trichomes hyaline; floral buds $0.6-1.1 \times 0.2-0.6 \mathrm{~cm}$, green, apex lilac, ovoid; sepals $0.9-1.2 \times 0.3-0.5 \mathrm{~cm}$, ovate, membranous, green, apex lilac to purple, hirsute, trichomes hyaline, margins glabrous; petals $1.3-1.7 \times 1.4-1.6 \mathrm{~cm}$, rhomboid to very widely obovate, bluish-purple to purple, basal third white; stamens 5, subequal, all pointing up; filaments $2-3 \mathrm{~mm}$ long, anthers 3-4 mm long, rimose (but functionality poricidal), white, upper half or third bluish-purple to purple; upper medial staminode absent; ovary 1.7-2.5 × 1-2 $\mathrm{mm}$, subglobose, hirsute, trichomes hyaline to light brown, style $3.7-4 \mathrm{~mm}$ long, curved, base white, bluish-purple to purple at apex, stigma truncate, purple. Capsules $0.8-1 \times 0.7-0.9 \mathrm{~cm}$, globose, green when immature, dark brown when mature, smooth, hirsute, trichomes hyaline to light brown. Seeds $1-2$ per locule, $5-7 \times 1.8-2.3 \mathrm{~mm}$, ellipsoid to triangular; testa scrobiculate, light brown to reddishbrown; hilum C-shaped; embryotega semidorsal, aril opaque, white, thick, spongy.

Specimens examined (paratype): Água Doce do Norte, torre de celular, mata secundária ao longo da subida, 22.IV.2013, fl., M.O.O. Pellegrini et al. 370 (RB). Barra de São Francisco, Parque Municipal Sombra da Tarde, 21.XI.2000, fl., L. Kollmann et al. 3336 (MBML).

The specific epithet honors Dr. Lidyanne Yuriko Saleme Aona (Universidade Federal do Recôncavo da Bahia) for her contributions to the taxonomy of Dichorisandra.

Dichorisandra aonae is endemic to the municipality of Água Doce do Norte (Espírito Santo), growing in rainforest remnants associated with inselbergs, in humid and shaded places (Fig. 9). It is characterized by its vegetative organs, inflorescences, pedicels, sepals, ovary and capsules hirsute to densely hirsute with hyaline to light brown trichomes, leaf-blades strongly discolorous (adaxially dark green with silver stripes and 

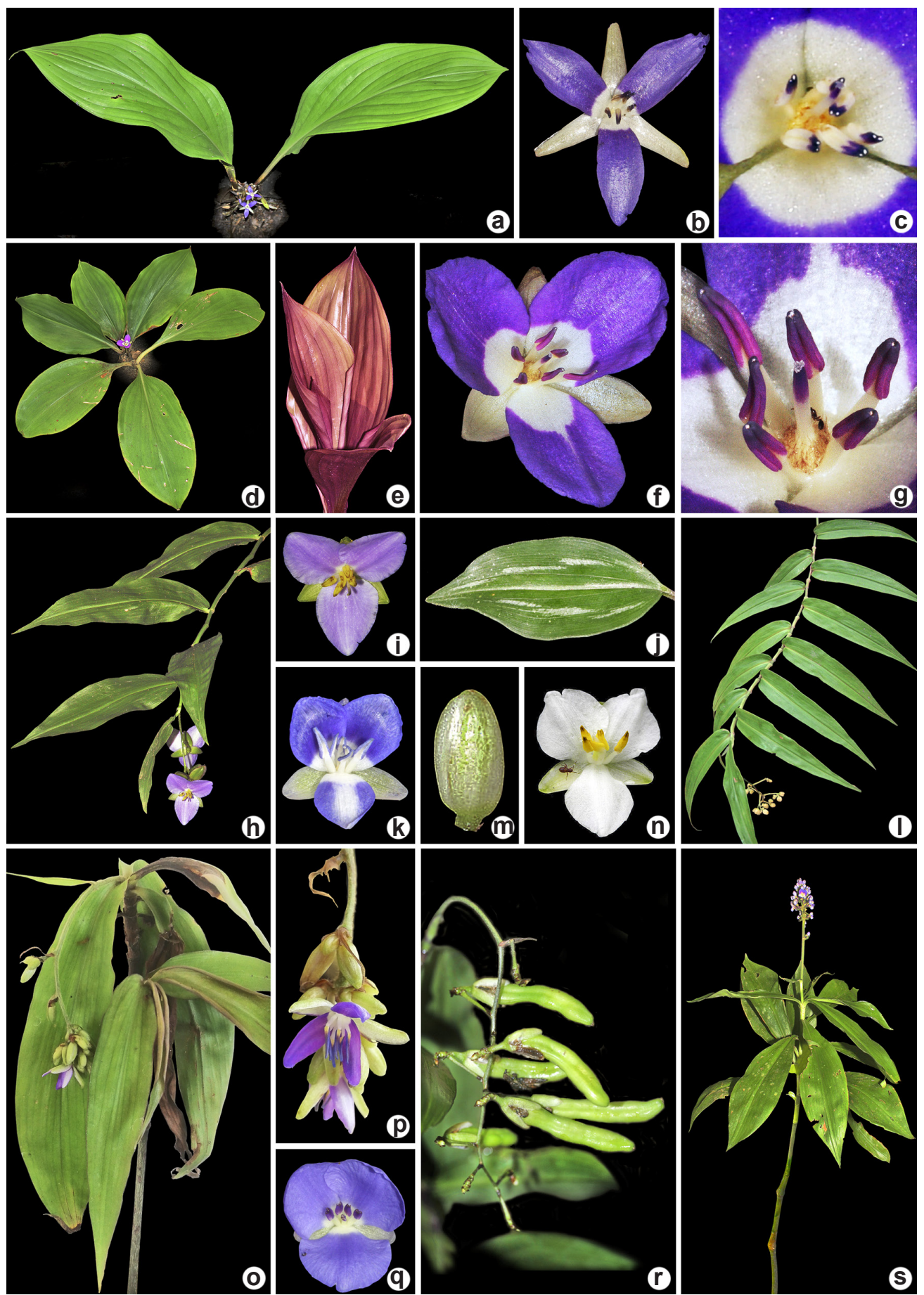

Figure 10 - a-s. Dichorisandra from the state of Espírito Santo, Brazil - a-c. D. acaulis - a. habit; b. front view of bisexual flower; c. androecium and gynoecium; d-g. D. forzzae - d. habit; e. detail of the pink to brownish-mauve young leaves; f. front view of bisexual flower; g. androecium and gynoecium; h-i. D. glabrescens - h. habit; i. front view of a bisexual flower. $\mathrm{j}-\mathrm{k}$. $D$. hexandra $-\mathrm{j}$. adaxial side of the leaf-blade; $\mathrm{k}$. front view of a bisexual flower; 1-n. D. incurva - 1. habit; m. floral buds; $\mathrm{n}$. front view of a bisexual flower; o-p. D. nutabilis - o. habit; p. detail of inflorescence; q-r. D. penduliflora - q. front view bisexual flower; r. detail of infructescence; s. D. paranaenses habit. (Photos: a-g, j-k, q, s. MOO Pellegrini; h-i. CN Fraga; 1. MS Wängler; m. L Menini Neto; n. GH Shimizu; o-p, r. QS Moraes). 
abaxially vinaceous to purple), large flowers ( $>2.2$ $\mathrm{cm}$ diam.), 5 stamens, anthers introrsely rimose (but functionally poricidal), white with upper half or third bluish-purple to purple, globose capsules, and 1-2 seeds per locule. The few seeded capsules are so far unique in Dichorisandra, with the remaining species of the genus presenting (3-)4-6 seeds per locule (Aona 2008). It is similar to D. variegata Aona \& M.C.E.Amaral and D. hirtella (Nees \& Mart.) Mart. ex Schult. f. due to its indumentum. It is further similar to D. variegata due to its silver-stripped leaves. It differs of both species by its hirsute to densely hirsute ovary (vs. glabrous), and globose capsules (vs. ellipsoid). It differs from $D$. variegata due to its spirally-alternatealternate leaves (vs. distichously-alternate) and from and $D$. hirtella due to its leaf-blades with silver longitudinal stripes (vs. leaf-blades without longitudinal stripes). It is also morphologically similar to D. glandulosa due to its small size (up to $50 \mathrm{~cm}$ tall), its vegetative organs, inflorescences, sepals, ovary and capsules densely hirsute with hyaline to light brown trichomes, large flowers, 5 stamens, and anthers introrsely rimose (but functionally poricidal) white with upper half or third bluish-purple to purple. However, it can be differentiated by its eglandular hirsute sepals, ovary and capsules ( $v s$. glandular-pubescent in $D$. glandulosa), leaves discolorous, adaxially dark green with silver longitudinal stripes and abaxially vinaceous to purple (vs. concolorous, green on both sides), capsules globose ( $v s$. cylindric), 1-2 seeds per locule ( $v s .3-6)$, testa light brown to reddishbrown (vs. dark brow).

4.3. Dichorisandra forzzae M.Pell. \& Q.Moraes, Nordic J. Bot. 38: 8. $2020 . \quad$ Figs. 9; 10d-g Herbs ca. $20-30 \mathrm{~cm}$ tall, terrestrial. Stems erect, unbranched, sericeous, trichomes hyaline. Leaves spirally-alternate; sheaths $2-5.5 \mathrm{~cm}$ long, setose, trichomes hyaline; pseudopetiole 0.9-3.8 cm long, sericeous, trichomes hyaline; blades $13-25.5 \times 6.5-11 \mathrm{~cm}$, ovate to obovate, chartaceous mature leaves, adaxially glabrous, green, abaxially sericeous, pink to brownish-mauve young leaves, base symmetric, cuneate to round, apex acute to acuminate. Inflorescence terminal, erect, not perforating the leaf-sheath; cincinni 4-9, with 2-3-flowered, main axis inconspicuous, sessile, cincinnus bract $0.5-1.8 \times 0.2-0.7 \mathrm{~cm}$, deltoid, medium brown, adaxially glabrous, abaxially sericeous; bracteoles $0.5-1 \mathrm{~cm}$ long, elliptic to lanceolate, sparsely sericeous. Flowers actinomorphic; pedicels $0.8-2 \mathrm{~cm}$ long, setose; sepals $1.3-1.7 \times 0.5-0.8 \mathrm{~cm}$, obovate, green, apex lilac to purple, sparsely sericeous; petals $1.2-1.5$ $\times 0.9-1.3 \mathrm{~cm}$, ovate to obovate, purple, basal third white; stamens 6 , homomorphic, filaments $2-5$ $\mathrm{mm}$ long, basally connate, anthers 5-7 mm long, poricidal, purple throughout or cream with purple apex, dehiscent through one apical pore; ovary 2-3 $\mathrm{mm}$, setose, style $6-8 \mathrm{~mm}$ long, slightly recurved at apex, white, stigma slightly trilobate. Capsules 3.3$4.5 \times 0.9-1.1 \mathrm{~cm}$, cylindric, green when immature, brown when mature, smooth, sparsely setose. Seeds 3-4.5 × 2-2.8 mm, dark brown to black, testa scrobiculate, hilum C-shaped, embryotega semilateral, aril slightly hyaline, colorless, spongy. Specimens examined: Fundão, Goiapaba-Açu, 9.II.2003, fl., A.P. Fontana 494 (MBML). Santa Teresa, 19.II.2005, fl., L.Y.S. Aona \& A.S.B. Gil 933 (UEC); road to Alto Santo Antônio, Vale do Canaã, 23.IV.1983, fl. and fr., A.L. Peixoto et al. 1803 (RB, UEC); road Santa Teresa/Nova Lombardia, Sítio do Sr. Alcebiades, 4.II.1985, fl., A.L. Peixoto et al. 3425 (MO, RB 2ex, US 2ex); Estação Biológica Santa Lúcia (EBSL), 23.II.1994, fl., C.C. Chamas et al. (MBML no. 45112); trilha do Túmulo, 26.I.2006, fl., L. Kollmann 8621 (MBML); 21.XI.2015, fl., M.O.O. Pellegrini 465 (RB, VIES); 13.XII.2016, fl., Q.S. Moraes 285 (VIES); 22.XII.2017, fl., Q.S. Moraes 303 (RB); 12.V.2018, fr., R.G. BarbosaSilva 1041 (HUEFS); Mata Fria, property of Clerio Loss, 27.I.1999, fl., L. Kollmann et al. 1703 (MBML); Nova Lombardia, Reserva Biológica Augusto Ruschi, 29.I.2002, fl., L. Kollmann 5363 (MBML); 19.II.2002, fl., L. Kollmann 5571 (MBML); 19.XII.2002, fl., R.R. Vervloet 1589 (MBML); 12.II.2003, fl., R.R. Vervloet et al. 1808 (MBML); propriedade de João Furlane, 18.XI.2005, fl., A.P. Fontana 1778 (MBML); São João de Petrópolis, Instituto Federal do Espírito Santo, 21.I.2011, fl., J.R. Pirani, 6128 (MBML, RB); Valão de São Brás, área da E.A.F.S.T., 16.I.2007, fl., R.C. Britto 154 (MBML). Santo Antônio, property of Boza, 14.I.1999, fl., L. Kollmann \& E. Bausen 1579 (MBML); São Lourenço, Estação Biológica da Caixa D'Água, 4.II.1986, fl., H.Q. Boudet Fernandes 1839 (MBML, US); 5.III.1999, fl. and fr., L. Kollmann 2034 (MBML); 29.III.2003, fl., A.P. Fontana 559 (MBML).

Dichorisandra forzzae is endemic to the state of Espírito Santo (Fig. 9). The largest known population is registered for the Estação Biológica Santa Lúcia (Moraes et al. 2020). Dichorisandra forzzae is morphologically most similar to the $D$. acaulis group (Moraes et al. 2020), an informal group named by Pellegrini \& Almeida (2016) composed of D. acaulis Cogn., D. nutabilis Aona \& M.C.E.Amaral, D. odorata Aona \& M.C.E.Amaral, D. picta Lodd. and D. perforans C.B.Clarke., but differs from it due to its pink to brownish-mauve 

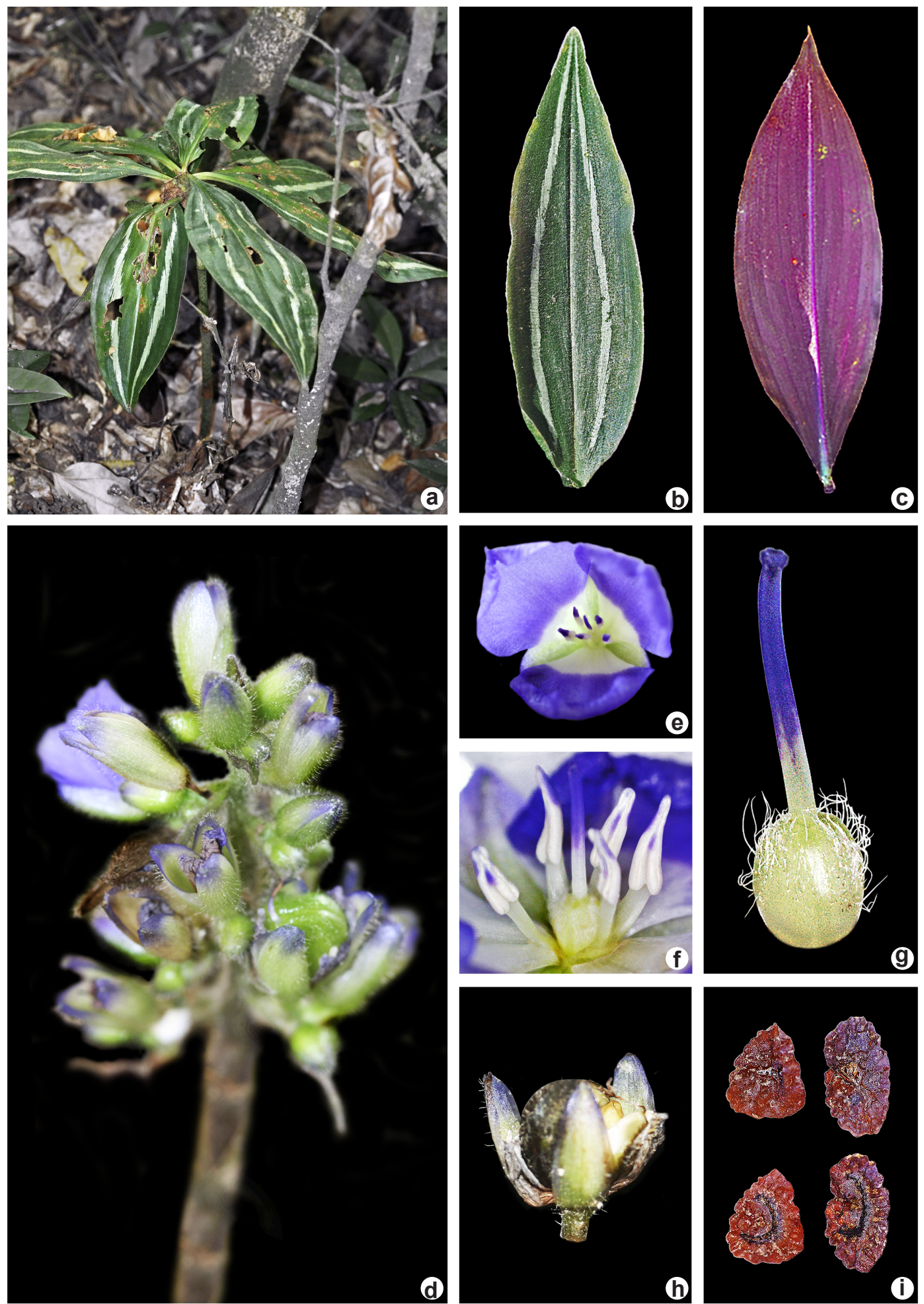

9
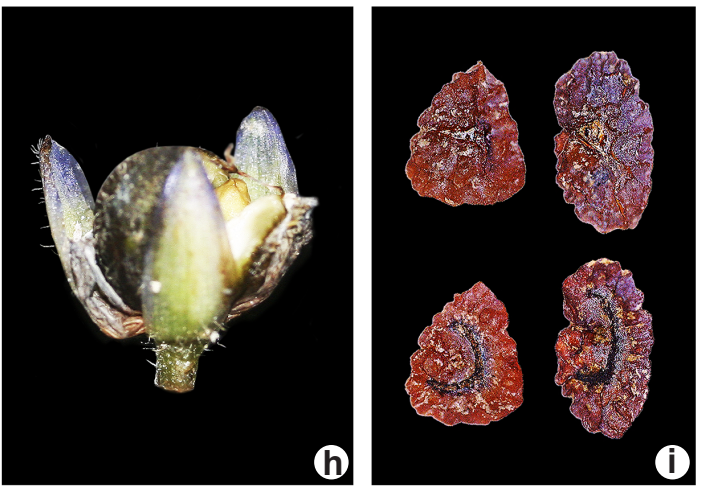

Figure 11 - a-j. Dichorisandra aonae sp. nov. - a. habit; b. adaxial side of the leaf-blade showing the longitudinal silver stripes; c. abaxial side of the leaf-blade showing the vinaceous to purple color; d. detail of inflorescence; e. front view of a bisexual flower; f. androecium; g. gynoecium; h. capsule; i. seed showing the details of C-shaped hilum and semilateral embryotega. (Photos: QS Moraes). 
young leaves (vs. light green), chartaceous mature leaves (vs. membranous), shorter pedicels $(\leq 2 \mathrm{~cm}$ $v s . \leq 4 \mathrm{~cm}$ long), sepals sparsely sericeous ( $v s$. glabrous, rarely sparsely setose at base), filaments basally connate ( $v s$. free), anthers dehiscence through one apical pore ( $v s$. two), and slightly trilobate white stigma ( $v s$. truncate, purple to mauve) (Moraes et al. 2020). It was collected with flowers from November to March and fruits in March and April (Moraes et al. 2020).

4.4. Dichorisandra glabrescens (Seub.) Aona \& M.C.E.Amaral, Brittonia 69(2): 215. 2016.

Figs. 10h-i; 13

Vining herbs $0.8-1.7 \mathrm{~m}$ tall, terrestrial. Stems vining, branched, glabrescent to sparsely hispid, trichomes hyaline. Leaves distichouslyalternate; sheaths $1.5-3 \mathrm{~cm}$ long, glabrescent to sparsely hispid, margins setose, trichomes hyaline; pseudopetiole 1-2 mm long, glabrous; blades 6-15 $\times 1.5-4 \mathrm{~cm}$, elliptic to lanceolate, concolorous, green, glabrescent on both sides, base asymmetric, cuneate, apex acuminate. Inflorescence terminal, pendulous, not perforating the leaf-sheath; peduncle 1-1.5 cm long, sparsely shortly-pilose; cincinni 9-16, 3-7-flowered; cincinnus bracts $0.8-2 \times 0.1-0.2 \mathrm{~cm}$, lanceolate, green, glabrescent; bracteoles 2-3 mm long, deltoid, brown, sparsely hispid. Flowers actinomorphic; pedicels 1.5-2.2 $\mathrm{mm}$ long, glabrescent; sepals 5.5-8 × 4-6 mm, ovate, green, glabrescent; petals 7-9 × 3-5 mm, obovate, evenly colored, pale blue to lilac; stamens 5-6, subequal, all pointing up; filaments 2-3 $\mathrm{mm}$ long, anthers 4-5 × 0.8-1.3 $\mathrm{mm}$, introrsely rimose (but functionally poricidal), yellow; ovary 1-2 × 0.8-1.9 mm, glabrous, style 4-6 mm long, recurved, white, stigma capitate. Capsules 1-1.2 $\times$ 0.4-0.6 cm, ellipsoid, smooth, straight, green when immature, brown when mature, smooth, glabrous. Seeds not seen.

Specimens examined: Governador Lindenberg, propr. Fernando Nicolli, 5.XI.2007, fl., V. Demuner et al. 4452 (MBML). Nova Venécia, Área de Proteção Ambiental da Pedra do Elefante, Serra de Baixo, 14.IV.2009, R.C. Forzza et al. 5514 (MBML, RB). São Mateus, ligação rodovia BR-101, 14.X.1992, fl. and fr., G. Hatschbach et al. 58046 (MBM, MO, US). São Roque do Canaã, Alto Santa Júli, Jacutinga, 14.I.2008, fl., M.M. Saavedra $633(\mathrm{RB})$.

Dichorisandra glabrescens is endemic to Brazil, found in the states of Pernambuco, Bahia, Espírito Santo (Fig. 13), and Minas Gerais, in the Caatinga and Atlantic Forest domains (Aona et al. 2020). Morphologically similar to D. incurva (view comments for $D$. incurva). However, $D$. glabrescens has consistently vining stems (vs. scrambling or ascending with decumbent at apex), actinomorphic corolla (vs. zygomorphic), and petals pale blue to lilac ( $v s$. white). This species has been rarely collected in fruits, and seeds are still unknown for it. Thus, our description was complemented with data from Aona et al. (2016b). The species has not had its conservation assessed yet. The information available in the herbaria indicate it flowers from October to April. Immature fruits were collected in October.

4.5. Dichorisandra glandulosa Q.Moraes \& M.Pell., sp. nov. Type: BRAZIL. ESPÍRITO SANTO: Águia Branca, Assentamento 16 de abril, 5.II.2018, fl. and fr., Q.S. Moraes 293 (holotype: VIES).

Figs. 12a-g; 13; 14

Dichorisandra glandulosa sp. nov. is characterized by its small stature (up to $40 \mathrm{~cm}$ tall), hirsute to densely hirsute stems and leaves, glandular-pubescent inflorescences, pedicels, sepals, ovary and capsules, five stamens, anthers introrsely rimose but functionally poricidal, white with upper half or third bluish-purple to purple, ellipsoid capsules, and 3-6 seeds per locule.

Herbs 20-40 cm tall, terrestrial. Roots fibrous with terminal fusiform to broadly ellipsoid tubers. Stems erect, branched, internodes $0.5-8.4 \mathrm{~cm}$ long, dark green to greenish-brown to brownishvinaceous, hirsute, trichomes hyaline. Leaves spirally-alternate, congested at the apex of the stem; sheaths 1-1.5 cm long, white to light green, hirsute to densely hirsute, margins hirsute, trichomes hyaline; pseudopetiole 5-10 mm long, canaliculate, hirsute, trichomes hyaline; blades $7-15.5 \times 2.5-5 \mathrm{~cm}$, elliptic to oblanceolate, slightly succulent, concolorous, adaxially green, abaxially light green, hirsute to densely hirsute in both sides, base symmetric, cuneate, margins hirsute, apex acuminate, trichomes hyaline; primary vein conspicuous adaxially, impressed, light green, prominent abaxially, obtuse; secondary veins 3-5 pairs, slightly conspicuous on both sides, becoming more evident upon drying. Inflorescence terminal, erect, not perforating the leaf-sheath; basal bract $0.5-1.6 \times 0.2-0.4 \mathrm{~cm}$, bracteose, linear-lanceolate to lanceolate, green, hirsute, trichomes hyaline to light brown; peduncle 4-10 $\mathrm{mm}$ long, green, glandular-pubescent, trichomes hyaline; main axis 5-8 cm long, green, glandular-pubescent, trichomes hyaline; cincinni 5-8, alternate, 3-5-flowered, peduncle 1.5-6.3 mm long, glandular-pubescent, 


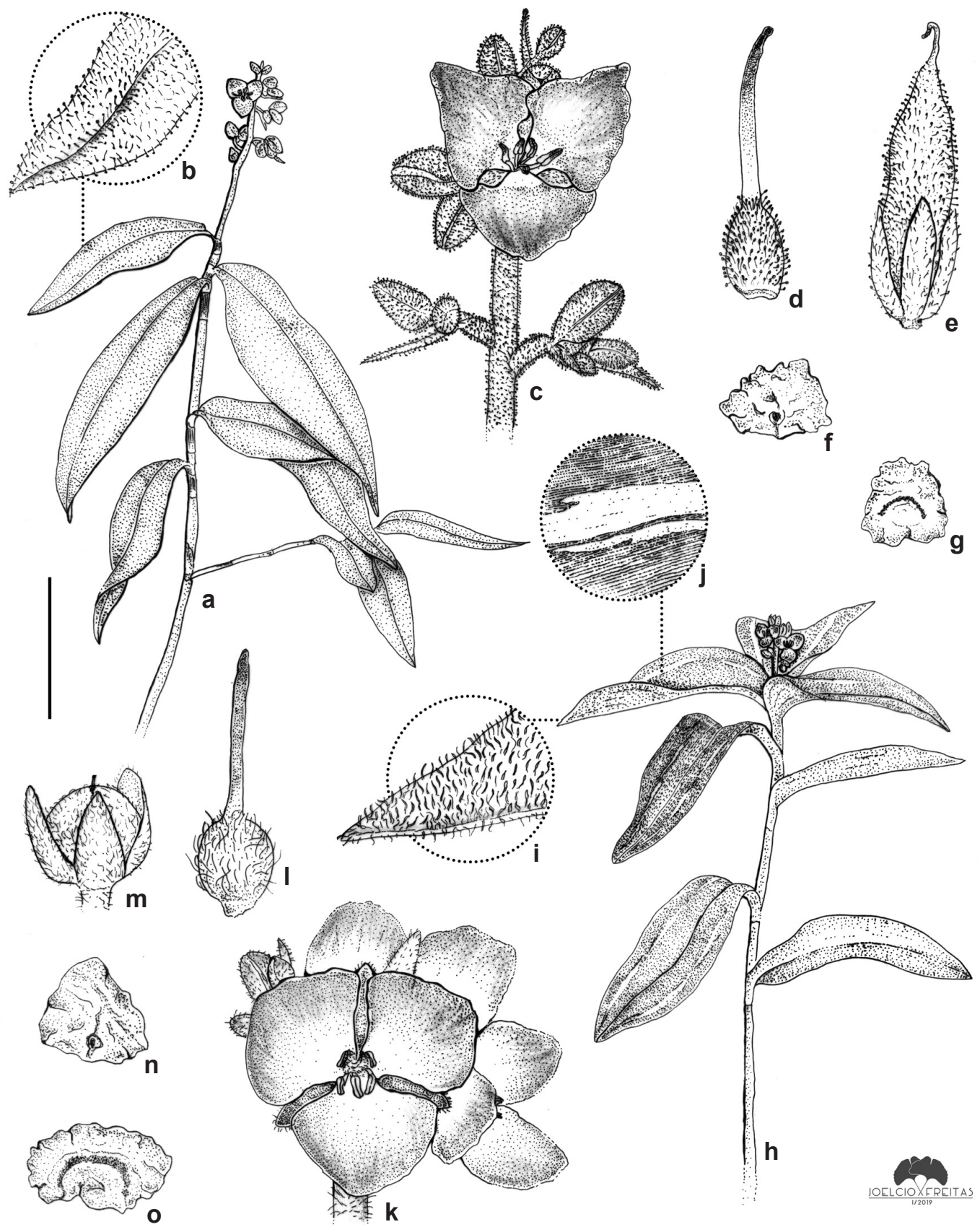

Figure 12 - a-g. Dichorisandra glandulosa sp. nov. - a. habit, showing spirally-arranged leaves and terminal inflorescence; b. detail of the leaf-blades with hirsute indumentum and trichomes glandular on both sides; c. inflorescence and front view of a bisexual flower; d. gynoecium; e. immature capsules; f-g. seed showing the scrobiculate ornamentation - f. detail of semilateral embryotega; g. details of C-shaped hilum; h-o. Dichorisandra aonae sp. nov. - h. habit, showing spirally arranged leaves, and terminal inflorescence; i-j. detail of the leaf-blades - i. hirsute indumentum and trichomes simple on both sides; j. silver longitudinal stripes on the upper leaf surface; k. inflorescence and front view of a bisexual flower; 1. gynoecium; m. immature capsules; n-o. seed showing the scrobiculate ornamentation $-\mathrm{n}$. detail of semilateral embryotega; o. details of C-shaped hilum. Scale bars: $\mathrm{a}=7 \mathrm{~cm}$; $\mathrm{b}=2,5 \mathrm{~cm} ; \mathrm{c}=1 \mathrm{~cm} ; \mathrm{d}=3 \mathrm{~mm} ; \mathrm{e}=1,2 \mathrm{~cm} ; \mathrm{f}, \mathrm{g}=4,5 \mathrm{~mm} ; \mathrm{h}=10 \mathrm{~cm} ; \mathrm{i}=1 \mathrm{~cm} ; \mathrm{j}=1,5 \mathrm{~cm} ; \mathrm{k}=1,8 \mathrm{~cm} ; 1=3,5 \mathrm{~mm}$; $1=1,3 \mathrm{~cm} ; \mathrm{n}, \mathrm{o}=6,5 \mathrm{~mm}$. (a-g. Moraes 293; h-o. Moraes 239). Line drawings by J Freitas. 
trichomes hyaline; cincinnus bracts $0.3-1.8 \times 0.1-$ $0.2 \mathrm{~cm}$, lanceolate, green, hirsute, with a mixture of glandular and eglandular trichomes, hyaline, apex acuminate; bracteoles $1.5-4 \mathrm{~mm}$ long, deltoid, green, hirsute, trichomes hyaline. Flowers bisexual or staminate, zygomorphic, 1.6-2 cm diam; pedicels 1-2 mm long, green, glandular-pubescent, trichomes hyaline; floral buds $0.5-0.9 \times 0.2-0.6$ $\mathrm{cm}$, green, apex purple, ovoid; sepals $0.8-1 \times 0.3-$ $0.5 \mathrm{~cm}$, ovate, membranous, green, apex purple, glandular-pubescent, trichomes hyaline, margins glabrous; petals $1-1.1 \times 1.1-1.2 \mathrm{~cm}$, rhomboid to very widely obovate, bluish-purple to purple, basal third white; stamens 5, subequal, all pointing up; filaments $1.5-3 \mathrm{~mm}$ long, curved upwards, white, slightly twisted, anthers 3-4 mm long, rimose (but functionality poricidal), white, upper half or third purple, slightly falcate, base sagittate, apex acute; upper medial staminode absent; ovary $1.3-2 \times$ 0.8-1.4 mm, ovoid, glandular-pubescent, trichomes hyaline, style 2.5-3.5 mm long, curved, base white, purple at apex, stigma truncate, bluish-purple. Capsules 1.9-2.4 × 0.5-0.6 cm, ellipsoid, green when immature, brown when mature, smooth, glandular-pubescent, trichomes hyaline. Seeds 3-6 per locule, $2-3 \times 1.5-2 \mathrm{~mm}$, narrowly ellipsoid to ellipsoid; testa scrobiculate, dark brown; hilum C-shaped; embryotega semidorsal; aril opaque, white, thick, spongy.

Specimens examined (paratypes): Águia Branca, assentamento 16 de abril, 13.XII.2017, fl., Q.S. Moraes 230 (VIES); 13.XII.2017, fl., Q.S. Moraes 288 (RB); 5.II.2018, fr., Q.S. Moraes 292 (RB).

The epithet "glandulosa" makes reference to this species glandular-pubescent inflorescences, sepals, ovary and capsules, which are unique in the genus.

Dichorisandra glandulosa is endemic to Águia Branca (Espírito Santo), growing in rainforest remnants (Fig. 13). This species presents a small stature (up to $40 \mathrm{~cm}$ tall), hirsute to densely hirsute stems and leaves, glandular-pubescent inflorescences, pedicels, sepals, ovary and capsules (which are unique in the genus), large flowers (up to $2 \mathrm{~cm}$ diam), 5 stamens, anthers introrsely rimose (but functionally poricidal), white with upper half or third bluish-purple to purple, ellipsoid capsules, and 3-6 seeds per locule. It resembles D. pubescens Mart. ex Schult. f. in its small erect habit (40-50 $\mathrm{cm}$ tall) and green and densely pilose leaves. However, D. glandulosa has 5 stamens (vs. six in D. pubescens), introrsely rimose and functionally poricidal anthers (vs. poricidal), and glandular- pubescent ovary and capsules ( $v s$. glabrous). It is also similar to D. puberula Nees \& Martius due to its 5 stamens, 5 stamens, anthers introrsely rimose (but functionally poricidal), white with upper half or third bluish-purple to purple, and capsules longer than wide. However, D. glandulosa has hirsute to densely hirsute leaves ( $v s$. adaxially glabrescent and abaxially glabrous), and ovary and capsules glandular-pubescent (vs. glabrous). Dichorisandra glandulosa is most similar to D. aonae (see comments above). However, it can be differed by its concolorous leaves (vs. discolorous, adaxially dark green with longitudinal silver stripes, abaxially vinaceous to purple in D. aonae), and glandularpubescent inflorescences, pedicels, sepals, ovary and capsules ( $v s$. hirsute).

4.6. Dichorisandra hexandra (Aubl.) C.B.Clarke., Bull. Torrey Bot. Club 29(2): 703. 1902.

Figs. 10j-k; 13

Vining herbs $0.5-2 \mathrm{~m}$ tall, terrestrial or rupicolous. Stems ascending, scrambling or vining, branched, glabrous to sparsely pilose, trichomes hyaline. Leaves distichously-alternate; sheaths 1-2 $\mathrm{cm}$ long, glabrescent, margins lanate, trichomes hyaline; pseudopetiole 1-2 mm long, pubescent, trichomes hyaline; blades 5-10.8 × 1.5-2.6 cm, elliptic to lanceolate to oblanceolate, to obovate, discolorous, abaxially green, glabrous to sparsely pilose, when present congested at the base or along the midvein, adaxially green sometimes with longitudinal silver stripes, glabrous, base

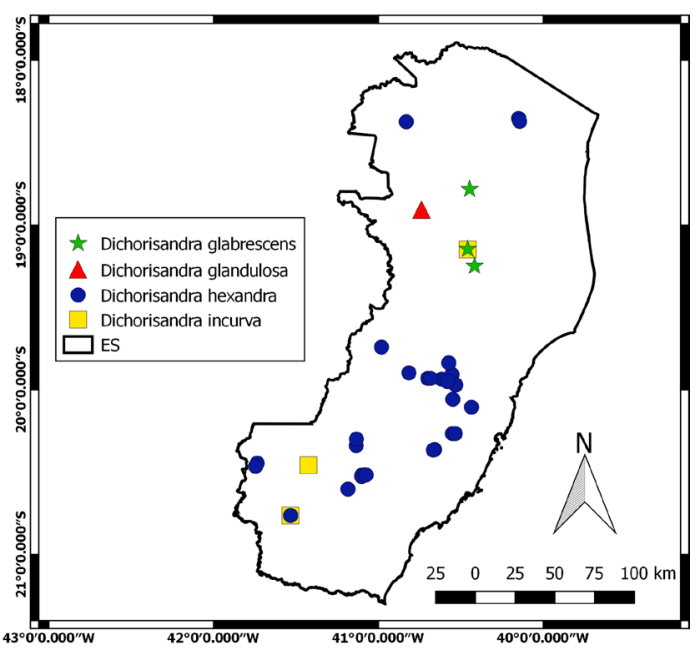

Figure 13 - Geographic distribution of Dichorisandra glabrescens, D. glandulosa, D. hexandra, D. incurva in the state of Espírito Santo. 
symmetric, cuneate, apex acuminate. Inflorescence terminal, erect, rarely ascending or patent, not perforating the leaf-sheath; peduncle 5-15 $\mathrm{mm}$ long; cincinni 9-14, 3-5-flowered; cincinnus bract 2-3.5 × 1-2 mm, lanceolate, green, glabrescent; bracteoles 1-1.3 mm long, deltoid, sparsely pubescent. Flowers zygomorphic; pedicels 2-3 $\mathrm{mm}$ long, pubescent; sepals 6-8 × 3-4 mm, ovate, green, glabrous to sparsely pilose along the midvein; petals 7-9 × 3-5 mm, obovate, bluishpurple to purple, basal third white; stamens 6 , subequal, all pointing up; filaments $2-3 \mathrm{~mm}$ long, anthers 4-5 × 1-1.2 mm, poricidal, dehiscent by two apical pores, white to cream, upper half bluish-purple to purple; ovary $1.8-2.5 \times 2-2.6$ $\mathrm{mm}$, glabrous, style 5-6 mm long, recurved, stigma capitate. Capsules 5-8 × 5.8-8.5 mm, globose, smooth with a verrucose apex, glabrous, green, apex vinaceous to atro-vinaceous. Seeds 3.8-5.6 $\times 2.5-3 \mathrm{~mm}$, testa scrobiculate, dark brown, hilum C-shaped, embryotega semidorsal, aril opaque, orange, thick, spongy.

Specimens examined: Cariacica, Pau Amarelo, 6.V.2008, fr., A.P. Fontana 5192 (MBML, RB). Castelo, 9.IV.2009, fl., L. Kollmann 11517 (MBML, RB); Parque Estadual Forno Grande, Bateias, 13.II.2008, fl., R.C. Forzza 4995 (MBML, RB); 26.III.2005, fr., L. Kollmann et al. 7604 (MBML). Ibitirama, Santa Marta, 23.III.2012, fl. and fr., J. Kuntz et al. 644 (VIES). Itarana, Alto Limoeiro de Santo Antonio, propriedade de Vitor Possmoser, 11.II.2013, fl., V.B. Sarnaglia Jr 654 (RB). Linhares, estrada para o Barro Novo, 13.V.1977, fl., G. Martinelli 2041 (RB). Pinheiros, Reserva Biológica Córrego do Veado, 30.V.2008, fl., L. Kollmann \& L. Magnago 11043 (MBML). Santa Teresa, Reserva Biológica Augusto Ruschi, Nova Lombardia, 5.II.1985, fl., A. Peixoto 3514 (RB).

Dichorisandra hexandra have a wide distribution, ranging from Mexico to Argentina (Barreto 1997; Aona 2008). It is broadly distributed in Brasil, being found in all Brazilian states (Aona et al. 2020). In Espírito Santo, it can be generally found growing understory in semideciduous seasonal forest and rainforests (Fig. 13). The species is characterized by its vining or scrambling habit, leaves varying in shape (elliptic to lanceolate to oblanceolate, to obovate), size (5-10.8 $\times$ $1.5-2.6 \mathrm{~cm}$ ) and pubescence, 6 stamens, poricidal, dehiscent by two apical pores, white to cream, upper half bluish-purple to purple, globose capsules with sparsely verrucose and atro-vinaceous apex, and orange aril. Dichorisandra hexandra has not had its conservation assessed yet. Flowers and fruits were recorded throughout the year.
4.7. Dichorisandra incurva Mart. ex Schult. f., Syst. Veg. (ed. 15 bis) 7(2): 1184. Figs. 101-n; 13 Vining or erect herbs $50-80 \mathrm{~cm}$ tall., terrestrial. Stems scrambling or ascending with decumbent apex, branched, sparsely hispid, trichomes hyaline. Leaves distichously-alternate; sheaths 1.5-2 cm long, hispid, margins setose, trichomes hyaline; pseudopetiole 1-3 $\mathrm{mm}$ long, hispidulous, trichomes hyaline; blades 8-12 $\times$ $1.3-2.5 \mathrm{~cm}$, elliptic to lanceolate, concolorous, green, glabrous on both sides, base asymmetric, cuneate, apex acute to acuminate. Inflorescence terminal, pendulous, not perforating the leafsheath; peduncle $0.8-1.3 \mathrm{~cm}$ long; sparsely shortlypilose; cincinni 6-8, 1-3-flowered; cincinnus bract $0.5-1 \times 0.2-0.4 \mathrm{~cm}$, deltoid, brown, hispid; bracteoles 1-2 mm long, deltoid, brown, sparsely hispid. Flowers zygomorphic; pedicels $1.5-3 \mathrm{~mm}$ long, hispid; sepals 7-9 × 3-4 mm, ovate, green, glabrescent; petals 9-12 × 3-5 mm, obovate, evenly colored, white; stamens 6 , subequal, all pointing up; filaments 2-4 mm long, anthers 3-4 × 0.8-1.3 $\mathrm{mm}$, introrsely rimose (but functionally poricidal), yellow; ovary $1-1.5 \times 0.5-1 \mathrm{~mm}$, glabrous, style 2.5-4 mm long, linear, white, stigma capitate. Capsules $1.3-2 \times 0.4-0.6 \mathrm{~cm}$, ellipsoid, smooth, straight, green when immature, brown when mature, smooth, glabrous. Seeds ca. $2 \times 2 \mathrm{~mm}$, dark brown, testa scrobiculate, hilum C-shaped, embryotega semidorsal, aril opaque, white, spongy. Specimens examined: Alegre, Parque Nacional do Caparaó, arredores do Rio Norte, 22.II.2000, fl., V.C. Souza et al. 23644 (ESA, UEC). Governador Lindeberg, Morelo, propriedade Fernando Nicolli, 13.XI.2006, fl., $V$. Demuner 3024 (MBML). Muniz Freire, afloramento na rodovia sentido Iúna, mantido sob cultivo, 4.V.2018, fl., Q.S. Moraes et al. 296(VIES); 4.V.2018, fl., Q.S. Moraes et al. 298 (VIES). Santa Maria do Jetibá, Rio Nove, 23.VIII.2004, fl., L. Kollmann et al. 7030 (MBML).

Dichorisandra incurva is endemic to Brazil, being recorded for Bahia, Espírito Santo, Rio de Janeiro, Minas Gerais, São Paulo, and Paraná (Aona et al. 2020). In Espírito Santo (Fig. 13), it occurs in semideciduous seasonal forests and shaded areas of rocky outcrops. It is morphologically similar to $D$. glabrescens due to its asymmetric leaf base, floral morphology, 6 stamens, and anthers introrsely rimose (but functionally poricidal) and yellow. However, it differs by its stems scrambling or ascending with decumbent apex (vs. vining in D. glabrescens), and white petals (vs. light blue to lilac). Dichorisandra incurva has not had its conservation assessed yet. Flowers were recorded from August to May. 

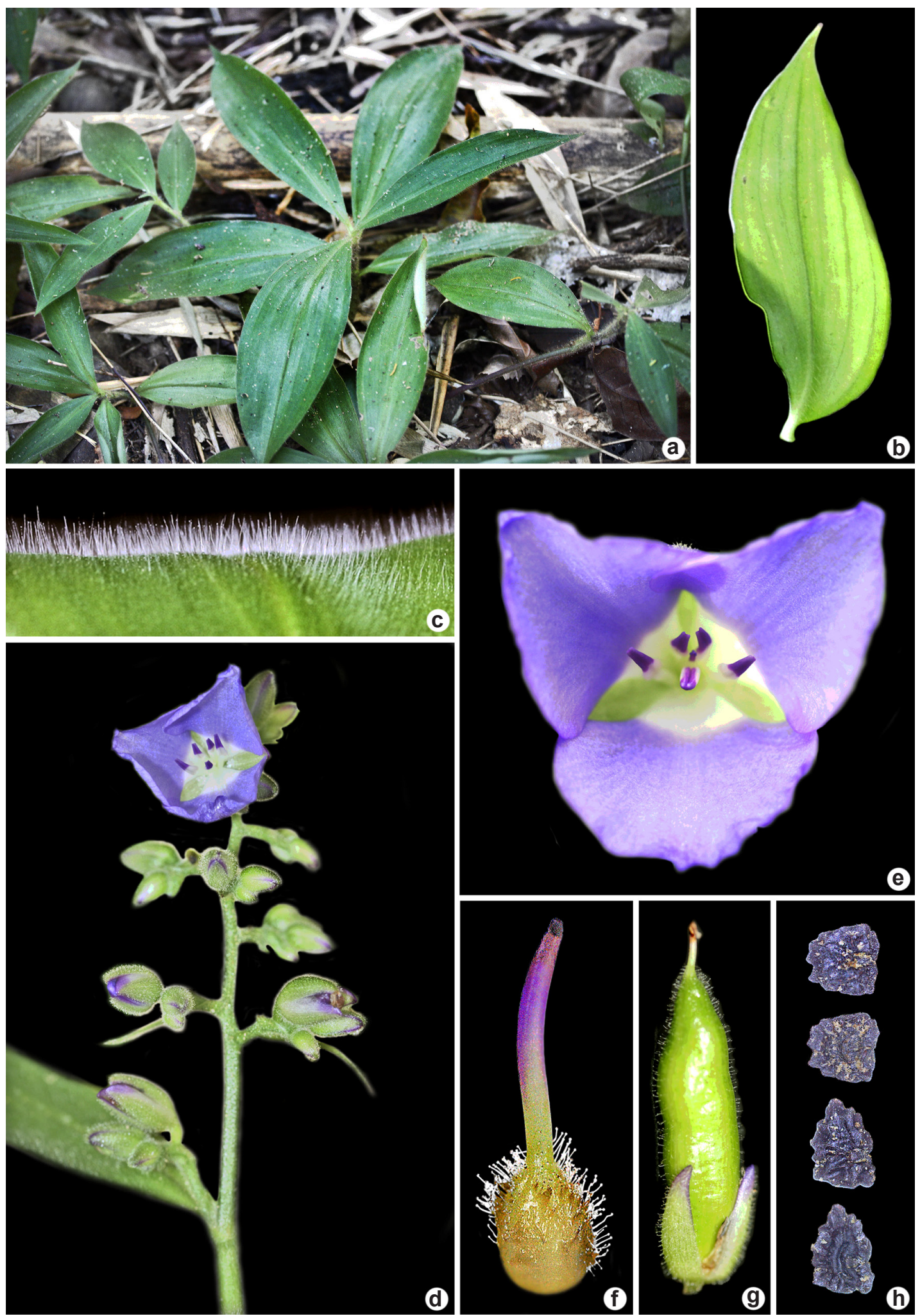

Figure 14 -a-h. Dichorisandra gladulosa sp. nov. - a. habit; b. adaxial side of the leaf-blade showing the green to light green color; c. detail of the indumentum; d. detail of inflorescence; e. front view of a bisexual flower; f. gynoecium; g. capsule; h. seed showing the details of C-shaped hilum and semilateral embryotega. (Photos: QS Moraes). 
4.8. Dichorisandra neglecta Brade, Arch. Jard. Bot. Rio de Janeiro 15: 8. 1957.

Herbs 30-60 cm tall, terrestrial. Stems erect, unbranched, glabrous. Leaves spirally-alternate; sheaths $4-6 \mathrm{~cm}$ long, glabrescent, margins hirsute, trichomes rusty-brown; pseudopetiole $2-3.2 \mathrm{~mm}$ long, glabrous; blades $15-20 \times 3.7-5 \mathrm{~cm}$, elliptic to lanceolate, concolorous, green, glabrous on both sides, base symmetric, cuneate, apex acuminate. Inflorescences lateral, perforating the leaf-sheaths, erect; peduncle 1-1.2 cm long, hirsute, trichomes rusty-brown; cincinni 2-4, 2-5-flowered; cincinnus bracts $2-3 \times 0.2-0.3 \mathrm{~cm}$, lanceolate, hirsute, trichomes rusty-brown; bracteoles $1-1.5 \mathrm{~mm}$ long, hirsute, trichomes rusty-brown. Flowers zygomorphic; pedicels ca. $5 \mathrm{~mm}$ long, sparsely hirsute, trichomes rusty-brown; sepals ca. $7 \times 4-5$ $\mathrm{mm}$, white, apex purple, hirsute, trichomes rustybrown; petals ca. $9 \times 5 \mathrm{~mm}$, ovate, white; stamens 5-6, dimorphic (the posterior with large and connivent anthers, the anterior with small and free anthers), filaments $1-2 \mathrm{~mm}$ long, anthers $4-5 \mathrm{~mm}$ long, introrsely rimose (but functionally poricidal), yellow; ovary ca. $2 \times 2 \mathrm{~mm}$, glabrous, style 3.5-4 $\mathrm{mm}$ long, straight, stigma truncate. Capsules not seen. Seeds not seen.

Specimens examined: Cachoeiro de Itapemirim, Fazenda Santo Antônio da Pedra Branca, V.1949, fl., A.C. Brade 20561 (HB, RB).

Dichorisandra neglecta is only known from the type material, collected in Cachoeiro de Itapemirim, southern Espírito Santo (Brade 1957). The morphologic variation of $D$. neglecta is still poorly understood, and fruit and seed characters are still unknown. In the present study, intensive fieldwork was done in the region. However, we were unable to recollect this species. Dichorisandra neglecta is currently categorized as Critically Endangered (CR) (CNCflora 2012b), but following the IUCN (2012) recommendations, it should be considered Extinct (EX) since it has been over 50 years since it was last collected. The information provided by Brade (1957) indicates it flowers in January. It is morphologically similar to Dichorisandra sp. due to its inflorescences perforating the leaf-sheaths, enclosed by peduncle bracts, petals white, and unique dimorphic stamens (the posterior with large and connivent anthers, the anterior with small and free anthers).

4.9. Dichorisandra nutabilis Aona \& M.C.E. Amaral, Phytotaxa 48: 18: 2012. Figs. 10o-p; 15

Herbs $20-70 \mathrm{~cm}$ tall, terrestrial. Stems erect, unbranched, rarely branched, glabrous or setose, trichomes hyaline. Leaves spirally-alternate; sheaths $1-3 \mathrm{~cm}$ long, sparsely setose, margins setose, trichomes hyaline; pseudopetiole $0.3-3 \mathrm{~cm}$ long, setose, trichomes hyaline; blades 9-19.7 $\times$ 2-7.7 cm, elliptic to ovate to obovate, concolorous, green, sparsely velutine on both sides, trichomes hyaline, base symmetric, cuneate to round, apex acuminate to long-acuminate. Inflorescence terminal, pendulous, not perforating the leafsheath; developed main axis; peduncle $1-4 \mathrm{~cm}$ long; cincinni 2-15, 3-6-flowered; cincinnus bract $5-15 \times 1-3 \mathrm{~mm}$, deltoid, green, abaxially pilose; bracteoles $2-5 \mathrm{~mm}$ long, deltoid, brown, abaxially pilose. Flowers actinomorphic; pedicels $1-35 \mathrm{~mm}$ long, glabrous to sparsely pilose; sepals $0.8-1.4$ $\times 0.3-0.6 \mathrm{~cm}$, elliptic, green, glabrous to sparsely pilose; petals $0.8-1.5 \times 0.5-0.9 \mathrm{~cm}$, ovate to elliptic to oblanceolate, mauve to pinkish-purple to purple, basal third white; stamens 6, homomorphic, filaments $2-3.5 \mathrm{~mm}$ long, anthers 3-6 mm long, poricidal, dehiscent by one pore apical, white, upper half or third mauve to purple; ovary 2-3 $\times 1-2.5$ $\mathrm{mm}$, pilose, style 4-9 $\mathrm{mm}$ long, straight, white at base, mauve to purple, stigma slightly trilobate. Capsules 1.9-2.5 × 0.4-0.6 cm, cylindric, green when immature, brown when mature, smooth, sparsely pilose. Seeds $4.6-7.8 \times 2-3.2 \mathrm{~mm}$, black, rugose, hilum $\mathrm{C}$-shaped, embryotega semilateral, aril hyaline, colorless, thin.

Specimens examined: Cachoeiro do Itapemirim, Barra Alegre, 3.I.2009, fl., A.H. Krahl \& G.R. Souza 164 (VIES). Castelo, Parque Estadual de Mata das Flores, 19.I.2013, fl., T.T. Carrijo et al. 1599 (VIES); 25.II.2013, fl., T.T. Carrijo et al. 1674 (VIES); 10.XII.2013, fl., T.T. Carrijo et al. 1917 (VIES). Linhares, 26.III.2008, fl., D.A. Folli 5997 (CVRD, HURB, RB); 8.II.2007, fl., J.R. Stehmann 4725 (CVRD, RB); perto do Ninho do Gavião, 13.IV.2012, fl., G.S. Siqueira 733 (CVRD); 3.III.2020, fl., G.S. Siqueira 1343 (CVRD). Nova Venécia, APA Pedra do Elefante, 19.II.2008, fl., R.C. Forzza 5114 (MBML, RB); 13.XII.2017, fl., Q.S. Moraes 286(VIES); Fazenda Santa Rita, ao pé da pedra da torre, 16.II.2018, fl. J. Gurtler \& S.C. Dutra 436 (VIES); 7.V.2018, fl., Q.S. Moraes 302 (VIES). Santa Cruz, Aldeia Candeias Velha, 26.III.1997, fl. and fr., M.A. Assis 920 (HRCB). Santa Teresa, 30.I.2006, fl., L.Y.S. Aona 1491 (CVRD, G, UEC, US).

Dichorisandra nutabilis is endemic to Espírito Santo (Fig. 15), growing in the mountain region, understory in rainforests and semideciduous seasonal forests (Aona et al. 2020). It is recognized by its pendulous inflorescences with a developed main axis, actinomorphic flowers, 6 homomorphic stamens, and anthers dehiscent by one apical pore. According to Aona-Pinheiro \& Amaral (2012), the 
species is categorized as Endangered (EN). Flowers were recorded from December to May and fruits in March.

4.10. Dichorisandra paranaensis D.Maia et al., Fontqueria 55(40): 297. 2006 Figs. 10s; 15

Herbs $0.8-3 \mathrm{~m}$ tall, terrestrial. Stems erect, branched, glabrous. Leaves spirally-alternate; sheaths 1-1.5 cm long, glabrous; pseudopetiole 1-5 mm long, glabrous; blades 10-30×3-10 cm, elliptic to lanceolate, discolorous, adaxially dark green, stripes absent, abaxially light green or vinaceous to purple, glabrous on both sides, base symmetric, cuneate, apex acuminate. Inflorescence terminal, erect, not perforating the leaf-sheath; peduncle 0.5-3 cm long; cincinni 15-28, 3-8-flowered; cincinnus bracts $1-3.5 \times 0.3-1.5 \mathrm{~cm}$, lanceolate, vinaceous, glabrous; bracteoles $0.5-1 \mathrm{~cm}$ long, deltoid, vinaceous, glabrescent to puberulous. Flowers zygomorphic; pedicels 3-5 mm long, puberulous; sepals $0.5-1 \times 0.4-0.7 \mathrm{~cm}$, ovate, vinaceous, puberulous; petals $0.8-1.5 \times 0.5-1.3$ $\mathrm{cm}$, obovate, bluish-purple to purple, basal third white; stamens $5(-6)$, subequal, all pointing up; filaments $1.5-3.6 \mathrm{~mm}$ long, anthers $3-5 \times 0.9-1.2$ $\mathrm{mm}$ long, introrsely rimose (but functionally poricidal), yellow; medial staminode sometimes present; ovary 2-3 × 1.5-2 mm, glabrous; style $3.2-5 \mathrm{~mm}$ long, curved, white at base, upper half or third lilac to bluish-purple; stigma truncate. Capsules 1.2-2 × 1.2-2.3 cm, globose, vinaceous, glabrous. Seeds 4-8 × 2-5 mm; testa scrobiculate; hilum C-shaped; embryotega semidorsal; aril opaque, white, thick, spongy.

Specimens examined: Barra de São Francisco, Parque Municipal Sombra da Tarde, 21.XI.2000, fl., L. Kollmann et al. 3274 (MBML); 21.XI.2000, fl., L. Kollmann et al. 3351 (MBML). Iúna, Serra do Valentim, ambiente de grota, próximo ao transecto 5, 19.IV.2012, fl., J.P.F. Zorzanelli et al. 362 (VIES); 19.IV.2012, fl., J.P.F. Zorzanelli et al. 363 (VIES). Marilândia, rodovia Marilândia-Rio Bananal, ca. 1 km N de Marilândia, 6.XII.1994, fl., J.R.Pirani 3416 et al. (SPF, UEC). Nova Venécia, Área de Proteção Ambiental Pedra do Elefante, Serra de Baixo, Mata do Fuxico, 14.IV.2009, fl. and fr., C.N. Fraga et al. 2508 (CEPEC, MBML, RB); 8.XII.2017, fl. and fr., H.V. Pinto Junior et al. 366 (SAMES); 21.III.2018, fr., H.V. Pinto Junior et al. 388 (SAMES).

Dichorisandra paranaënsis is endemic to Brazil, being recorded for the states of Bahia, Espírito Santo (Fig. 15), Minas Gerais, Rio de Janeiro, São Paulo, Paraná, and Santa Catarina (Aona et al. 2020). It is characterized by its robust stature, unbranched stems, 5 stamens, anthers introrsely rimose (but functionally poricidal) and yellow, and globose and vinaceous capsules. The species has not had its conservation assessed yet. The information available in the herbaria indicates it flowers from November to April and produces fruits from March to April.

4.11. Dichorisandra penduliflora Kunth, Enum. Pl. [Kunth] 4: 114. 1843. Figs. 5q-r; 10q-r; 15 Herbs $15-110 \mathrm{~cm}$ tall, terrestrial. Stems ascending, apex decumbent, branched, glabrous. Leaves distichously-alternate; sheaths 0.8-2.4 $\mathrm{cm}$ long, glabrous to hispidulous, margins setose, trichomes hyaline; pseudopetiole 3-5 $\mathrm{mm}$ long, glabrous to glabrescent to hispidulous; blades 4-24.5 × 1.6-5.5 cm, elliptic to lanceolate, concolorous, green, glabrous to sparsely hispidulous on both sides, base symmetric, cuneate, apex acute to acuminate. Inflorescence terminal, pendulous, not perforating the leaf-sheath; peduncle $6-40 \mathrm{~cm}$ long; cincinni 7-22, with 2-14-flowered; cincinnus bracts $0.7-1.2 \times 0.2-0.4 \mathrm{~cm}$, linear to lanceolate, glabrous to hispidulous; bracteoles 2-3 $\times 1-3 \mathrm{~mm}$, deltoid, brown, glabrous to hispidulous. Flowers zygomorphic; pedicels 2-3 mm long, glabrous to hispidulous, trichomes hyaline; sepals 5-1.2 $\times$ 4-6 mm, ovate, hispidulous at apex, green, purple at apex; petals $0.8-1.4 \times 0.8-1.8 \mathrm{~cm}$, rhomboid to orbicular, bluish-purple to purple, basal third white; stamens 5, subequal, all pointing up; filaments 1-3 $\mathrm{mm}$ long, anthers 3-5 × 0.9-1.2 $\mathrm{mm}$, introrsely

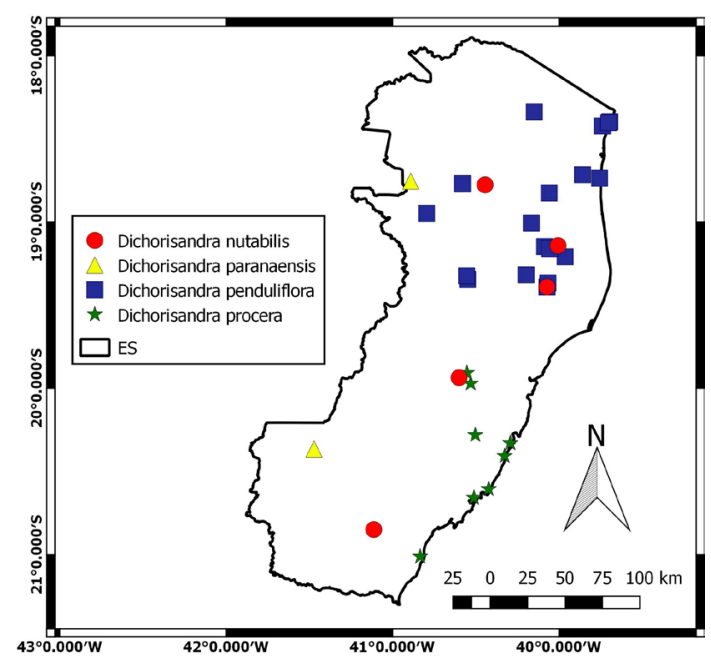

Figure 15 - Geographic distribution of Dichorisandra nutabilis, D. paranaensis, D. penduliflora, D. procera in the state of Espírito Santo. 
rimose (but functionally poricidal), white to cream with the upper half or third purple ovary $1.8-2.3 \times$ 1.5-2 mm, glabrous, style 3-5 mm long, recurved, white to cream, bluish-purple to purple at apex, stigma capitate. Capsules $1.5-4.3 \times 0.3-0.8 \mathrm{~cm}$, cylindric, smooth, curved, glabrous, green when immature, brown when mature. Seeds 4-6.5 × 1.5-2.6 mm, testa foveolate, dark brown, hilum C-shaped, embryotega semidorsal, aril opaque, white, thick, spongy.

Specimens examined: Águia Branca, assentamento 16 de abril, 10.III.2015, fl., J. Freitas 366 (VIES); 10.XII.2017, fl., Q.S. Moraes et al. 233 (VIES); 7.V.2018, fl., Q.S. Moraes et al. 297 (VIES). Água Doce do Norte, propriedade Sr Voito, 7.V.2018, fl., Q.S. Moraes et al. 235 (SAMES); 7.V.2018, fl., Q.S. Moraes et al. 238 (VIES). Aracruz, 15.V.1990, P. Vinha 1006 (CVRD, UEC); 21.II.1994, J.R. Pirani et al. 3067 (UEC, SPF). Colatina, 6.V.1934, J.G. Kuhlmann 320 (UEC, RB). Conceição da Barra, Parque Estadual de Itaúnas, 17.I.2012, fl., A.O. Giaretta et al. 1163 (VIES); trilha da Alméscar, 3.IV.2017, fl. and fr., Q.S. Moraes 158 (VIES); 3.IV.2017, fl. and fr., Q.S. Moraes 159 (VIES); 23.V.2019, fl., J. Gurtler et al. 674 (VIES). Guarapari, 23.II.1988, J.R. Pirani et al. 2445 (NY, SPF). Linhares, 10.II.1993, J.R. Pirani \& J.A. Kallunki 2765 (SPF, UEC); 12.IV.1934, J.G. Kuhlmann 180 (RB); estrada do Barro Novo, 13.V.1977, fl., G. Martinelli 2044 (RB); Reserva Biológica de Sooretama, 8.III.1972 (MBML 1409, 1411); 12.III.1972, (MBML 1415); 15.V.1977, G. Martinelli et al. 2117 (RB); 15.V.1977, G. Martinelli et al. 2131 (RB); 15.V.1977, G. Martinelli et al. 2148 (RB); 12.V.1985, G. Martinelli et al. 10981 (RB); 13.V.1977, G. Martinelli et al. 2044 (RB); 21.IV.1983, A.L. Peixoto \& H.C. Lima 1782 (RB); 21.V.1983, H.C. Lima \& A.L. Peixoto 1954 (RB); 18.X.1983, G. Hatschbach \& O. Guimarães 46961 (MBM, US); 8.IV.1984, G. Hatschbach 47731 (MBM, US); 1.II.1999, M.C.E. Carmo et al. 99/41 (CVRD, UEC); Reserva Florestal de Linhares, 2.III.1999, D.A. Folli 3366 (CVRD); 31.I.2002, P. Fiaschi et al. 958 (CVRD, SPF, UEC); 18.X.1992, D.A. Folli 1702 (CVRD); 28.I.2006, L.Y.S. Aona et al. 975 (UEC, CVRD); 28.I.2006, L.Y.S. Aona et al. 976 (UEC, CVRD); 28.I.2006, L.Y.S. Aona et al. 979 (UEC, CVRD); 14.XII.1981, H.C. Lima 1645 (RB, UEC); 13.V.1977, G. Martinelli 2041 (RB); 2.II.1985, A. Peixoto et al. 3296 (RB); 30.I.1972, D. Sucre 8274 (K, RB); 26.V.1972, A.M. Lino 63 (RB); 26.IX.1978, G. Martinelli 4973 (RB); Reserva Natural Vale, estrada flamengo, 5.IV.2006, fl. and fr., G.O. Romão et. al. 1207 (RB); Lagoa do Durão, 12.IV.1934, fl., J.G. Kuhlmann 180 (RB). São Mateus, 4.XII.1994, J.R. Pirani et al. 3363 (SPF); Liberdade, 27.II.2007, fl., A.O. Giaretta. 14 (VIES); 27.III.2010, fl., M. Ribeiro et al. 108 (VIES); 9.XII.2016, fl., Q.S. Moraes 135 (VIES); 9.XII.2016, fl., Q.S. Moraes 136 (VIES); Paulista, muçununga, 1.II.2018, fr., Q.S. Moraes 290 (RB). Santa Teresa, 25 de julho, 22.I.2018, fl., Q.S.
Moraes 305 (RB). São Roque do Canaã, 28.II.2004, A.P. Fontana et al. 785 (MBML, UEC). Vila Pavão, Córrego Grande, 23.IV.2013, fl. and fr., M.O.O. Pellegrini 375 (CEPEC, RB); norte do Rio Doce, IX.1950, J.N. Vieira 24 (RB); Sellow 384 (P).

Endemic to Brazil, being recorded for the states of Bahia and Espírito Santo (Fig. 15) (Aona et al. 2020). Dichorisandra penduliflora is easily recognized by its shrub-like habit, distichouslyalternate leaves, pendulous inflorescences, stamens 5 , anthers introrsely rimose (but functionally poricidal), cream to white with the bluish-purple to purple apex, and cylindric capsules. Morphological variation is mainly regarding the indumentum (ranging from glabrous to sparsely hispidulous) and the size of the inflorescence peduncle. $D$. penduliflora has not had its conservation assessed yet. Flowers and fruits were recorded throughout the year.

4.12. Dichorisandra procera Mart. ex Schult. f., Syst. Veg., ed. 15, 7(2): 1187.

Dichorisandra albomarginata Linden ex Regel, Gartenflora 17: 34, t. 569. 1868 三 Stickmannia albomarginata (Linden ex Regel) Kuntze, Revis. Gen. P1. 2: 721. 1891, syn. nov.

Figs. 5s-t; 15; 16a-c

Herbs 0.4-2.5 m tall., terrestrial. Stems erect, unbranched or branched in the upper third, glabrous to sparsely hispidulous, trichomes hyaline. Leaves spirally-alternate; sheaths $1-3.5 \mathrm{~cm}$ long, glabrous to sparsely hispidulous, trichomes hyaline; pseudopetiole $0.3-2 \mathrm{~cm}$ long, glabrous to sparsely hispidulous, trichomes hyaline; blades 10-38 × 2.4 $10.5 \mathrm{~cm}$, narrowly elliptic to oblong to lanceolate to elliptic to oblanceolate, discolorous, adaxially light green to green to dark green, sometimes with silver stripes in young leaves, abaxially dark green, sometimes vinaceous in young leaves, glabrous on both sides, base symmetric, cuneate to obtuse, apex acute to acuminate. Inflorescence terminal, erect, not perforating the leaf-sheath; peduncle 0.5-6 cm long; cincinni 7-35, with 3-6-flowered, cincinnus bract $0.5-15 \times 2-10 \mathrm{~mm}$, lanceolate, green, abaxially hispidulous; bracteoles $1-8 \times$ 1-4 mm, deltoid, vinaceous, abaxially sparsely hispidulous. Flowers zygomorphic; pedicels 1-7 $\mathrm{mm}$ long, glabrous to sparsely hispidulous; sepals $0.8-1.3 \times 0.4-0.7 \mathrm{~cm}$, obovate, glabrous to sparsely hispidulous at apex, bluish-purple to purple to mauve; petals $0.9-1.5 \times 1-1.5 \mathrm{~cm}$, rhomboid to obovate, bluish-purple to purple to mauve, basal third white; stamens 6 , subequal, 4 pointing to 

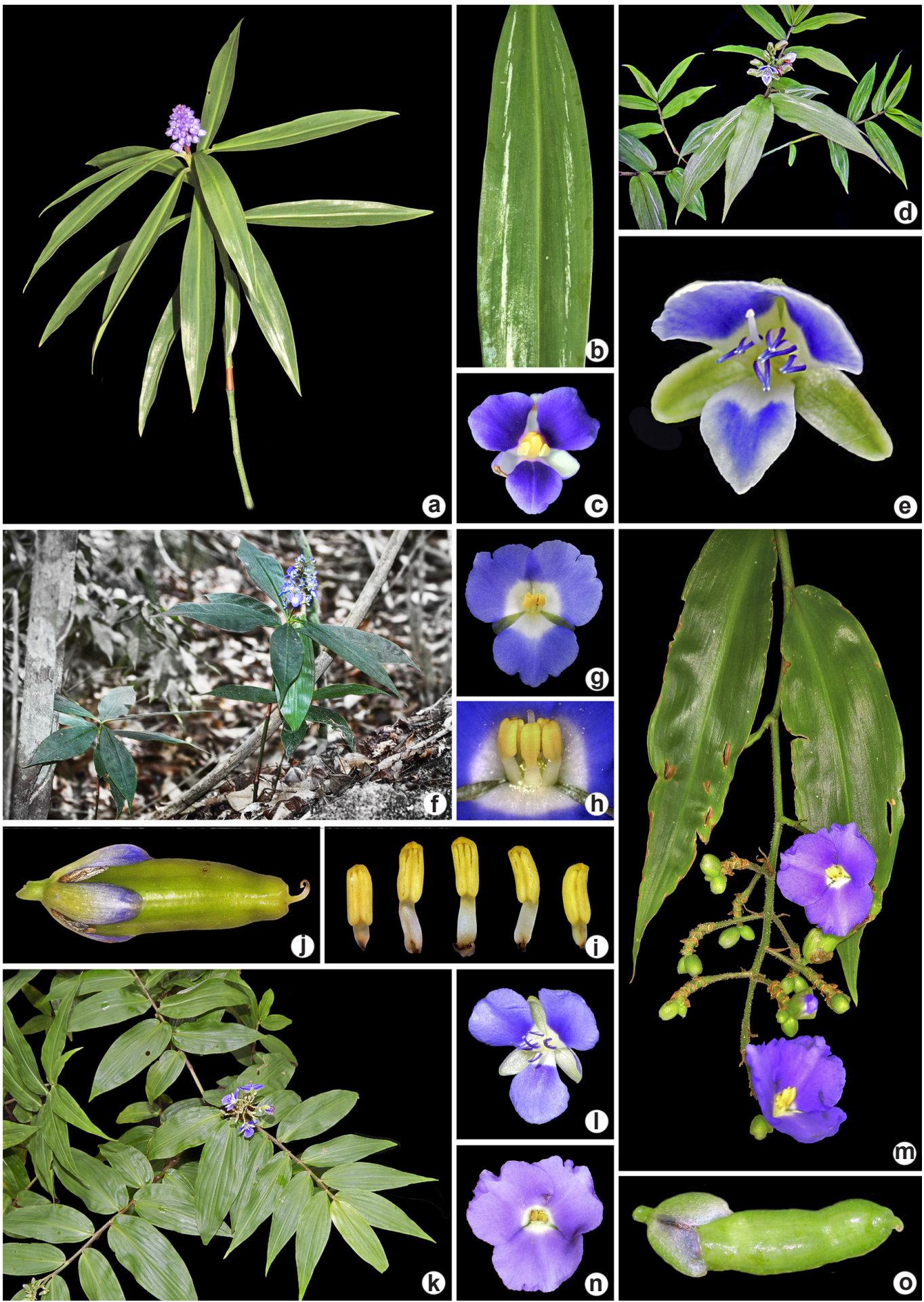

Figure 16 - a-o. Dichorisandra from the state of Espírito Santo, Brazil - a-c. D. procera - a. habit; b. adaxial side of the leaf-blade showing the longitudinal silver stripes; c. front view of a bisexual flower. d-e. D. pubescens - $\mathrm{d}$. habit; e. front view of a bisexual flower; f-j. D. striatula - f. habit; g. front view of bisexual flower; $\mathrm{h}$. androecium; i. detail of the stamens; j. immature capsule. k-1. D. tejucensis - k. habit; 1 . front view of a bisexual flower. m-o. D. velutina $-\mathrm{m}$. detail of inflorescence; o. immature capsule. (Photos a-b. MOO Pellegrini; c. F Torres; d-e. E Martins; $\mathrm{f}-\mathrm{j}, \mathrm{m}-\mathrm{o}$. QS Moraes; k-1. M Ribeiro). 
the center of the flower and 2 pointing outwards; filaments 1-4 mm long, anthers 3-7 mm long, poricidal, dehiscent by two apical pores, yellow; ovary 1-3 × 1.5-2 mm, glabrous; style 3-7 mm long, curved, white, bluish-purple to purple to mauve at apex; stigma truncate. Capsules 0.6-1 $\times 0.7-1.5 \mathrm{~cm}$, globose, green, glabrescent. Seeds 2.5-4.2 × 1.6-3.9 mm; testa scrobiculate; hilum C-shaped; embryotega semidorsal; aril opaque, white, thick, spongy.

Specimens examined: Atílio Vivaqcua, 10.III.1972, D. Sucre 8615 (RB). Castelo, Parque Estadual Mata das Flores, 4.IV.2017, fl., T.T. Carrijo 2263 (VIES); Parque Estadual Forno Grande, trilha do mirante, 16.XI.2017, fl., Q.S. Moraes et al. 282 (VIES); 16.XI.2017, fl., Q.S. Moraes et al. 283 (VIES). Cariacica, APA Monte Mochuara, Azeredo, 27.VI.2012, fl., A.M. Assis et al. 3159 (MBML). Conceição da Barra, Parque Estadual de Itaúnas, trilha do Buraco do Bicho, 13.V.2015, fl., Q.S. Moraes 35 (VIES); trilha da Alméscar, 16.I.2017, fl. and fr., Q.S.Moraes et al. 306 (VIES); 15.III.2017, fl., Q.S. Moraes 143 (VIES); 15.III.2017, fl., Q.S. Moraes 144 (VIES); 15.III.2017, fl., Q.S. Moraes 145 (VIES); 18.IV.2017, fl., Q.S.Moraes et al. 165 (VIES); areial, 24.IV.2017, fl., Q.S.Moraes et al. 166 (VIES). Domingos Martins, 19.I.1975, A.L. Peixoto et al. 459 (RB). Goitacazes, 29.III.1934, J.G. Kuhlmann 85 (RB). Guarapari, 3.IV.1984, fl. and fr., O.J. Pereira 269 (VIES); Parque Estadual Paulo César Vinha, 7.IV.2013, fl., W.C. Cardoso \& W.S. Borges 262 (VIES). Linhares, 21.II.2014, fl., L.C. Marinho 731 (CVRD). Nova Venécia, APA Pedra do Elefante, 18.IV.2015, fl., N.T.L. Pena \& L.A. Silva 264 (VIES); trilha da gameleira, 20.III.2017, fl., Q.S. Moraes et al. 148 (SAMES). Santa Leopoldina, Colina Verde, Morro do Agudo, beira da estrada, mata de grota, 16.IV.2013, fr., M.O.O. Pellegrini et al. 331 (RB); Fazenda Caioaba, propriedade Virloni, 5.I.2006, fl., L.F.S. Magnago et al. 473 (MBML); Serra do Ramalhete, 14.II.2006, fl. and fr., V. Demuner et al. 1800 (MBML). Santa Maria de Jetibá, 14.I.2003, L. Kollmann et al. 5899 (MBML). Santa Teresa, 19.II.2005, L.Y.S. Aona \& A.S.B. Gil 931 (UEC); 19.II.2005, L.Y.S.Aona \& A.S.B.Gil 932 (UEC); 19.II.2005, L.Y.S. Aona \& A.S.B. Gil 934 (UEC); 19.II.2005, L.Y.S. Aona \& A.S.B. Gil 935 (UEC); 30.I.2002, P. Fiaschi et al. 953 (SPF); 31.I.2002, L. Kollmann \& E. Bausen 5471 (MBML); 22.III.2000, $V$. Demuner et al. 843 (MBML); 15.XII.1998, L. Kollmann et al. 1319 (MBML); 20.XI.1986, H.Q.B. Fernandes 1864 (MBML); 4.III.1986, H.Q.B. Fernandes 1877 (MBML); 31.I.1986, H.Q.B. Fernandes 1820 (MBML); 12.II.2003, R.R.Vervloet et al. 1812 (MBML); 10.V.1984, J.M.Vimercat et al. 122 (MBML); 30.I.1986, W. Boone 1071 (MBML); 23.II.1999, L. Kollmann et al. 2009 (MBML); 21.I.1986, W. Boone 1041 (MBML); 13.IV.2003, R.P. Oliveira et al. 879 (HUEFS); Estação Biológica de Santa Lúcia, 13.III.1990, fl., H.Q. Boudet
Fernandes et al. 2920 (MBML); 14.II.1995, fl., C.C. Chamas (MBML 45109); 21.XI.2015, fl., M.O.O. Pellegrini \& R.F. Almeida 464 (RB); 22.XII.2016, fl., Q.S. Moraes 307 (VIES); Reserva Biológica Augusto Ruschi, Nova Lombardia, 26.III.2003, fr., R.R. Vervloet et al. 2064 (MBML). Vitória, APP Morro do Moreno, 22.VI.2012, fr., M.O.O. Pellegrini et al. 236 (RB); 22.VI.2012, fr., M.O.O. Pellegrini et al. 238 (RB, UEC, VIES).

Dichorisandra procera is endemic to Brazil, recorded for the states of Alagoas, Bahia, Pernambuco, Sergipe, Espírito Santo, Minas Gerais, and Rio de Janeiro (Aona et al. 2020). In Espírito Santo, it is found growing understory in rainforests, semideciduous seasonal forests, rocky outcrops, tabuleiro forests, and restinga (Fig. 15). A great deal of variation is accepted for this species but is mainly related to the leaves' shape and coloration. According to Aona (2008), there are no reproductive differences between $D$. albomarginata and D. procera (Figs. 5s-t; 16c), the only difference being the shape and size of the leafblades and the presence or without longitudinal silver stripes. Based on extensive field studies and the cultivation of several specimens, it become clear that these leaf characters are environmentally controlled. When a specimen with silverstripped leaves (matching the $D$. albomarginata morphotype) was relocated from a full shade greenhouse at JBRJ to a sunny greenhouse, all newly produced leaves lacked the characteristic silver stripes. After some time, the same specimen was transferred back to the full shade greenhouse and gradually started producing new leaves with silver stripes (Pellegrini, personal observation). Furthermore, during fieldwork in Espírito Santo, young specimens of $D$. procera were found with silver stripes and mature specimens with or without stripes, either in the same specimen or population (Moraes \& Pellegrini, personal observation). These leaf characters are clearly insufficient to sustain both species as distinct (Figs. 16a-b). Thus, we proposed the synonymization of $D$. albomarginata under the older D. procera. The species has not had its conservation assessed yet. Flowers and fruits were recorded throughout the year.

4.13. Dichorisandra pubescens Mart. ex Schult. f., Syst. Veg., ed. 15, 7(2): 1186. 1830.

Figs. 16d-e; 17

Herbs 40-50 cm tall., terrestrial. Stems erect, sometimes ascending with decumbent apex, branched, pilose, trichomes hyaline to light brown. Leaves distichously-alternate; sheaths $1-2.5 \mathrm{~cm}$ 
long, pilose, margins setose, trichomes hyaline to light brown; pseudopetiole 2-4 mm long, pilose, trichomes hyaline to light brown; blades 8-15.8 $\times 2.5-4.6 \mathrm{~cm}$, elliptic to lanceolate, discolorous, adaxially dark green, abaxially green, evenly pubescent on both sides, trichomes hyaline to light brown, base asymmetric, cuneate, apex acuminate. Inflorescence terminal, erect, rarely ascending, not perforating the leaf-sheath; peduncle 3-6 mm long, pilose, trichomes hyaline to light brown; cincinni 10-23, 3-6-flowered; cincinnus bract 2-3 × 1-1.5 $\mathrm{mm}$, lanceolate, green, pilose, trichomes hyaline to light brown; bracteoles 1.7-3 mm long, deltoid, pilose. Flowers zygomorphic; pedicels $2-3 \mathrm{~mm}$ long, pilose, trichomes hyaline to light brown; sepals 7-8 × 3-3.9 mm, ovate, green, densely pilose, trichomes hyaline to light brown; petals 9-10.9 × 4.5-6.8 mm, obovate, bluish-purple to purple, basal third white; stamens 6, subequal, filaments $1-2 \mathrm{~mm}$ long, anthers $2.8-3.6 \times 0.9-1.1$ $\mathrm{mm}$, poricidal, dehiscent by two pores apical, white to cream, upper half or third bluish-purple to purple; ovary $2-3 \times 2-2.8 \mathrm{~mm}$, glabrous, style 5-6 mm long, curved, white to cream, upper half or third bluish-purple to purple, stigma capitate. Capsules 7.8-10 × 3.2-6.7 mm, ellipsoid, smooth, glabrous, green, sometimes apex vinaceous. Seeds 2.9-4.2 $\times 2.3-3 \mathrm{~mm}$, testa scrobiculate, dark brown, hilum C-shaped, embryotega semidorsal, aril opaque, orange, thick, spongy.

Specimens examined: Santa Teresa, Reserva Biológica Augusto Ruschi, Nova Lombardia, 23.V.2002, fl., R.R. Vervloet et al. 283 (MBML).

Dichorisandra pubescens is recorded for Peru, Equador, Bolívia, and Brazil (Aona 2008; Aona et al. 2020). In Brazil, it occurs predominantly in the southeast region (Aona et al. 2020). In Espírito Santo, the known population is registered for the mountain region in Santa Teresa (Fig. 17). It is morphologically similar and commonly confused with $D$. hexandra but differs by its uniform indumentum throughout the plant (Aona 2008). The species has not had its conservation assessed yet. The information available in the herbaria indicates it flowers in May.

4.14. Dichorisandra striatula Q.Moraes \& M.Pell., Syst. Bot. 44(4): 783-789, f. 2-4. 2019.

Figs. 16f-j; 17

Herbs 35-60 cm tall, terrestrial. Stems erect, branched on the upper third, hispidulous, trichomes hyaline. Leaves spirally-alternate; sheaths $0.5-2.7 \mathrm{~cm}$ long, hirsutulous, margins setose; pseudopetiole $0.5-1.8 \mathrm{~cm}$ long, hirsutulous, trichomes hyaline; blades 4.7-23.1 × 3.2-9 cm, elliptic, elliptic-lanceolate to obovate, discolorous, abaxially medium to dark green, speckled with small, and discontinuous longitudinal white stripes and/or small spots, adaxially light to medium green, sometimes vinaceous in young leaves, hirsutulous on both sides, base symmetric, cuneate, apex acute to acuminate. Inflorescence terminal, erect, not perforating the leaf-sheath; cincinni 18-29, with 3-9-flowered, peduncle 0.5-2.1 cm long; cincinnus bracts 6-12 × 1.2-3.1 mm, triangular, medium brown, glabrous adaxially, shortly pilose abaxially; bracteoles 1.6-3.8 $\mathrm{mm}$ long, ovate to elliptic-lanceolate, sparsely hispidulous. Flowers zygomorphic, pedicels 1-3 $\mathrm{mm}$ long, sparsely hispid; sepals 4-6 mm long, obovate, white to purplish white, basal half green, apex lilac to purple, sparsely hirsutulous; petals 7-8 $\times 8-9 \mathrm{~mm}$, obovate to broadly obovate, purple, basal third white; stamens 5, homomorphic, all pointing up; filaments $0.6-1.3 \mathrm{~mm}$ long; anthers 2-3 mm long, introrsely rimose (but functionally poricidal), yellow; ovary 1-1.7 mm, glabrous; style 3-3.8 mm long, curved, white; stigma truncate. Capsules $1.7-2 \times 0.5-0.6 \mathrm{~cm}$, ellipsoid, glabrous, green when immature, brown when mature. Seeds 3.9-4.1 × 1.8-2 mm, testa scrobiculate; dark brown to black; hilum C-shaped; embryotega semilateral; aril slightly hyaline, white, spongy, thick, spongy. Specimens examined: Nova Venécia, Área de Proteção Ambiental Pedra do Elefante, 25.VI.2016,

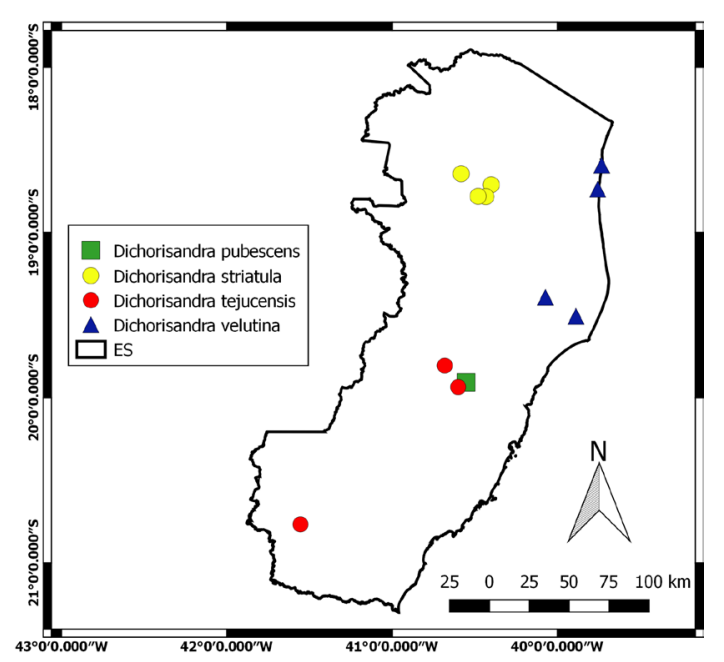

Figure 17 - Geographic distribution of Dichorisandra pubescens, D. striatula, D. tejucensis, D. velutina in the state of Espírito Santo. 
fr., Q.S. Moraes 121 (NY); 25.VI.2016, fl., Q.S. Moraes 122 (US); 25.VI.2016, fl., Q.S. Moraes 123 (CEPEC); 23.VIII.2017, fl., Q.S. Moraes 125 (SAMES); 23.VIII.2017, fl. and fr., Q.S. Moraes 126 (US; RB); 7.V.2018, fl. and fr., Q.S. Moraes 299 (RB); 7.V.2018, fl. and fr., Q.S. Moraes 300 (RB); 7.V.2018, fl. and fr., Q.S. Moraes 301 (US); 18.II.2008, fl., P. Labiak 4682 (MBML); 25.IV.2008, fl., A.M. Assis 1511 (MBML); 25.IV.2008, fl., A.M. Assis 1527 (MBML); 14.I.2009, fl., A.P. Fontana 5785 (MBML); 14.IV.2009, fl., C.N. de Fraga et al. 2517 (RB); 28.XI.2009, fl., A.M. Assis 2273 (MBML); 26.IV.2010, fl., A.M. Assis 2503 (MBML); 23.IV.2013, fl., M.O.O. Pellegrini 377 (RB); 7.V.2016, fl., A. Alves-Araújo et al. 1806 (VIES); 7.III.2016, fl., A. Alves-Araújo et al. 1809 (VIES); 7.III.2016, fl., A. Alves-Araújo et al. 1867 (VIES); 7.III.2016, fl., A. Alves-Araújo et al. 1824 (VIES); 16.III.2016, fl., R.C. Forzza 8782 (RB). Vila Pavão, 15.III.2016, fr., R.C. Forzza 8768 (RB).

Dichorisandra striatula is endemic to the municipality of Nova Venécia (Espírito Santo) (Fig. 17), being restricted to inselbergs and semideciduous forests (Moraes et al. 2019). Dichorisandra striatula is morphologically similar to D. glaziovii due to its erect stems, 5 stamens, and yellow anthers, which are introrsely rimose (but functionally poricidal). However, it differs mainly by its leaves speckled with small and discontinuous white stripes and/or spots on the adaxial side, hirsutulous on both sides (Fig. 16f) (vs. broad stripes which are continuous on the adaxial sides, hispidulous on both sides), petals obovate to broadly obovate (Fig. 16g) (vs. petals rotund to broadly rhomboid) and fruits ellipsoid (Fig. 16j) (vs. fruits cylindric). According to Moraes et al. (2019), D. striatula should be considered Endangered (EN). Flowers were recorded from January to July, and fruits were recorded from January to March, July, and August.

4.15. Dichorisandra tejucensis Mart. ex Schult. f., Syst. Veg., ed.15, 7(2): 1186. 1830.

Figs. 16k-1; 17

Ervas 0.7-1.5 m tall, terrestrial. Stems erect, branched in the upper half, sericeous, trichomes hyaline. Leaves distichously-alternate; sheaths 3-5 cm long, hispid, margins setose; pseudopetiole 1-3.5 mm long to inconspicuous, hispid, trichomes hyaline; blades $10-15.6 \times 3.8-6 \mathrm{~cm}$, oblanceolate, discolorous, adaxially dark green, glabrescent, abaxially light green to green, densely pilose, congested along the veins, base asymmetric, round to cuneate, apex acuminate. Inflorescence terminal, erect, not perforating the leaf-sheath; peduncle 4-6 cm long; cincinni 9-23, 3-7-flowered; cincinnus bract $0.7-3 \times 0.2-0.5 \mathrm{~mm}$, lanceolate, greenish, hispid; bracteoles 2.5-3.8 mm long, deltoid, brown, hispid. Flowers zygomorphic; pedicels 2-3 mm long, hispid; sepals 7-9.5 × 3-4.7 mm, ovate, green, margins bluish-purple, glabrous; petals 9-13 × 7-12 mm, obovate, bluish-purple to purple, basal third white; stamens 6 , subequal, all pointing up; filaments $0.8-1.2 \mathrm{~mm}$ long, anthers $3.7-5 \times 0.9-1.2 \mathrm{~mm}$ long, poricidal, dehiscent by two apical pores, white to cream, upper half or third bluish-purple to purple; ovary $1-2 \times 0.8-1.7 \mathrm{~mm}$, glabrous, style $6-8 \mathrm{~mm}$ long, slightly recurved, base white, bluish-purple to purple at apex, stigma truncate. Capsules 7-9 × 6-7 mm, subglobose to globose, glabrous, smooth, green. Seeds 2.5-2.9 $\times$ 1.5-2.6 mm, testa scrobiculate, dark brown, hilum C-shaped, embryotega semidorsal, aril opaque, orange, thick, spongy.

Specimens examined: Alegre, Arie Laerth Paiva Gama, fl., 9.II.2008, D.R. Couto 448 (MBML). Itarana, Limoeiro de Santo Antônio, 20.I.2010, fl., V.B. Sarnaglia Jr 188 (VIES). Santa Teresa, São João de Petrópolis, E.A.F.S.T., 11.XII.1985, fl., W. Boone 968 (MBML); Instituto Federal do ES, 20.I.2011, fl. and fr., P. Fiaschi et al. 3497 (MBML, RB); 21.XII.2011, fl., J. Gurtler et al. 5 (MBML); 21.I.2012, fl., J. Gurtler et al. 57 (MBML); 1.II.2012, fl., J. Gurtler et al. 68 (MBML); 8.II.2012, fl., J. Gurtler 85 (MBML); Valão de São Brás, 6.II.2013, fl., V.B. Sarnaglia Jr et al. 647 (VIES, RB). Viana, Jucuruaba, 4.IV.2014, fl., M. Ribeiro 993 (VIES).

Dichorisandra tejucensis is native and endemic to Brazil, occurs in Espírito Santo (Fig. 17), Minas Gerais, Rio de Janeiro and São Paulo (Aona et al. 2020). Commonly found in the Seasonally dry forests and Ombrophilous Atlantic Forests Brazilian. Densely hispid leaf-blades along the veins and 6 stamens with poricidal dehiscing in two apical pores are the most important diagnostic morphological characters to recognize it (Fig. $16 \mathrm{k}-1)$. The species has not had its conservation assessed yet. The information available in the herbaria indicate flowering from November to February.

4.16. Dichorisandra velutina Aona \& M.C.E. Amaral, Phytotaxa 48:15. 2012. Figs. 16m-o; 17 Herbs 30-100 cm tall., terrestrial. Stems erect to scrambling, branched, sparsely hispid, trichomes hyaline. Leaves distichously-alternate; sheaths 1-3.5 cm long, hispid, margins hispid, trichomes hyaline; pseudopetiole 2-6 mm long, hispidulous, trichomes hyaline; blades 4-24 × 2-4.8 cm, lanceolate to elliptic to oblanceolate, discolorous, 
adaxially dark green to green, abaxially light green, velutine on both sides, sometimes glabrescent, trichomes hyaline, base asymmetric, cuneate to round, apex acuminate. Inflorescence terminal, ascending to patent or pendulous, not perforating the leaf-sheath; peduncle $0.8-7 \mathrm{~cm}$ long, densely velutine, trichomes hyaline; cincinni $8-18$, 3-7-flowered; cincinnus bract 2-14 × 1.5-2.5(-10) $\mathrm{mm}$, deltoid, brown, velutine, trichomes hyaline; bracteoles 1-4 mm long, deltoid, brown, velutine, trichomes hyaline. Flowers zygomorphic; pedicels 1-2 mm long, velutine, trichomes hyaline; sepals 7-10 $\times 5-7 \mathrm{~mm}$, obovate, green, velutine, trichomes hyaline; petals $7-13 \times 8-15 \mathrm{~mm}$, orbicular, lilac to purple with a white basal third; stamens 5, subequal, all pointing up; filaments $1-2 \mathrm{~mm}$ long, anthers 3-4 × 1-1.3 mm long, introrsely rimose (but functionally poricidal), pale yellow; ovary $1-1.5 \times$ 0.8-1.3 mm, glabrous, style 3-5 mm long, slightly recurved, white at base, bluish-lilac to lilac upper half or third, stigma truncate. Capsules 1.2-3 $\times$ 0.5-0.7 cm, ellipsoid, smooth, curved, glabrous, green when immature, brown when mature. Seeds 5-6 $\times 2.5-4 \mathrm{~mm}$, testa scrobiculate, dark brown, hilum C-shaped, embryotega semidorsal, aril opaque, white, opaque.

Specimens examined: Aracruz, Rio Comboios, entre Barra do Riacho e Vila do Riacho, próx. à fábrica de asfalto da Aracruz Celulose, fr., 11.V.1987, H.C. Lima et al. 2940 (K, RB). Conceição da Barra, Parque Estadual de Itaúnas, 9.I.2008, fl., M.M. Saavedra et al 609 (MBML); trilha da borboleta, 15.III.2017, fl., Q.S. Moraes 138 (VIES); trilha da alméscar, 15.III.2017, fl., Q.S. Moraes 139 (MBML); 15.III.2017, f1., Q.S. Moraes 140 (SAMES); 15.III.2017, fl., Q.S. Moraes 141 (SAMES); 15.III.2017, fl., Q.S. Moraes 142 (VIES); 22.V.2017, fr., Q.S. Moraes 241 (VIES); 22.V.2017, fr., Q.S. Moraes 242 (VIES). Linhares, Reserva Florestal da Cia. do Vale do Rio Doce, 17.I.1975, fl., A.L. Peixoto 383 (RB); 10.V.1977, fl., G. Martinelli et al. 1882 (RB); Travessa XII-Piraju, 20.IV.1983, fl., C. Farney et al. 268 (RB, UEC, HERB); 10.V.1990, fl., D.A. Folli 1127 (CVRD, UEC, HERB); 10.I.1992, fl. and fr., G.L. Farias 484 (CVRD, HURB, RB, UEC); 10.I.1992, fl., G.L. Farias 485 (CVRD, HURB, RB, UEC); 2.IV.1997, fl. and fr., D.A. Folli et al. 2970 (CVRD, HURB, UEC); 1.II.1999, fl., M.C.E. Amaral et al. 99/44 (CVRD, UEC); estrada de Linhares para o Pontal do Vale, c. 8,1 km após o viaduto, ramal à direita para Povoação, 4.III.2004, fl., P. Fiaschi et al. 2007 (SPF, CEPEC); 17.I.1975, fl., A.L. Peixoto \& O.L.Peixoto 383 (RB); estrada Flamengo, 28.I.2006, fl. and fr., L.Y.S. Aona 975 (RB); 4.IV.2019, fl., J. Cordeiro et al. 6174 (MBM). São Mateus, Guriri, 12.III.1972, fl. (MBML 1413); 10.III.1972, fl. (MBML 1410, 1412).
Dichorisandra velutina is endemic to Espírito Santo (Fig. 17), growing understory in rainforests, tabuleiro forests, and restinga (AonaPinheiro \& Amaral 2012; Aona et al. 2020). The leaves are usually velutine, but specimens from restingas can have glabrescent leaves. According to Aona-Pinheiro \& Amaral (2012), D. velutina is categorized as Vulnerable (VU). Flowers were recorded from December to May, and fruits from January to May.

\subsection{Dichorisandra sp.}

Fig. 18

Herbs 18-26 cm tall., terrestrial. Stems erect to decumbent, pubescent. Leaves spirally-alternate; sheaths $1.5-2.5 \mathrm{~cm}$ long, hirsute, margins hirsute, trichomes rusty-brown; pseudopetiole $1-3.4 \mathrm{~cm}$ long, hirsute; blades $4.5-14 \times 2-3.9 \mathrm{~cm}$, elliptic to lanceolate, discolorous, adaxially green, sometimes with brown to reddish-brown variegation, abaxially light green, sometimes vinaceous in young leaves, hirsute on both sides, trichomes rusty-brown, base symmetric, cuneate, apex acuminate. Inflorescence basal, erect, perforating the leaf-sheath; peduncle 2.8-4.4 cm long hirsute, trichomes rusty-brown; cincinni 1-2, 4-9-flowered; cincinnus bracts 10-12 $\times 2-2.5 \mathrm{~mm}$, lanceolate, hirsute, trichomes rustybrown; bracteoles 5-6 mm long, hirsute, trichomes rusty-brown. Flowers zygomorphic, pedicels 6-11 $\mathrm{mm}$ long, hirsute, trichomes rusty-brown; sepals 8-11 × 2-4.5 mm, white, apex purple, hirsute, trichomes rusty-brown; petals 6-9 × 3.5-4.5 mm, obovate, white; stamens 6 , dimorphic (the posterior with large and connivent anthers, the anterior with small and free anthers), filaments $1.5-2 \mathrm{~mm}$ long, posterior anthers-3 4-4.5 mm long, poricidal, dehiscent by one apical pore, yellow, anterior anthers-3, 1.8-2 mm long, poricidal, dehiscent by one apical pore, pale yellow; ovary $2.5 \times 2 \mathrm{~mm}$, hirsute; style $6 \mathrm{~mm}$ long, erect; stigma truncate. Capsules 9-6 × 5-5.5 mm, ovoid, hirsute, brown. Seeds 4-6 × 2-2.3 mm, testa scrobiculate, dark brown, hilum C-shaped, embryotega semilateral, aril hyaline, white, thin.

Specimens examined: Cariacica, Reserva Biológica de Duas Bocas, 16.II.2008, fr., C.N. Fraga 1872 (RB). Santa Leopoldina, Fazenda Sete Quedas, Rio Prata, 17.I.2000, fl., C.M. Sakuragui et al. 919 (HUEM).

Dichorisandra sp. is endemic to the Duas Bocas Biological Reserve, in Cariacica and Estrada Leopoldina, in Santa Leopoldina (Espírito Santo) (Fig. 18). It is similar to D. neglecta due to its inflorescences perforating the leaf-sheaths, white petals, and stamens dimorphic. However, it can 
be easily distinguished by its leaves sometimes with brown to reddish-brown variegation adaxially (vs. always green in D. neglecta), inflorescence basal (vs. axillary), anthers poricidal (vs. rimose but functionally poricidal), and hirsute ovary (vs. glabrous).

5. Floscopa glabrata (Kunth) Hassk. Commelin. Ind. 166. 1870 .

Figs. 18; 19a-d

Herbs 30-40 cm tall, perennial, aquatic or paludal. Roots fibrous, without terminal tubers. Stems erect, branched, red, setose, trichomes hyaline, monomorphic when flowering. Leaves spirally-alternate; sheaths 0.6-1 cm long, pubescent, margins setose; pseudopetiole 3-6 mm long, pubescent, trichomes hyaline; blades 3.5-11 $\times 0.7-2 \mathrm{~cm}$, elliptic to lanceolate, concolorous, green, adaxially scabrid, abaxially pubescent, base symmetric, cuneate to round, apex acute to acuminate. Inflorescence terminal, erect; peduncle 1-2.5 com long; cincinni solitary, alternate, 6-11-flowered; cincinni bracts 2.5-6 $\times 0.5-0.8 \mathrm{~cm}$, leaf-like, lanceolate, green, pubescent; bracteoles 1-1.8 × 0.7-1.1 mm, rhomboid, light brown, pubescent. Flowers enantiostylous; hook-trichomes absent; pedicels 0.7-1.2 mm long, pubescent; sepals $1.5-3 \times 1-2 \mathrm{~mm}$, oblong, mauve to lilac to purple, sometimes green at base, pubescent; petals $1.8-2.5 \times 1-1.5 \mathrm{~mm}$, equal, oblong, lilac or pink; stamens 6, dimorphic, filaments 2-3.5 mm long, glabrous anthers $0.5-0.8 \mathrm{~mm}$ long, rimose, yellow; lacking staminodes; ovary $0.3-0.6 \times 0.3-0.5 \mathrm{~mm}$,

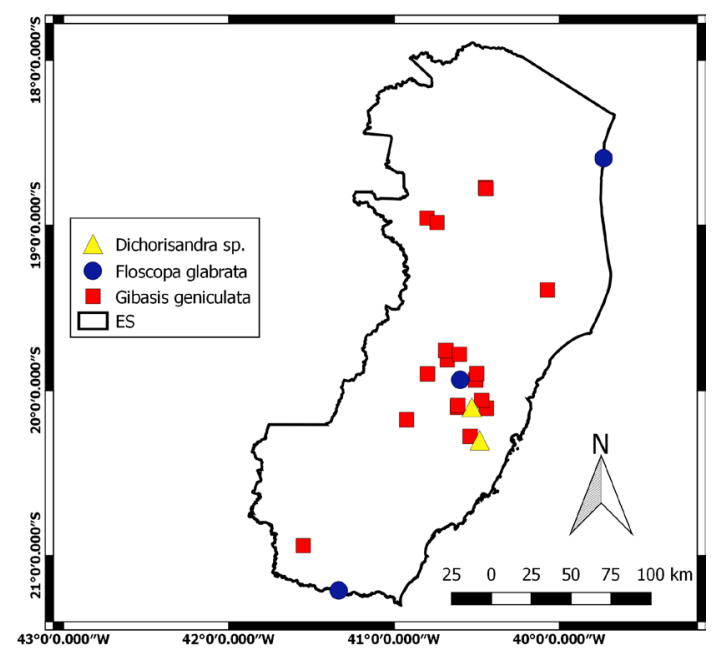

Figure 18 - Geographic distribution of Dichorisandra sp., Floscopa glabrata, Gibasis geniculata in the state of Espírito Santo. glabrous, style 2-4 mm long, curved, stigma truncate. Capsules 1.8-2.5 × 2.7-4 mm, 2-valved, obcordate, thin-walled, light brown, glabrous. Seeds $1-1.3 \times 1.2-1.5 \mathrm{~mm}$, testa costate, brown, hilum linear, embryotega dorsal, discolorous with the testa.

Specimens examined: Conceição da Barra, Reserva Biológica Córrego Grande, estrada interna, 19.III.2011, fl. and fr., I.S. Broggio \& M. Ribeiro $196 b$ (VIES, SAMES). Mimoso do Sul Muqui, Morro Bom Retiro, 23.IV.1972, fl., D. Sucre 8912 (RB); Fazenda São Bento, 8.IV.2001, fl., F.B. Pereira 54/86 (RFA). Santa Teresa, Estação Santa Lúcia, fl. (BHCB 31411); 13.XII.2017, fl., Q.S. Moraes 287 (VIES).

Endemic to South America, occurring in Brazil, Argentina, and Paraguay. In Brazil, there are records from Amazonas, Pará, Rondônia, Tocantins, Bahia, Ceará, Maranhão, Paraíba, Pernambuco, Piauí, Espírito Santo (Fig. 18), Minas Gerais and Rio de Janeiro. Floscopa glabrata is very frequent in humid places, along the margins of rivers, or as an emergent herb (Aona et al. 2020). In Espírito Santo, the specimens differ by their red stems (Fig. 4f). However, species delimitation in Floscopa is poorly understood, and further taxonomic studies are still necessary to elucidate these boundaries. The species has not had its conservation assessed yet. Flowers and fruits were recorded throughout the year.

6. Gibasis geniculata (Jacq.) Rohweder Abh. Auslandsk., Reihe C, Naturwiss. 18: 143. 1956.

Figs. 4g; 18; 19e-h

Herbs 20-40 cm tall, perennial ou annual, terrestrial or rupicolous. Roots fibrous, without terminal tubers. Stems creeping to ascending at the apex, branched, densely villose to pubescent, trichomes hyaline, monomorphic when flowering. Leaves distichously-alternate; sheaths $0.4-1.2 \mathrm{~cm}$ long, lanate, margins lanate; sessile; blades 2.4-9.8 $\times 1.2-3.5 \mathrm{~cm}$, ovate to obovate, concolorous, green with margins vinaceous, adaxially villose to pubescent, abaxially glabrous to lanate, base asymmetric, round, apex acuminate. Inflorescence terminal, erect; peduncle 2-7 cm long; cincinni 2, subopposite; cincinni 4-7-flowered; cincinnus bracts $1-2 \mathrm{~mm}$ long, free from the cincinnus peduncle, linear, green; bracteoles inconspicuous. Flowers actinomorphic; hook-trichomes absent; pedicels 7-10 mm long, glandular-pubescent; sepals $2.5-5 \times 2-3 \mathrm{~mm}$, elliptic, green, densely villose to pubescent; petals $3-4.5 \times 1.8-2.5 \mathrm{~mm}$, equal, ovate, white; stamens 6 , homomorphic, filaments $2-3 \mathrm{~mm}$ long, bearded at the middle 


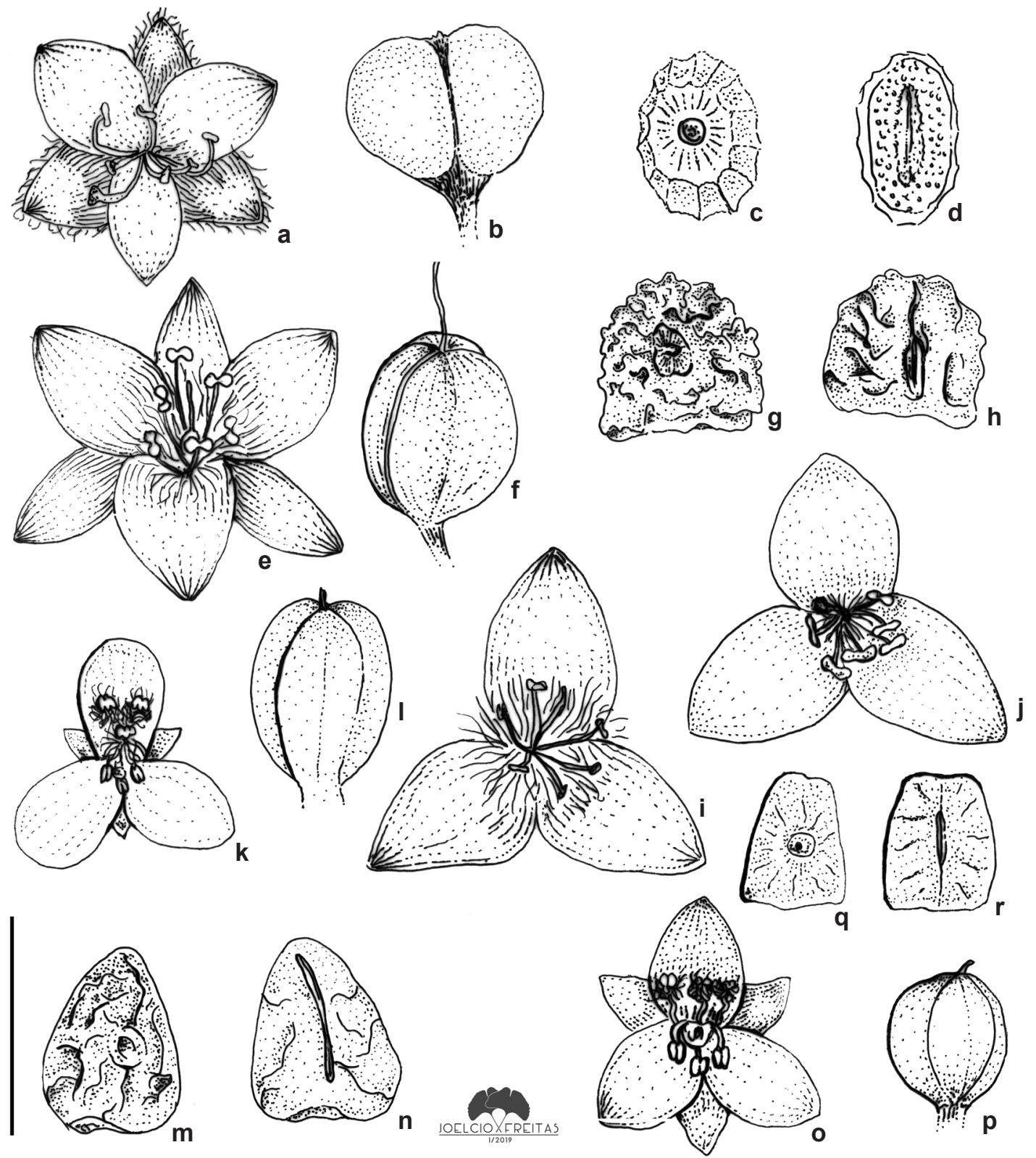

Figure 19 - a-d. Floscopa glabrata - a. front view of a bisexual flower; b. immature capsule; c-d. seed showing the costate ornamentation; c. detail of dorsal embryotega; d. details of the linear hilum. e-h. Gibasis geniculata - e. front view of a bisexual flower; f. immature capsule; $g$-h. seed showing the scrobiculate ornamentation $-\mathrm{g}$. detail of dorsal embryotega; h. details of the linear hilum. i. Tradescantia fluminensis - front view of a bisexual flower. j. Tradescantia zebrina - front view of a bisexual flower. k-n. Tripogandra diuretica - k. front view of a bisexual flower; 1. immature capsule; $m-n$. seed showing the scrobiculate to ribbed ornamentation; $m$. details of punctiform hilum; n. detail of dorsal embryotega. o-r. Tripogandra warmingiana - o. front view of a bisexual flower; p. immature capsule. q. details of dorsal embryotega. r. details of linear hilum. Scale bars: $a=4 \mathrm{~mm} ; \mathrm{b}, \mathrm{f}=3.5 \mathrm{~mm} ; \mathrm{c}, \mathrm{d}=1.75$ $\mathrm{mm} ; \mathrm{e}=5 \mathrm{~mm} ; \mathrm{f}=3.75 \mathrm{~mm} ; \mathrm{g}, \mathrm{h}=3 \mathrm{~mm} ; \mathrm{i}=6 \mathrm{~mm} ; \mathrm{j}=6.5 \mathrm{~mm} ; \mathrm{k}=12 \mathrm{~mm} ; \mathrm{l}=4.5 \mathrm{~mm} ; \mathrm{m}, \mathrm{n}, \mathrm{q}$ and $\mathrm{r}=2.5 \mathrm{~mm}$; o $=8$ mm; p $=4$ mm. (a-d. Moraes 287; e-h. Moraes 147; i. Moraes 281; k-n. Carrijo 2268; o-p. Pellegrini 346). Line drawings by J Freitas. 
with moniliform trichomes, anthers $0.3-0.5 \times$ 0.5-0.6 mm, rimose, yellow; staminodes absent; ovary $0.8-1 \times 0.5-0.7 \mathrm{~mm}$, glabrous, style $2-2.5$ $\mathrm{mm}$ long, erect, stigma truncate. Capsules 2.5-4 $\times$ 2-3 mm, globose, thin-walled, green, glabrous. Seeds $1.5-2 \times 1.2-1.5 \mathrm{~mm}$, testa rugose, brown, hilum linear, embryotega dorsal, concolorous with the testa.

Specimens examined: Linhares, 7.I.1993, fl., D.A. Folli 1777 (CVRD); 7.VII.2005, fl., G.S. Siqueira 185 (CVRD); entrada para o Juncado, 7.V.2009, fl., P.J.M. Maas 9820 (CVRD). Mimoso do Sul, Conceição do Muqui, Pontões, 8.VII.2004, fl., L. Kollmann 6822 (MBML). Nova Venécia, APA Pedra do Elefante, trilha da gameleira, 20.III.2017, fl., Q.S. Moraes et al. 147 (VIES); trilha principal para a gameleira, 20.III.2017, fl., Q.S. Moraes et al. 152 (RB); 20.III.2017, fl., Q.S. Moraes et al. 153 (RB); 20.III.2018, fl., Q.S. Moraes et al. 304 (VIES). Santa Maria de Jetibá, Pedra do Garrafão, 21.IV.2003, fl., L. Kollmann 6121 (MBML). Santa Teresa, São João de Petrópolis, 10.V.2000, fl., $V$. Demuner 1019 (MBML); Rio Saltinho, Santa TeresaFundão, 29.V.2001, fl., L. Kollmann 3724 (CVRD); Várzea Alegre, cachoeira do Madalão, 30.VIII.2001, fl., L. Kollmann, 4451 (CVRD); Bela Vista, 20.IV.2005, fl., A.P. Fontana 1346 (MBML). São Roque do Canaã, Pedra do Pionte, São Bento, 28.II.2004, fl., A.P. Fontana 758 (MBML).

Gibasis geniculata is the most widespread species of the genus, extending from Mexico to Paraguay and Argentina (Hunt 1986b). It is broadly distributed in Brazil (Aona et al. 2020). In Espírito Santo, it is recorded in humid places from seasonally dry forests (Fig. 18). It is easily distinguished from other species by its generally lanate leaves and white petals. Gibasis geniculata has not had its conservation assessed yet. Flowers and fruits were recorded throughout the year, but mainly from May to July.

7. Siderasis Raf., F1. Tellur. 3: 67. 1837; emend. M.Pell. \& Faden, PhytoKeys 83: 6. 2017.

Herbs or vines, perennial, rupicolous or terrestrial. Roots tuberous. Stems erect or vining, branched or not, trichomes hirsute, rusty or hyaline, monomorphic when flowering. Leaves distichously- or spirally-alternate; sheaths with margins hispid, sessile or pseudopetiolate. Inflorescence reduced to a solitary cincinnus or a many-branched thyrse with alternate cincinni, terminal or axillary, and bracteoles present. Flowers zygomorphic; hook-trichomes absent; sepals, unequal, free; petals, equal to subequal, blue to purple or white, free; stamens 6, filaments glabrous, anthers extrorsely rimose, dorsifixed, anther sacs divergent, C-shaped, 3 to 4 times shorter than the filaments, connectives expanded, staminodes absent; ovary 3-locular, globose to oblongoid, style erect or curved, stigma capitate or truncate. Fruit capsule loculicidal, globose or oblongoid, thickwalled. Seeds arillate, brown, hilum C-shaped, embryotega semidorsal to semilateral, concolorous with the testa.

Siderasis comprises six species endemics to the Atlantic Forest of Brazil, with three species recorded for Espírito Santo (Pellegrini \& Faden 2017). The genus is characterized by its rusty hirsute indumentum covering the entire plant, short stems, flowers emerging from the roots, petals basally connate (Pellegrini \& Faden 2017).

\section{Key to the species of Siderasis of the state of Espírito Santo}

1. Stems vining; leaves distichously-alternate, base asymmetric; inflorescences axillary and terminal, a many-branched thyrse; flowers zygomorphic, petals white 7.3. Siderasis zorzanellii

1'. Stems erect; leaves spirally-alternate, base symmetric; inflorescences terminal or apparently so, reduced to a solitary cincinnus; flowers actinomorphic, petals purple to bluish-purple .....

2. Leaf-blades adaxially with a thin white stripe along the midvein; flowers pedicellate, petals with a white basal third, anthers bluish-purple to purple. 7.1. Siderasis albofasciata

2'. Leaf-blades adaxially lacking a white stripe; flowers sessile, petals lacking a white basal third, anthers white 7.2. Siderasis medusoides

7.1. Siderasis albofasciata M.Pell., Nordic J. Bot. 35(1): 30. 2016. Fig. 4j-k; 20

Herbs $10-15 \mathrm{~cm}$ tall. Stems erect, unbranched, flagelliform-shoots, lanate, trichomes brown and hyaline. Leaves spirally-alternate; sheaths $0.5-1.3$ $\mathrm{cm}$ long, vinaceous, lanate, trichomes light brown to rusty; pseudo petiole $1-2.7 \mathrm{~cm}$ long to sessile; blades (4.5-4.8-)10-15.8 × (3.1-3.5-)4.4-7.2 cm, elliptic to obovate, rarely lanceolate, succulent, adaxially dark green, with a thin white stripe 
along the midvein, hispid, trichomes light brown to hyaline, abaxially vinaceous to atro-vinaceous, lanate, trichomes light brown, base symmetric, slightly subcordate to cuneate, vinaceous, apex acute. Inflorescence terminal, erect; peduncle 4-9 mm long; cincinnus solitary, appressed and short; cincinnus 3-8-flowered; cincinnus bract 3.3-6 $\times$ 2.2-4.6 mm, bracteose, triangular, vinaceous, hispid, trichomes rusty; bracteoles 2.9-4.4 × 2.8-3.2 mm, broadly ovate to depressed ovate, vinaceous to pinkish-purple, sparsely hispid, trichomes rusty. Flowers actinomorphic; pedicels 1-7.2 mm long, hispid, trichomes rusty; sepals $0.9-1.1 \times 0.4-0.7$ $\mathrm{cm}$, narrowly ovate to elliptic, white to light green, sparsely hispid, trichomes hyaline to rusty; petals $1-1.6 \times 0.9-1.2 \mathrm{~cm}$, ovate, bluish-purple to purple, basal third white; stamens homomorphic, filaments 5-7.1 mm long, anthers 1.5-2.3 mm long, bluishpurple to purple; ovary $1-2 \times 1-2 \mathrm{~mm}$, densely hispid, trichomes hyaline, style 4.1-6.3 mm long, straight, stigma truncate. Capsules $1-1.3 \times 0.7-0.9$ $\mathrm{cm}$, subglobose to broadly oblongoid, green when immature, light brown when mature, hispid, trichomes rusty. Seeds 3.3-5.2 × 2.4-2.9 mm, testa rugose, dark brown, hilum $\mathrm{C}$-shaped, embryotega semilateral, aril slightly translucent, cream, thick.

Specimens examined: Fundão Piabas, propriedade de Albino Cassimiro, 8.II.2007, fl., A.P. Fontana 2827 (RB). Santa Teresa, Museu de Biologia Mello Leitão, Casa das Epífitas, 13.IX.1989, fl., W. Boone 1349 (MBML); Julião, propriedade de João Luiz Rodrigues de Souza, 23.II.2007, fl., A.P. Fontana 2975 (MBML, RB); Cabeceira do 25 de Julho, Julão, 10.XII.2009, fl., L. Kollmann et al. 11839 (RB); Alto Julião, Fazenda Novo Triunfo, propriedade Florinda, 18.IV.2013, fr., M.O.O. Pellegrini 337 (MBML, $\mathrm{RB})$.

Siderasis albofasciata is endemic to Santa Teresa and Fundão (Espírito Santo, Fig. 20) (Pellegrini \& Faden 2017). It can be differentiated by its sessile to pseudo petiolate leaves covered by hyaline to light brown indumentum, with a white stripe along the midvein on the leaf-blade's adaxial side producing flagelliform-shoots, and its bluishpurple to purple anthers (Fig. 4h-i) (Pellegrini 2017b; Pellegrini \& Faden 2017). According to Pellegrini (2017b), S. albofasciata should be considered Critically Endangered (CR). It flowers from November to February and produces fruits in April.

\subsection{Siderasis medusoides M.Pell. \& Faden, PhytoKeys 83: 27. $2017 . \quad 4 h-\mathrm{i} ; 20$ \\ Herbs 5-10 cm tall. Stems erect, unbranched, flagelliform-shoots absent, sparsely lanate, trichomes brown to hyaline. Leaves spirally-}

alternate, membranous appressed to the soil; sheaths 0.8-1.4 cm long, green, hispid, trichomes hyaline to light brown; pseudopetiole $0.5-4 \mathrm{~mm}$ long, hispid, trichomes light brown to hyaline; blades 10-24.4 $\times 3.7-11.5 \mathrm{~cm}$, elliptic, membranous, discolorous, adaxially green, abaxially green to vinaceous, hispid on both sides, trichomes light brown to hyaline, base symmetric, cuneate, apex obtuse. Inflorescence terminal, erect; peduncle 5.6-12.7 mm long; cincinnus solitary, tangled and elongate; cincinnus (5-)8-26-flowered; cincinnus bract 2.4-4.9 × 1.5-4 $\mathrm{mm}$, leaf-like, ovate, green, hispid, trichomes rusty; bracteoles $0.9-1.5 \times 0.8-1.3 \mathrm{~mm}$, deltoid, green, hispid. Flowers actinomorphic, sessile; sepals 3.5$6.7 \times 2-3.6 \mathrm{~mm}$, elliptic to obovate, green to purple, sparsely hispid, trichomes light brown to rusty; petals $4.4-10.1 \times 1.7-6.7 \mathrm{~mm}$, elliptic to narrowly obovate to spathulate, bluish-purple to dark blue; stamens homomorphic, filaments $2.5-3.5 \mathrm{~mm}$ long, anthers $0.8-1 \mathrm{~mm}$ long, white; ovary $1.2-1.9 \times 1-1.5$ $\mathrm{mm}$, densely hispid, trichomes hyaline, style 1.3-4.5 $\mathrm{mm}$ long, straight, stigma truncate. Capsules 6.8-9.4 $\times$ 6.7-7.8 mm, oblongoid to broadly oblongoid, green when immature, brown when mature, hispid, trichomes rusty. Seeds 3.6-4.1 $\times 2.6-3.2 \mathrm{~mm}$, testa rugose, dark brown, hilum C-shaped, embryotega semilateral, aril slightly translucent, cream, thick.

Specimens examined: Marilândia, Liberdade, propriedade Deoclécio Lorenccini, 22.III.2007, fl. and fr., V. Demuner 3429 (MBML); propriedade Sônia e Reinaldo Bautz, 10.XII.2007, fl., V. Demuner 4682 (MBML). Santa Leopoldina, Colina Verde, Morro do Agudo, propriedade

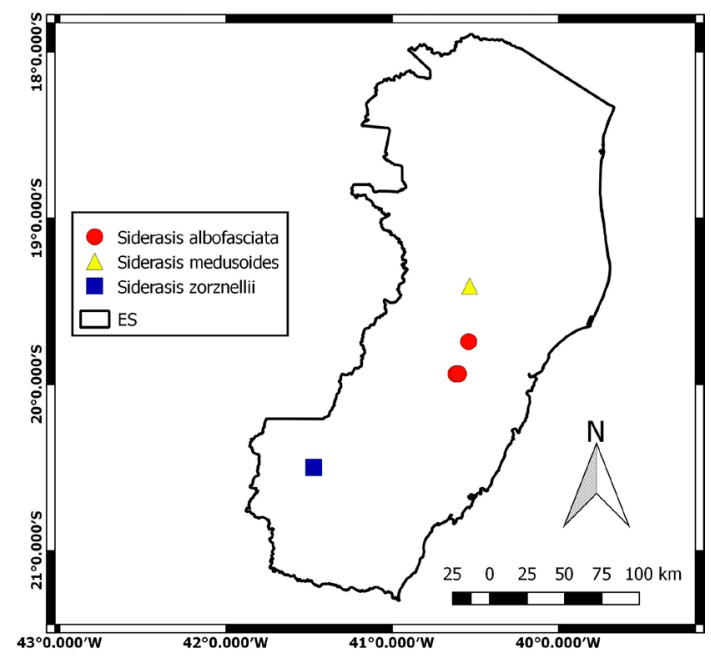

Figure 20 - Geographic distribution of Siderasis albofasciata, $S$. medusoides, $S$. zorzanellii in the state of Espírito Santo. 
Israel Elias Ramos, trilha da casa, 13.III.2007, fl., $V$. Demuner 3118 (MBML).

Siderasis medusoides is endemic to Marilândia and Santa Leopoldina (Espírito Santo, Fig. 20) (Pellegrini \& Faden 2017). It is characterized mainly by its membranous leaves appressed to the soil, tangled and elongate cincinni, small flowers, and bluish-purple to dark blue petals (Fig. 4jk). According to Pellegrini \& Faden (2017), $S$. medusoides is categorized as Critically Endangered (CR). The information available in the herbaria indicate flowering from December to March and fruits from January to March.

7.3. Siderasis zorzanellii M.Pell. \& Faden, PhytoKeys 83: 34. $2017 . \quad$ Fig. 41-n; 20

Vining herbs 1-3 $\mathrm{m}$ tall. Stems vining, scandent, branched, flagelliform-shoots absent, velutine, trichomes brown to hyaline. Leaves distichously-alternate; sheaths $2-2.7 \mathrm{~cm}$ long, green, velutine, trichomes hyaline to brown; pseudopetiole 2-3.5 mm long, green, velutine, trichomes hyaline to brown; blades $4-12.7 \times 1-2.8 \mathrm{~cm}$, elliptic to lanceolate, chartaceous concolorous, green, velutine on both sides, trichomes light brown to hyaline, base asymmetric, cuneate, apex acuminate. Inflorescence terminal and axillary, erect; peduncle $0.9-1.2 \mathrm{~cm}$ long; cincinni 12-20, (1-)2-5-flowered; manybranched thyrse with alternate cincinni, appressed and short; cincinnus bracts 2.5-15.3 × 1.4-2 mm, leaf-like, triangular, green, hispid, trichomes hyaline; bracteoles $0.9-1.5 \times 0.8-1.3 \mathrm{~mm}$, deltoid, green, velutine. Flowers zygomorphic; pedicels 1-2.8 mm long, velutine, trichomes hyaline; sepals $3.5-4 \times 1.5-2.5 \mathrm{~mm}$, elliptic to ovate, green, sparsely velutine; petals $3.5-4.5 \times 2.7-3.5 \mathrm{~mm}$, obovate, white; stamens unequal, filaments $1.5-4 \mathrm{~mm}$ long, anthers $0.7-1 \mathrm{~mm}$ long, white; ovary 1.5-1.7 $\times$ $1-1.2 \mathrm{~mm}$, velutine, style $2.5-3.2 \mathrm{~mm}$ long, curved, stigma capitate. Capsules $0.8-1.3 \times 0.7-1.2 \mathrm{~cm}$, globose, green, sparsely velutine, trichomes hyaline. Seeds 3.5-4 × 2.8-3.2 mm, testa scrobiculate, brown to dark brown, hilum C-shaped, embryotega semidorsal, aril slightly translucent, cream, thick.

Specimens examined: Iúna, Serra do Valentim, trilha do Sr. Aristides, 27.I.2012, fl., J.P.F. Zorzanelli et al. 328 (VIES); 27.III.2014, fl., J.P.F. Zorzanelli 969 (RB, VIES); 15.XII.2015, fl., J.P.F. Zorzanelli 1391 (RB, VIES); Floresta do Senhor Aristides, 31.III.2016, fr., J.P.F. Zorzanelli 1505 (RB, VIES).

Siderasis zorzanellii is endemic to Iúna (Espírito Santo, Fig. 20) (Pellegrini \& Faden 2017). It can be distinguished from the other species from the genus by its vining habit, distichouslyalternate leaves, leaves base asymmetric, velutine, inflorescences axillary and terminal, and petals white (Fig. 41-n). According to Pellegrini \& Faden (2017), S. zorzanellii is categorized as Critically Endangered (CR). It flowers from December to March and produces fruits in March.

8. Tinantia erecta (Jacq.) Fenzl, Index Seminum Adversaria 1849-50: [10]. 1851. Figs. 21; 22a

Herbs $60-80 \mathrm{~cm}$ tall, annual, terrestrial. Roots fibrous, without terminal tubers. Stems erect, branched, green, glabrous, monomorphic when flowering. Leaves spirally-alternate; sheaths 0.5-1.5 $\mathrm{cm}$ long, glabrous, margins setose, trichomes hyaline; pseudopetiole $0.4-0.8 \mathrm{~mm}$ long, puberulous, trichomes hyaline; blades 9.5-18.3 × 3-6 cm, elliptic to lanceolate, concolorous, green, adaxially pilose along the margins, abaxially sparsely pilose, trichomes hyaline, base symmetric, cuneate to round, apex acuminate. Inflorescence terminal, erect; peduncle 5-9.5 cm long, hispid with a mixture of glandular and eglandular trichomes, hyaline; cincinni 1-4, verticillate, 7-15-flowered; cincinnus bracts $1-3 \times 1.5-2 \mathrm{~cm}$, fused to the cincinnus peduncle, bracteose, obovate, green, densely hispid with a mixture of glandular and eglandular trichomes, hyaline; bracteoles $1.5-3 \times 0.8-2.3 \mathrm{~mm}$, deltoid, green, hispid with a mixture of glandular and eglandular trichomes, hyaline. Flowers zygomorphic; hook-trichomes absent; pedicels 0.5-2.8 cm long, puberulous, trichomes hyaline;

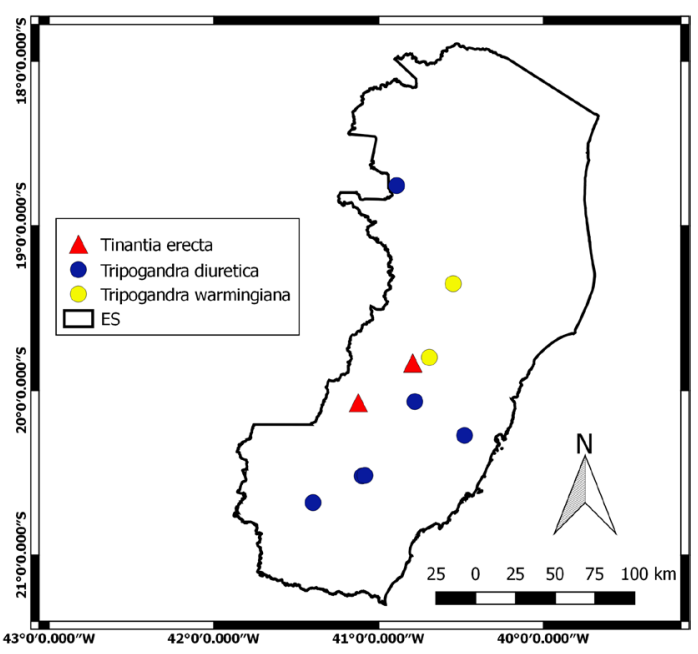

Figure 21 - Geographic distribution of Tinantia erecta, Tripogandra diuretica and Tripogandra warmingiana in the state of Espírito Santo. 
sepals 5-7 × 1.7-3 mm, elliptic, green, hispid with a mixture of glandular and eglandular trichomes, hyaline; petals 5-6.5 × 2.7-4 mm, unequal, cucullate, lilac to purple to bluish-purple; stamens 6 , dimorphic, the posteriors shorter than the anterior, filaments 3-4 mm long, filaments 3-4 mm long, barbate with moniliform trichomes, the posterior yellow, the anterior purple to bluish-purple, anthers $1.6-2 \times 0.5-1 \mathrm{~mm}$, rimose, the posterior yellow, the anterior purple to bluish-purple; staminodes absent; ovary $1.5-1.9 \times 0.8-1.3 \mathrm{~mm}$, hispid with a mixture of glandular and eglandular trichomes, hyaline, style 2.5-3 mm long, curved, stigma truncate. Capsules $0.8-1 \times 0.4-0.5 \mathrm{~cm}$, ellipsoid, thin-walled, hispid with a mixture of glandular and eglandular trichomes, hyaline, smooth, green when immature, brown when mature. Seeds 3-3.5 × 2-2.5 mm, testa rugose, brown, hilum C-shaped, embryotega lateral, concolorous with the testa.

Specimens examined: Afonso Claúdio, Vila pontões, estrada para garrafão, 27.I.2009, fl., A.P. Fontana \& L. Kollmann 5840 (MBML). Santa Teresa, Pedra da Paulista, 17.II.2000, fl., V. Demuner 730 (MBML). Venda Nova do Imigrante, Viaduto, BR-262, 9.I.1996, fl., G. Hatschbach \& J.M. Silva 48659 (CEPEC, MBM, US).

Tinantia erecta is widespread, ranging from Mexico to Argentina (Barreto 1997). In Brazil, it is recorded for the states of Distrito Federal, Goiás, Mato Grosso, Espírito Santo (Fig. 21), Minas Gerais, Rio de Janeiro, São Paulo, Paraná, and Santa Catarina (Aona et al. 2020). It is characterized by its verticillate cincinni, unequal petals, and filaments with moniliform trichomes of two colors. Tinantia erecta is categorized as Least Concern (LC) (CNCFlora 2012c). The information available in the herbaria indicates that it flowers from December to February.
9. Tradescantia L., Sp. Pl. 1: 288. 1753; emend M.Pell., PhytoKeys 89: 43. 2017.

Herbs perennial, terrestrial, rupicolous, or epiphytic. Roots fibrous, without terminal tubers. Stems erect or ascending, branched or not, monomorphic when flowering. Leaves spirally- or distichously-alternate, sessile or pseudopetiolate. Inflorescences terminal or axillary, exserted from the subtending leaf-sheath, sessile or pedunculate, erect; basal bract tubular and hyaline; cincinni 2, subopposite, fused back to back, sessile; cincinnus bracts leaf-like or spathaceous; bracteoles triangular, hyaline, glabrous. Flowers actinomorphic; hook-trichomes absent; sepals 3, equal or subequal, free or connate; petals 3 , equal, free or connate, white or pink; stamens 6 , arranged in two whorls, homomorphic or subequal, filaments free from the petals or epipetalous, bearded with moniliform trichomes, anthers rimose; ovary 3-locular, subglobose, glabrous, style straight, stigma punctate or capitate or trilobate. Capsules loculicidal, subglobose to globose or oblongoid, thin-walled. Seeds exarillate, testa costate, hilum linear, embryotega dorsal or semilateral, concolorous with the testa.

Tradescantia is the second largest genus in the family, with ca. 90 exclusively Neotropical species, divided into five subgenera (Pellegrini 2017a). In Brazil, 19 species are recognized, of which only T. subg. Austrotradescantia, T. subg. Campelia, and $T$. subg. Mandonia occur naturally (Pellegrini et al. 2015; Pellegrini 2017a). Tradescantia is characterized by its inflorescences composed of a double-cincinni fused back to back, with each cincinnus subtended by an expanded bract, actinomorphic flowers with six equal or subequal stamens, and a linear hilum (Pellegrini 2017a ).

\section{Key to the species of Tradescantia of the state of Espírito Santo}

1. Petals free, filaments free, bearded at base with long moniliform trichomes, anthers yellow, stigma punctate; embryotega dorsal

2. Stems glabrous; leaf-blades with round base, subpetiole up to $1 \mathrm{~mm}$ long; cincinnus bracts leaflike; pedicels green, petals plicate. 9.1. Tradescantia fluminensis

2'. Stems pubescent; leaf-blades with truncate to cuneate base, pseudopetiole more than $2 \mathrm{~mm}$ long; cincinnus bracts spathaceous; pedicels white, petals flat. 9.2. Tradescantia umbraculifera

1'. Petals connate at least at base, filaments epipetalous, bearded at mid-length with short moniliform trichomes, anthers white to cream, stigma trilobate or capitate; embryotega semilateral .....

3. Stems erect, unbranched; leaves spirally-alternate; inflorescences axillary, perforating the leafsheath; sepals accrescent, juicy, and atro-vinaceous to black in fruit; petals sessile, white, stigma capitate. 9.3. Tradescantia zanonia 
3'. Stems prostrate to ascending, branched; leaves distichously-alternate; inflorescences terminal, not perforating the leaf-sheath; sepals not accrescent, membranous, and hyaline to tan-colored in fruit; petals clawed, pink to purple, stigma trilobate. 9.4. Tradescantia zebrina

9.1. Tradescantia fluminensis Vell., Fl. Flumin. Icon. 3: t. 152. $1831 . \quad$ Figs. 19i; 22b-d; 23

Herbs $20-40 \mathrm{~cm}$ tall., terrestrial, rupicolous, or epiphytic. Stems branched, prostrate to ascending, green, glabrous. Leaves distichouslyalternate; sheaths $0.4-0.9 \mathrm{~cm}$ long, margins ciliate; subpetiolate ca. $1 \mathrm{~mm}$ long, puberulous, trichomes hyaline; blades 3-7 $\times 1.5-3 \mathrm{~cm}$, elliptic to lanceolate, concolorous, green, glabrous on both sides, base asymmetric, round, apex acuminate. Inflorescence terminal and axillary, not perforating the leaf-sheath, erect; cincinni 6-10-flowered; cincinnus bracts $1.5-4 \times 0.8-2 \mathrm{~cm}$, leaf-like, broadly ovate, sparsely puberulous. Flowers flat; pedicels $0.8-1.5 \mathrm{~cm}$ long, green, glabrous; sepals 5-7 $\times 1.5-2 \mathrm{~mm}$, elliptic, free, green, pilose along the keel, trichomes hyaline, not accrescent, membranous, tan-colored in fruit; petals 6-9 $\times$ 3-4 mm, obovate, plicate, free, white; stamens 6 , homomorphic, filaments 3-4.6 mm long, free from the petals, bearded at base with long moniliform trichomes, anthers $0.3-0.8 \mathrm{~mm}$ long, yellow; ovary $0.9-1.2 \times 0.4-0.6 \mathrm{~mm}$, glabrous, style $2.3-3.5 \mathrm{~mm}$ long, stigma punctate. Capsules 3.3-4.1 × 2.7-2.9 $\mathrm{cm}$, subglobose to globose, green when immature, light brown when mature, glabrous. Seeds 1.4-1.6 $\times 1.1-1.2 \mathrm{~mm}$, testa brown to greyish-brown, costate; embryotega dorsal.

Specimens examined: Alegre, Pedra da Carneira, 30.VIII.2008, fl., D.R. Couto 849 (MBML). Aracruz, Guaraná, près Ribeirão do Meio, 30.VI.1993, fl., M. Pignal H310 (BAH, P). Castelo, Vargem Alta, 2.IX.1948, fl., A.C. Brade 19416 (RB); Parque Estadual Forno Grande, 10.VII.2004, fl., L. Kollmann et al. 6843 (MBML); 7.XI.2004, fl., L. Kollmann et al. 7221 (MBML); 29.IV.2006, fl., L. Kollmann et al. 8970 (MBML); trilha para o Forninho, 15.X.2008, fl., R.C. Forzza 5334 (CEPEC, MBML, RB, UPCB ); trilha para o mirante, 16.XI.2017, f1., Q.S. Moraes 281 (VIES). Domingos Martins, between São Pedro de Urânia and Pedra Azul, 31.VII.1986, fl., T.B. Croat 61837 (MO, R). Marechal Floriano, 13.XII.2017, fl., Q.S. Moraes 277 (VIES). Santa Maria de Jequitibá, Pedra do Garrafão, 23.VIII.2015, fl., M.C. Almeida 121 (R).

Tradescantia fluminensis is recorded from Argentina and Brazil (states of Espírito Santo, Rio de Janeiro, Minas Gerais, São Paulo, Paraná, Santa Catarina and Rio Grande do Sul), Paraguay and Uruguay; in the Atlantic Forest, Cerrado,
Chaco, and Pampa domains (Pellegrini 2018). In Espírito Santo (Fig. 23), T. fluminensis is found in growing in rainforest remnants associated with inselbergs, mainly humid and shaded places. Habit prostrate to ascending, branched, filaments with long moniliform trichomes, anthers yellow and stigma punctate are the most important diagnostic morphological characters to recognize it (Figs. 19i; 22b-d). Pellegrini (2018) assess T. fluminensis as Least Concern (LC). Flowers were recorded throughout the June to November.

\subsection{Trasdecantia umbraculifera Hand.-Mazz,} Denkschr. Kaiserl. Akad. Wiss., Wien Math.Naturwiss. Kl. 79: 204. $1908 . \quad$ Figs. 22e-g; 23 Herbs 20-30 cm tall., terrestrial. Stems branched, prostrate to ascending, green, pubescent. Leaves distichously-alternate; sheaths $3.2-9.6 \mathrm{~mm}$ long, margins ciliate; pseudopetiole 2-3.1 mm long, pilose, trichomes hyaline; blades 5-9.5 × 1.8-2.4 $\mathrm{cm}$, elliptic, discolorous, adaxially dark green, abaxially light green, glabrous on both sides, base asymmetric, cuneate, apex acuminate. Inflorescence terminal, not perforating the leaf-sheath, erect; peduncle $0.5-4.3 \mathrm{~cm}$ long; cincinni 2-5-flowered; cincinnus bracts $0.5-1.5 \times 0.2-1 \mathrm{~cm}$, spathaceous, ovate, glabrous. Flowers flat; pedicels $0.5-1.2$ $\mathrm{mm}$ long, white, sparsely glandular-pubescent at apex, trichomes hyaline; sepals $5.2-8.1 \times 2-3.7$ $\mathrm{mm}$, elliptic, free, green, pilose at apex, trichomes hyaline, not accrescent, membranous, tan-colored in fruit; petals $0.7-1.2 \times 0.3-0.6 \mathrm{~cm}$, elliptic, flat, free, white; stamens 6 , homomorphic, filaments $4.7-6.8 \mathrm{~mm}$ long, yellow; ovary $1.2-2 \times 0.8-1.3$ $\mathrm{mm}$, style $4.5-6.2 \mathrm{~mm}$ long, stigma punctate. Capsules 2.5-3.8 $\times 2.1-2.7 \mathrm{~cm}$, subglobose to globose, green when immature, light brown when mature, glabrous. Seeds 1.6-1.9 $\times 1.2-1.5 \mathrm{~mm}$, testa grey to greyish-brown, costate; embryotega dorsal. Specimens examined: Divino de São Lourenço, trilha para Pedra Escorada, 15.XI.2017, fl., M. Nadruz et al. 3295 (RB).

Tradescantia umbraculifera is recorded from Argentina and Brazil (states of Espírito Santo (Fig. 23), Minas Gerais, Rio de Janeiro, São Paulo, Paraná, Santa Catarina, and Rio Grande do Sul) and Paraguay; in the Atlantic Forest, Cerrado, and Chaco domains (Pellegrini 2018). It was found 

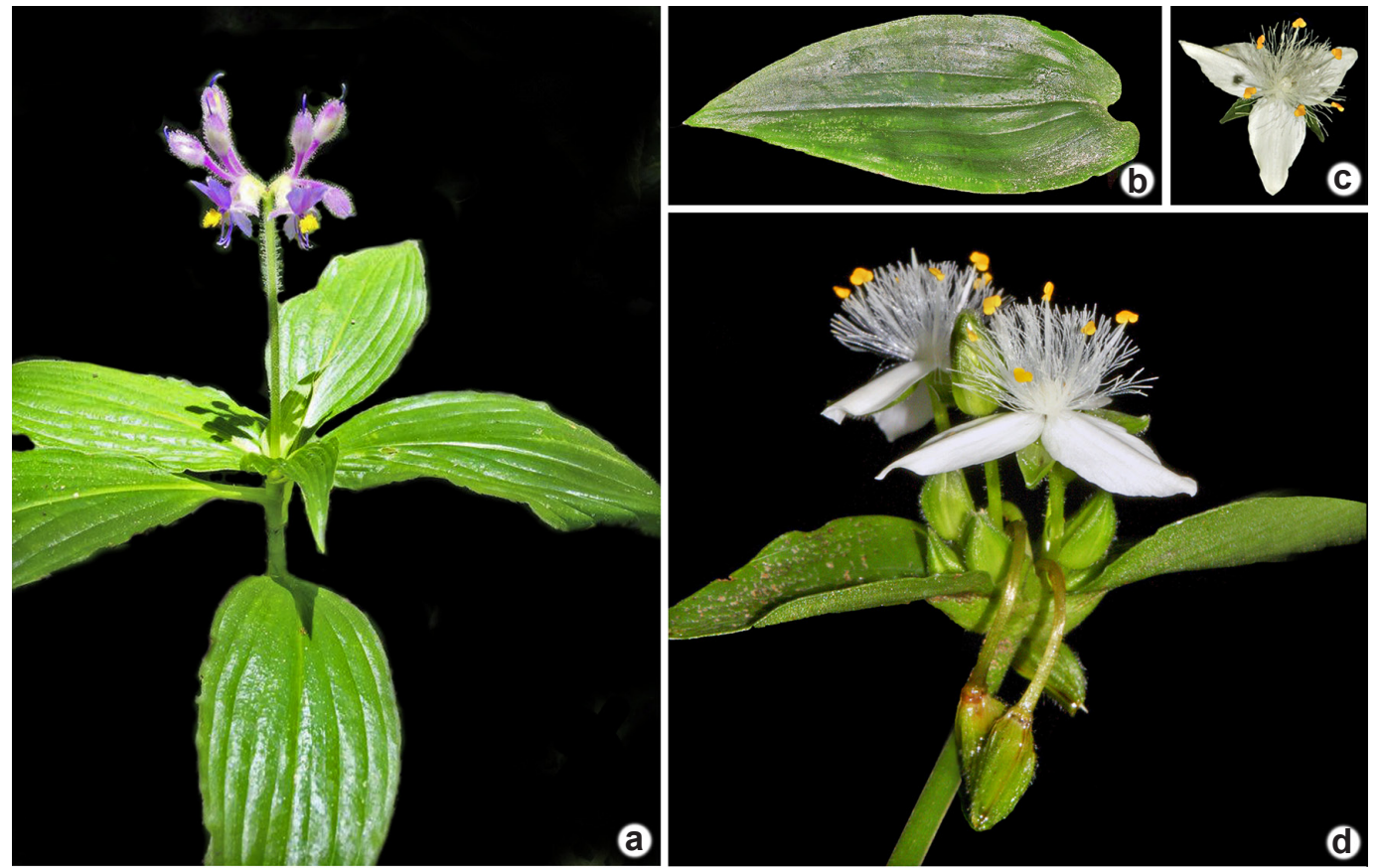

a
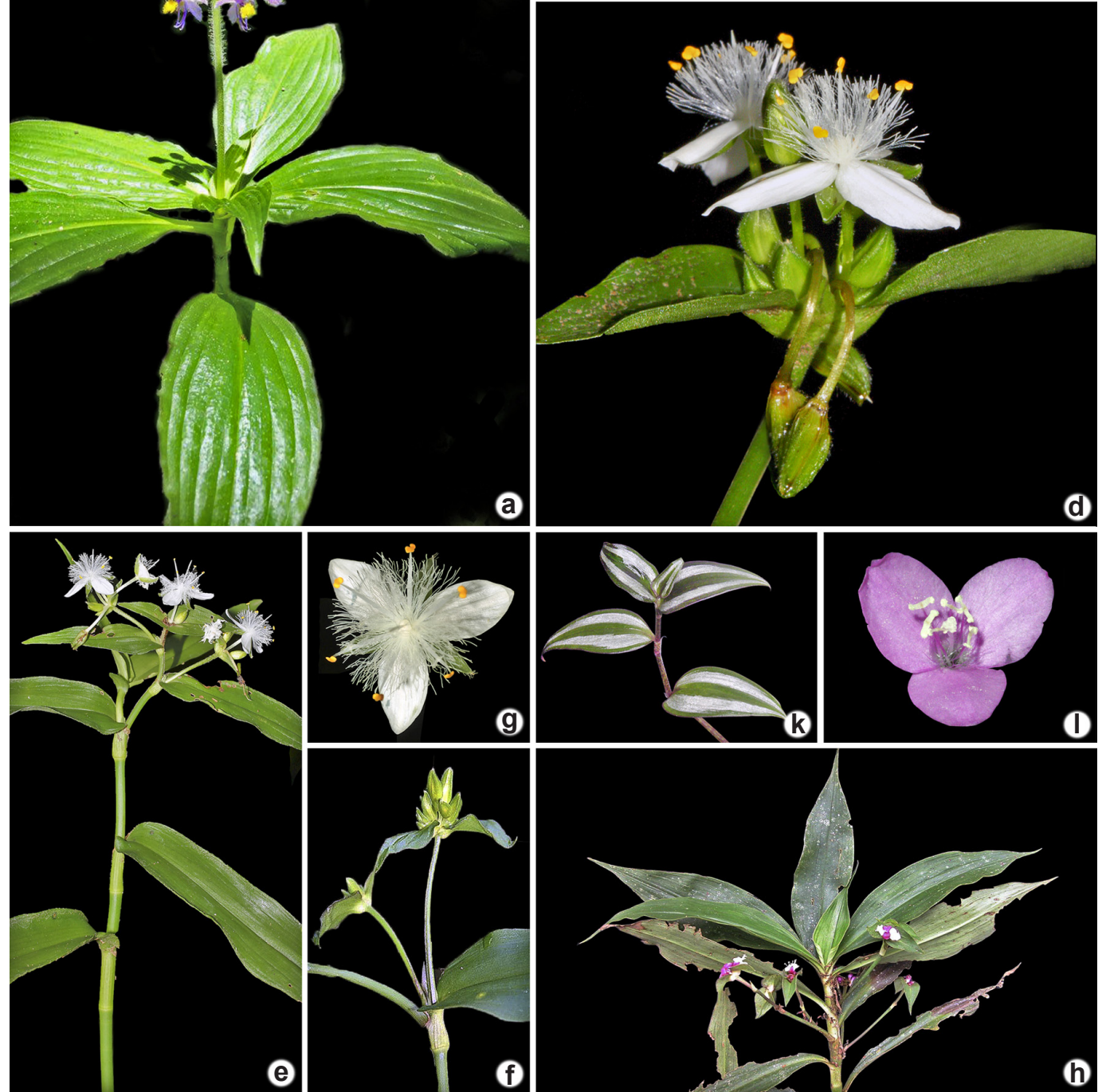

e
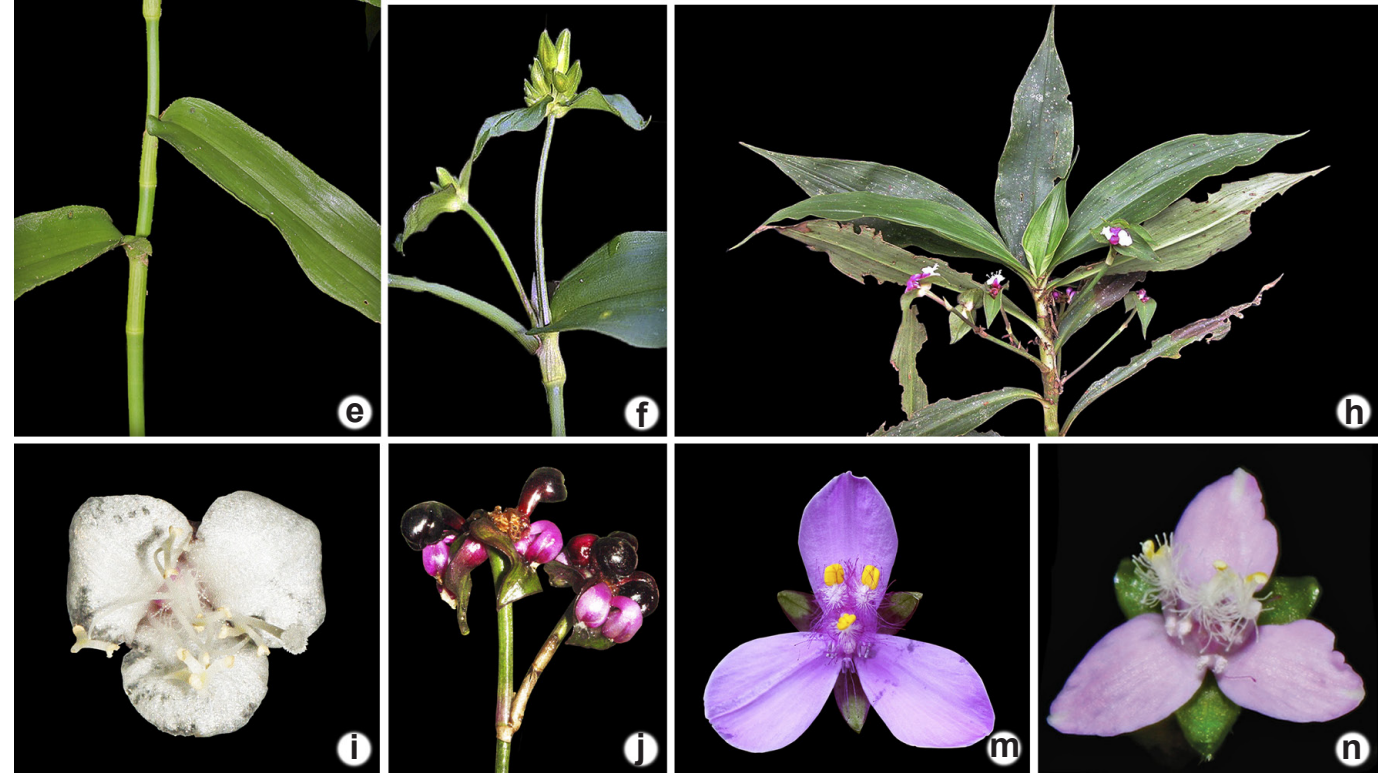

Figure 22 - a. Tinantia erecta - habit. b-d. Tradescantia fluminensis - b. adaxial side of the leaf-blade; c. front view of flower; d. detail of the inflorescence. e-g. Tradescantia umbraculifera - e. habit; f. detail of the inflorescence; g. front view of a flower. h-j. Tradescantia zanonia - h. habit; i. front view of flower; j. detail of the inflorescence. k-1. Tradescantia zebrina - k. habit; 1 . front view of a flower. $m$. Tripogandra diuretica - front view of flower; $\mathrm{n}$. Tripogandra warmingiana - front view of a flower. (Photos: a. MAN Coelho; b-c, f, i-n. MOO Pellegrini; e-g. H Medeiros; h. AP Macede). 
growing as a terrestrial understory in shaded and moist forests from altitudinal grasslands. It can be distinguished from $T$. fluminensis by its pubescent stems (vs. glabrous in T. fluminensis), pseudopetioles longer than $2 \mathrm{~mm}$ ( $v s$. up to $1 \mathrm{~mm}$ long), spathaceous cincinnus bracts (vs. leak-like), and petals flat (vs. plicate). Pellegrini (2018) assess T. umbraculifera as Least Concern (LC). It flowers in November.

9.3. Tradescantia zanonia (L.) Sw., Prodr. [O.P. Swartz] 57. 1788.

Figs. 22h-j; 23

Herbs $25-60 \mathrm{~cm}$ tall., terrestrial or rupicolous. Stems unbranched, erect, green, glabrous. Leaves spirally-alternate; sheaths $0.8-1.3 \mathrm{~cm}$ long, margins setose; pseudopetiole 3-6 mm long, pilose, trichomes hyaline; blades 5-9.5 × 2.5-4 $\mathrm{cm}$, elliptic to oblanceolate, concolorous, green, adaxially glabrous, abaxially strigose, trichomes hyaline, base symmetric, cuneate, apex acuminate. Inflorescence axillary, perforating the leafsheaths, erect; peduncle $3.5-7.1 \mathrm{~cm}$ long; cincinni 4-9-flowered; cincinnus bracts 1.3-4.5 × 1-2 cm, spathaceous, broadly ovate, sparsely strigose at base. Flowers tubular, tube broad; pedicels 2-5 $\mathrm{mm}$ long, green, glabrous; sepals 4-6 × 1.5-2.3 $\mathrm{mm}$, elliptic, connate, pink to purple, puberulous, trichomes hyaline, accrescent, juicy, and atrovinaceous to black in fruit; petals $5.6-8 \times 4-5.7$ $\mathrm{mm}$, obovate, sessile, connate at base, white; stamens 6, subequal, filaments 4-7 mm long, epipetalous, bearded at mid-length with short moniliform trichomes, anthers 1-1.6 mm long, cream to white; ovary $0.9-1.4 \times 0.7-1 \mathrm{~mm}$, style 5-8 mm long, stigma capitate. Capsules 5.8-7 $\times$ 4.5-5.7 mm, oblongoid, green when immature, light brown when mature, glabrous. Seeds $0.8-1 \times$ 1.5-1.7 mm, testa grey to greyish-brown, smooth; embryotega semilateral.

Specimens examined: Atílio Vivácqua, Moitão do Sul, serra das torres, 26.IV.2008, fl. and fr., A.P. Fontana et al. 3216 (MBML). Cariacica, Reserva Biológica de Duas Bocas, 21.VII.2008, fl., R.C. Forzza et al. 5273 (MBML, RB). Santa Leopoldina, Fazenda Caioabá, 16.IV.2013, fl., M.O.O. Pellegrini et al. 330 (VIES, RB); Colina Verde, Morro do Agudo, 29.V.2007, fl. and fr., V. Demuner et al. 4060 (MBML); propriedade dona Maria, 15.III.2007, fl., V. Demuner et al. 3211 (MBML). Santa Maria de Jetibá, Pedra do Garrafão, 21.IV.2003, fl. and fr., L. Kollmann et al. 6122 (MBML). Santa Teresa, Rio Saltinho, 29.V.2001, fl., L. Kollmann et al. 3719 (MBML); 4.IX.2001, fr., L. Kollmann et al. 4484 (MBML). Viana, São Paulo de Viana, 11.IV.2009, fr., L. Daneu et al. 18 (MBML, RB).
Tradescantia zanonia is the most widespread species of the genus, ranging from Mexico to Argentina (Pellegrini 2017a). In Espírito Santo (Fig. 23), it is recorded growing in rainforest remnants. It is easily recognized by its axillary inflorescences perforating the leaf-sheaths, and sepals that become juicy and atro-vinaceous to black in fruit (giving the impression the fruit is a berry). The species has not had its conservation assessed yet. Flowers and fruits were recorded from March to July and November.

9.4. Tradescantia zebrina Heynh. ex Bosse, Vollst. Handb. Bl.-gärtn., ed. 2 4: 655. 1849.

Figs. 19j; 22k-1; 23

Herbs 10-20 cm tall., rupicolous or terrestrial. Stems branched, prostrate to ascending, green, glabrous. Leaves distichously-alternate; sheaths 0.7-1.2 cm long, margins ciliate; pseudopetiole 1-2 mm long, margins ciliate, trichomes hyaline; blades $3-8 \times 1.5-3.5 \mathrm{~cm}$, elliptic to lanceolate to ovate, discolorous, adaxially green, with two longitudinal silver stripes, abaxially purple, sparsely puberulous on both surfaces, trichomes hyaline, base asymmetric, round, apex acute. Inflorescence terminal, not perforating the leafsheath, erect; peduncle 1-2 cm long; cincinni 2-4-flowered; cincinnus bracts $0.8-2 \times 0.7-1.3 \mathrm{~cm}$, spathaceous, broadly ovate, sparsely puberulous. Flowers tubular, tube narrow; pedicels $0.5-0.8 \mathrm{~cm}$ long, green, puberulous, trichomes hyaline; sepals 5-6 × 1.3-1.5 mm, oblong, connate, tan-colored

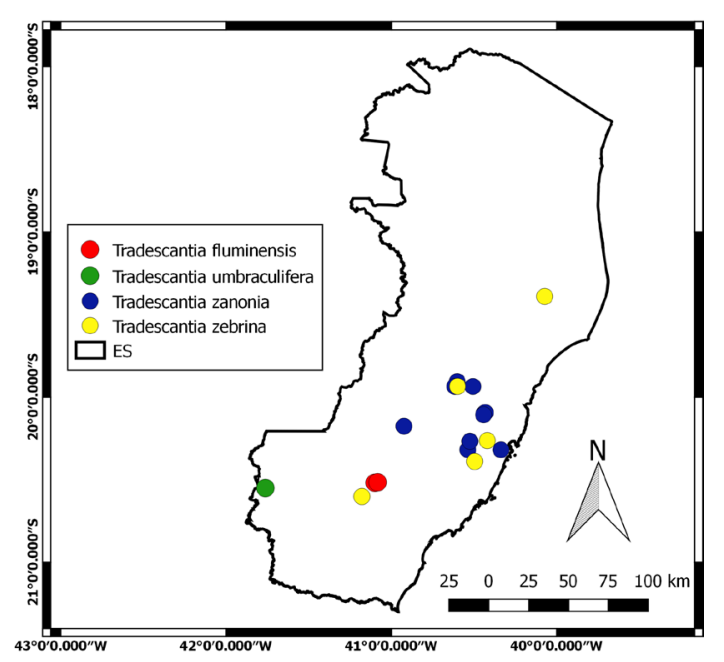

Figure 23 - Geographic distribution of Tradescantia fluminensis, T. umbraculifera, T. zanonia and T. zebrina in the state of Espírito Santo. 
to green, pilose along the keel, not accrescent, membranous, hyaline to tan-colored in fruit; petals 5-7 $\times 2-3.5 \mathrm{~mm}$, obovate, clawed, connate, pink to purple; stamens 6 , subequal, filaments $2-3 \mathrm{~mm}$ long, epipetalous, bearded at mid-length with short moniliform trichomes, anthers $0.7-1 \mathrm{~mm}$ long, white; ovary $0.8-1 \times 0.4-0.6 \mathrm{~mm}$, style $1.8-2.9$ $\mathrm{mm}$ long, stigma trilobate. Capsules not seen. Seeds not seen.

Specimens examined: Castelo, Parque Estadual de Mata das Flores, 2.II.2013, fl., T.T. Carrijo et al. 1636(VIES); 2.II.2013, fl., T.T. Carrijo et al. 1639 (VIES). Linhares, Reserva Natural Vale, 14.IV.1998, fl., D.A. Folli 3145 (CVRD, RB). Marechal Floriano, 22.IV.2008, fl., J.W. Calatrone 96 (VIES). Santa Teresa, Vale do Canaã, 8.V.1984, fl., W. Boone 116 (MBML); pátio do Museu de Biologia Mello Leitão, 25.VI.2001, fl., L. Kollmann 4002 (MBML); 22.I.2018, fl., Q.S. Moraes 312 (VIES). Viana, Bairro Jucu, fazenda do INCAPER, 8.VI.2010, fl., P.T. Neves 34 (MBML). Vitória, Praia do Canto, 24.I.1985, fl., B. Weinberg; et al 271 (MBML).

Tradescantia zebrina is a naturalized species, originally native to Mexico and Central America, but currently broadly distributed in South America (Pellegrini et al. 2015; Aona et al. 2020). It is widely recognized as an aggressive invasive, being commonly found in Espírito Santo in anthropized areas (Fig. 23). It is easily recognized by its leafblades discolorous (green with two longitudinal silver stripes adaxially, purple abaxially), narrowly tubular flowers, connate sepals, petals pink to purple, and epipetalous stamens. Tradescantia zebrina has not had its conservation assessed yet. Flowers were recorded from January to June.

10. Tripogandra Raf., Fl. Tellur. 2: 16. 1837.
Herbs perennial or annual, terrestrial, rupicolous, paludal or aquatic. Roots fibrous, without terminal tubers. Stems erect or decumbent, branched, monomorphic when flowering. Leaves distichously-alternate, sessile or pseudopetiolate. Inflorescences terminal, pedunculate, exserted from the subtending leaf-sheath, erect; basal bract tubular and hyaline; cincinni 2, subopposite, fused back to back, sessile; cincinnus bracts vestigial (a hyaline crest); bracteoles triangular, hyaline, glabrous. Flowers zygomorphic with a $60^{\circ}$ torsion in the floral display; hook-trichomes absent; sepals 3, equal; petals 3, equal, white to pale pink to pink to lilac; stamens 6 , sometimes 3 staminodial, dimorphic, filaments sigmoid, the opposite sepals shorter and pointing downwards, glabrous, the opposite petals longer and pointing upwards, bearded at apex with long moniliform trichomes, anthers rimose; ovary 3-locular, globose, style straight, stigma capitate. Capsule loculicidal, subglobose to globose, thin-walled. Seeds exarillate, triangular, testa reticulate or areolate-reticulate, gray; hilum punctiform; embryotega dorsal, concolorous with the testa.

Tripogandra is a Neotropical genus, with ca. 22 species (Handlos 1975; Pellegrini 2017a), of which seven species are listed from Brazil (Pellegrini et al. 2013; Aona et al. 2020). It is morphologically similar to Tradescantia, being easily distinguished by its vestigial cincinnus bracts, zygomorphic flowers with a $60^{\circ}$ torsion in the floral display, and dimorphic stamens (three opposite to the sepals and pointing downward and three opposite to the petals pointing upwards) (Handlos 1975; Pellegrini 2017a).

\section{Key to the species of Tripogandra of the state of Espírito Santo}

1. Stems erect; petals ovate to obovate, filaments with non-moniliform trichomes; seeds areolatereticulate. 10.1. Tripogandra diuretica

1'. Stems decumbent; petals elliptic to ovate, filaments with moniliform trichomes; seeds reticulate......... 10.2. Tripogandra warmingiana

10.1. Tripogandra diuretica (Mart.) Handlos, Rhodora 77: 259. $1975 . \quad$ Figs. 19k-n; 21;22m

Herbs $40-60 \mathrm{~cm}$ tall., terrestrial, paludal or aquatic. Stems erect, glabrescent, trichomes hyaline. Leaf-sheaths $6-9 \mathrm{~mm}$ long, pubescent, margins ciliate; sessile; blades 4.5-10 × 1.0-2.5 $\mathrm{cm}$, elliptic to lanceolate, concolorous, green, adaxially glabrescent, abaxially sparsely pubescent, base asymmetric, cuneate, apex acuminate. Inflorescence with peduncle $3-5 \mathrm{~cm}$ long; cincinni 2-9-flowered; bracteoles 1.5-2 mm long. Flowers with pedicels $2-9 \mathrm{~mm}$ long, glabrous; sepals $3-5$ $\times 2-3 \mathrm{~mm}$, elliptic to obovate, green, glabrous; petals 4-7 × 3-4 mm, ovate to obovate, white to pale pink to pink to lilac; stamens 3, opposite sepals, filaments $1-1.5 \mathrm{~mm}$ long, anthers $0.8-1 \times$ 
0.8-1.2 mm, white to pale pink to pink to lilac; staminodes 3 , opposite petals, filaments $3-4 \mathrm{~mm}$ long, trichomes non-moniliform, white to pale pink to pink to lilac, antherodes $0.5-0.7 \times 0.2-0.4 \mathrm{~mm}$, yellow; ovary $1-1.2 \times 0.4-0.6 \mathrm{~mm}$, style $0.8-1.5$ $\mathrm{mm}$ long. Capsules 3-4 × 1-2 mm. Seeds $1-1.2 \times$ 0.5-0.7 mm, testa areolate-reticulate.

Specimens examined: Alegre, Monte Cristo, 20.I.2008, fl., L. Kollmann et al.10376 (MBML). Barra de São Francisco, Parque Municipal Sombra da Tarde, 12.XII.2000, fl., L. Kollmann et al. 3511 (MBML). Cariacica, Reserva Biológica de Duas Bocas, 9.I.2007, fl., L. Kollmann 9443 (MBML). Castelo, Parque Estadual Forno Grande, mata de brejo próxima da sede, 8.IV.2009, fl., R.C. Forzza 5488 (RB); trilha para o mirante, 23.I.2013, fl., J.A. Oliveira 285 (RB); Parque Estadual Mata das Flores, 6.IV.2017, fl., T.T. Carrijo 2268(VIES); 4.IV.2017, fl., T.T. Carrijo 2272 (VIES). Santa Maria de Jetibá, terreno de R. Berger, 3.IV.2003, fl., L. Kollmann et al. 6087 (MBML).

Tripogandra diuretica is recorded from Argentina, Brazil, México, Guatemala, Panamá, Paraguay, Peru and Uruguay (Handlos 1975). It is recorded for all regions in Brazil but considerably rare in the Northern region (Aona et al. 2020). In Espírito Santo (Fig. 21), it is generally found growing in very humid places. There is a considerable variation in petal shape (ovate to obovate) and coloration (white to pale pink to pink to lilac). Nonetheless, the non-moniliform trichomes in the filaments and areolate-reticulate seeds these characters are diagnostic for specie delimitation. Tripogandra diuretica has not had its conservation assessed yet. Flowering was recorded from December to April.

10.2. Tripogandra warmingiana (Seub.) Handlos, Rhodora 77: 311. 1975. Figs. 19o-p; 21; 22n

Herbs 10-20 cm tall., rupicolous or terrestrial. Stems decumbent, glabrescent, trichomes hyaline. Leaf-sheaths 2-5 mm long, light green, margins ciliate; pseudopetiole $0.5-2 \mathrm{~mm}$ long, glabrous; blades $2-5 \times 1-1.5 \mathrm{~cm}$, elliptic to obovate, concolorous, green, glabrous on both sides, base asymmetric, round, apex acute to acuminate. Inflorescence with peduncles $0.4-1 \mathrm{~cm}$ long; cincinni 1-3-flowered; bracteoles 0.5-1 mm long. Flowers with pedicel 4-7 mm long, sparsely pilose near the apex; sepals $2-4 \times 1.3-1.5 \mathrm{~mm}$, ovate, green, sparsely pilose along the midvein; petals 4-5 $\times 2-3 \mathrm{~mm}$, elliptic to ovate, pale pink to pink to lilac; stamens 6 , the opposite sepals with filaments 0.8-1 mm long, anthers 0.4-0.6 × 0.3-0.5 mm, pale pink to pink to lilac, the opposite petals with filaments 2.8-3.5 mm long, trichomes moniliform, pale pink to pink to lilac, anthers $0.2-0.3 \times 0.8-1$ $\mathrm{mm}$, yellow; ovary $0.8-1 \times 0.7-0.8 \mathrm{~mm}$, style 0.4-0.6 mm long. Capsules 2.2-2.7 × 2-2.5 mm. Seeds $1.2-1.8 \times 1.2 \mathrm{~mm}$, testa reticulate.

Specimens examined: Marilândia, Alto Liberdade, Pedra do Cruzeiro, 20.IV.2013, fl., M.O.O. Pellegrini 346 (RB). Santa Teresa, São João de Petrópolis, Valão de São Brás, 6.II.2013, fl., V.B. Sarnaglia Jr. 643 (RB). Viana, Jucuruaba, fazenda experimental Reginaldo Conde, INCAPER, 1.II.2016, fl., M. Ribeiro 1222 (RB).

Tripogandra warmingiana is endemic to Brazil, recorded for the states of Bahia, Espírito Santo (Fig. 21), Minas Gerais, and Rio de Janeiro (Pellegrini et al. 2013; Aona et al. 2020). It occurs in the understory of evergreen and semideciduous forests and other moist, shaded habitats in the Atlantic Forest (Pellegrini et al. 2013). It can be recognized by its minute habit $(10-20 \mathrm{~cm}$ tall), decumbent stems, petals elliptic to ovate, stamens opposite petals bearded with moniliform trichomes, and seeds reticulate. The species is categorized as Vulnerable (VU) (CNCFlora 2012d). The information available in the herbaria indicate flowering from February to April.

\section{Acknowledgments}

The authors would like to thank the curators of the visited herbaria, for assisting our studies; the staff of the conservation units collected (ICMBIO, VALE, IEMA); and UFES for logistical support. QSM thanks the CAPES (Coordenação de Aperfeiçoamento de Pessoal de Nível Superior \#001), for granting graduate scholarship. AAA thanks FAPES, for a research grant ("Capixaba Researcher Fellowship" \#525/2018). We would also like to thank Renara Nichio Amaral and Joelcio Freitas, for their assistance during fieldwork and preparing the line drawings.

\section{References}

Aona LYS (2008) Revisão taxonômica e análise cladística do gênero Dichorisandra J.C.Mikan (Commelinaceae). Ph.D. thesis. Universidade Estadual de Campinas, Campinas. 310p.

Aona LYS, Faden RB \& Amaral MCE (2012) Five new species of Dichorisandra J.C. Mikan (Commelinaceae) from Bahia state, Brazil. Kew Bulletin 66: 1-13.

Aona LYS, Bittrich V \& Amaral MCE (2014) Two new species of Dichorisandra (Commelinaceae) from Rio de Janeiro and comments on the two species included in Vellozo's Flora Fluminensis. Phytotaxa 184: 223-234. 
Aona LYS, Costa GM \& Amaral MCE (2016a) Flora rupestre das cangas da Serra dos Carajás: Commelinaceae. Rodriguésia 67: 1291-1300.

Aona LYS, Bittrich V \& Amaral MCE (2016b) Taxonomic novelties in Brazilian Dichorisandra (Commelinaceae): D. sagittata $\mathrm{sp}$. nov. and $D$. glabrescens stat. nov. Brittonia 68: 1-9.

Aona LYS, Faden RB, Amaral MCE \& Bittrich V (2016c) Four new species of Dichorisandra (Commelinaceae) endemic from Bahia state, Brazil. Brittonia 68: 61-73.

Aona LYSP \& Pellegrini MOO (2014) Commelinaceae. In: Kaehler M, Goldenberg R, Labiak PH, Ribas OS, Vieira AOS \& Hatschbach GG (ed.s) Plantas vasculares do Paraná. Vol. 1. Universidade Federal do Paraná.

Aona LYS, Pellegrini MOO \& Amaral MCE (2020) Commelinaceae in Flora do Brasil 2020. Instituto de Pesquisas Jardim Botânico do Rio de Janeiro. Available at $<$ http://floradobrasil.jbrj.gov.br/reflora/ floradobrasil/FB91>. Access on 2 March 2021.

Aona-Pinheiro LYS \& Amaral MCE (2012) Four new species of Dichorisandra J.C. Mikan (Commelinaceae) from Southeast Brazil. Phytotaxa 48: 7-22.

Barreto RC (1997) Levantamento das espécies de Commelinaceae R.Br. nativas do Brasil. Ph.D. thesis. Universidade de São Paulo, São Paulo. 490p.

Barreto RC (2005) Commelinaceae. In: Wanderley MGL, Shepherd GJ, Melhem TS, Martins SE, Kirizawa M \& Giulietti AM (eds.) Flora fanerogâmica do estado de São Paulo. Instituto de Botânica, São Paulo. Vol. 4, pp. 195-210.

Beentje HJ \& Lansdown RV (2018) Commelina benghalensis. The IUCN Red List of Threatened Species 2018: e.T177240A120145118. Available at $<$ https://dx.doi.org/10.2305/IUCN.UK.2018-2. RLTS.T177240A120145118.en>. Access on 13 June 2021.

Bosse J (1849) Tradescantia zebrina hort. ex Bosse. Vollständiges Handbuch der Blumengärtnerei 4: 655.

Brade AC (1957) Espécies novas da Flora do Brasil II. Arquivos do Jardim Botânico do Rio de Janeiro XV: 5-20.

Chodat RH \& Hassler É (1901) Commelina villosa C.B.Clarke ex Chodat \& Hassl. Bulletin de l'Herbier Boissier, sér. 2, 1: 438.

Clarke CB (1881) Dichorisandra perforans C.B.Clarke. Monographiae Phanerogamarum 3: 281.

CNCFlora (2012a) Dichorisandra acaulis in Lista Vermelha da flora brasileira versão 2012.2. Centro Nacional de Conservação da Flora. Available at $<$ http://cncflora.jbrj.gov.br/portal/pt-br/profile/ Dichorisandra acaulis $>$. Access on 22 December 2018.

CNCFlora (2012b) Dichorisandra neglecta in Lista Vermelha da flora brasileira versão 2012.2. Centro Nacional de Conservação da Flora. Available at
$<$ http://cncflora.jbrj.gov.br/portal/pt-br/profile/ Dichorisandra neglecta $>$. Access on 22 December 2018.

CNCFlora (2012c) Tinantia erecta in Lista Vermelha da flora brasileira versão 2012.2. Centro Nacional de Conservação da Flora. Available at $<$ http://cncflora. jbrj.gov.br/portal/pt-br/profile/Tinantia erecta $>$. Access on 22 December 2018.

CNCFlora (2012d) Tripogandra warmingiana in Lista Vermelha da flora brasileira versão 2012.2. Centro Nacional de Conservação da Flora. Available at $<$ http://cncflora.jbrj.gov.br/portal/pt-br/profile/ Tripogandra warmingiana $>$. Access on 22 December 2018.

CRIA(2018) SpeciesLink Ferramenta desenvolvida pelo CRIA. Available at $<$ http://www.splink.org.br $>$. Access on 28 November 2018.

Dutra VF, Alves-Araújo A \& Carrijo TT (2015) Angiosperm checklist of Espírito Santo: using electronic tools to improve the knowledge of an Atlantic Forest biodiversity hotspot. Rodriguésia 66: 1145-1152.

Evans TM, Sytsma KJ, Faden RB \& Givnish TJ (2003) Phylogenetic relationships in the Commelinaceae: II. A cladistic analysis of $r b c L$ sequences and morphology. Systematic Botany 28: 270-292.

Faden RB \& Hunt DR (1991) The classification of the Commelinaceae. Taxon 40: 19-31.

Faden RB (1991) The morphology and taxonomy of Aneilema R. Brown (Commelinaceae). Smithsonian Contributions to Botany. Vol. 76. Smithsonian Institution Press, Washington, D.C. 187p.

Faden RB (1998) Commelinaceae. In: Kubitzki K (ed.) The families and genera of vascular plants. Vol. 4. Springer Verlag, Berlin. Pp. 109-128. <https://doi. org/10.1007/978-3-662-03531-3_12>

Garbin ML, Saiter FZ, Carrijo TT \& Peixoto AL (2017) Breve histórico e classificação da vegetação capixaba. Rodriguésia 68: 1883-1894.

GBIF (2018) Global Biodiversity Information Facility. Available at $<\mathrm{http}$ ://www.gbif.org $>$. Access on 28 November 2018.

Ghogue JP \& Kumar B (2020) Commelina erecta. The IUCN Red List of Threatened Species 2020: e.T176972A140389177. Available at <https:// dx.doi.org/10.2305/IUCN.UK.2020-2.RLTS. T176972A140389177.en>. Access on 13 June 2021.

Govaerts R \& Faden RB (2011) World checklist of Commelinaceae. The board of trustees of the Royal Botanic Gardens, Kew. Available on $<$ http://apps. kew.org/wcsp/home.do $>$. Access on 28 November 2018.

Handlos WL (1975) The taxonomy of Tripogandra. Rhodora 77: 213-333.

Hardy CR \& Faden RB (2004) Commelinaceae. In: Smith N, Mori SA, Henderson A, Stevenson DW \& Held SV (eds.) Flowering plants of the neotropics. Princeton University Press, Princeton. Pp. 425-427. 
Harris JG \& Harris MW (2001) Plant identification terminology: an illustrated glossary. 2nd ed. Spring Lake Pub, Utah. 206p.

Hijmans RJ, Guarino L \& Mathur P (2012) DIVA-GIS. Version 7.5.0. A geographic information system for the analysis of species distribution data. Available at $<$ http://www.diva-gis.org $>$. Access on 8 January 2019.

Hunt DR (1975) Tradescantia pallida ( Rose ) DRHunt. Kew Bulletin 30: 453.

Hunt DR (1979) Tripogandra elata D.R.Hunt. Kew Bulletin 33: 405.

Hunt DR (1986a) Amplification of Callisia Loefl. American Commelinaceae. XV. Kew Bulletin 41: 407-412.

Hunt DR (1986b) A revision of Gibasis Raf. American Commelinaceae. XII. Kew Bulletin 41: 107-129.

IBGE - Instituto Brasileiro de Geografia e Estatística (2017) Divisão Regional do Brasil em Regiões Geográficas Imediatas e Regiões Geográficas Intermediárias 2017. IBGE, Coordenação de Geografia, Rio de Janeiro. 82p.

IUCN (2012) IUCN red list categories and criteria version 3.1, 2nd edition. IUCN, Gland. 32p.

Kunth CS (1843) Dichorisandra penduliflora Kunth. Enumeratio Plantarum Omnium Hucusque Cognitarum 4: 114.

Lansdown RV (2018) Commelina diffusa. The IUCN Red List of Threatened Species 2018: e.T177028A67776407. Available at $<$ https:// dx.doi.org/10.2305/iucn.uk.2018-2.rlts. t177028a67776407.en>. Access on 13 June 2021.

Linnaeus C (1753) Commelina benghalensis L. Species Plantarum 1: 41.

Luber J, Tuler AC, Leite FT, Christ JA, Guidoni-Martins KG, Zanetti M, Holunder RK, Manhães VC, Zorzanelli JPF, Mendonça ES, Garbin ML \& Carrijo TT (2016) List of angiosperm species in an Atlantic Forest fragment reveals collection gaps in the state of Espírito Santo, Brazil. Check List 12: 1835.

Maia DC (2006) Estudo taxonômico dos gêneros Commelina L. e Dichorisandra J.C. Mikan (Commelinaceae), no estado do Paraná, Brasil. MSc. thesis. Universidade Federal do Paraná, Curitiba. 114p.

Mikan JC (1820) Dichorisandra thyrsiflora J.C.Mikan. Delectus Florae et Faunae Brasiliensis, t. 3. Sumtibus Auctoris, Typis Antonii Strauss, Viena. $23 \mathrm{p}$.

MMA - Ministério do Meio Ambiente (2014) Portaria $\mathrm{n}^{\mathrm{o}}$ 443, de 17 de dezembro de 2014. Reconhece como espécies da flora brasileira ameaçadas de extinção aquelas constantes da "Lista Nacional Oficial de Espécies da Flora Ameaçadas de Extinção". Available at <http://sintse.tse.jus.br/ documentos/2014/Dez/18/portaria-no-443-de-17de-dezembro-de-2014>. Access on 19 February 2018.
Moore HE (1956) Siderasis fuscata (Lodd.) H.E.Moore. Baileya 4: 28 .

Moraes QS, Pellegrini MOO \& Alves-Araújo A (2019) New Species of Dichorisandra (Commelinaceae) with Speckled Leaves from Brazil. Systematic Botany 44: 783-789.

Moraes QS, Pellegrini MOO \& Alves-Araujo A (2020) Dichorisandra forzzae sp. nov. (Commelinaceae) from the state of Espírito Santo, Brazil, with notes on the Dichorisandra acaulis group. Nordic Journal of Botany 38: 1-10.

Mori SA, Berkov A, Gracie CA \& Hecklau EF (2011) Tropical plant collecting. From the Field to the Internet. TECC Editora, Florianópolis. 332p.

Murray-Smith C, Brummitt NA, Oliveira-Filho AT, Bachman S, Moat J, Lughadha EMN \& Lucas EJ (2008) Plant diversity hotspots in the Atlantic Coastal Forests of Brazil. Conservation Biology 23: 151-163. DOI: 10.1111/j.1523-1739.2008.01075.x

Panigo E, Ramos J, Lucero L, Perreta M \& Vegetti A (2011) The inflorescence in Commelinaceae. Flora 206: 294-299.

Pellegrini MOO \& Almeida RF (2016) Rediscovery, identity and typification of Dichorisandra picta (Commelinaceae) and comments on the shortstemmed Dichorisandra species. Phytotaxa 245: 107-118. DOI: 10.11646/phytotaxa.245.2.2

Pellegrini MOO \& Faden RB (2017) Recircumscription and taxonomic revision of Siderasis, with comments on the systematics of subtribe Dichorisandrinae (Commelinaceae). PhytoKeys 83: 1-41.

Pellegrini MOO \& Forzza RC (2017) Synopsis of Commelina L. (Commelinaceae) in the state of Rio de Janeiro, reveals a new white-flowered species endemic to Brazil. PhytoKeys 78: 59-81.

Pellegrini MOO (2016) A new species of Tradescantia L. sect. Austrotradescantia D.R.Hunt (Commelinaceae) from Southern Brazil. Phytotaxa: a rapid international journal for accelerating the publication of botanical taxonomy 265: 79-84.

Pellegrini MOO (2017a) Siderasis albofasciata sp. nov. (Commelinaceae), endemic to the state of Espírito Santo, Brazil, and the typification of S. fuscata. Nordic Journal of Botany 35: 29-37. <https://doi. org/10.1111/njb.01267>.

Pellegrini MOO (2017b) Morphological phylogeny of Tradescantia L. (Commelinaceae) sheds light on a new infrageneric classification for the genus and novelties on the systematics of subtribe Tradescantiinae. PhytoKeys 89: 11-72.

Pellegrini MOO (2018) Wandering throughout South America: Taxonomic revision of Tradescantia subg. Austrotradescantia (D.R.Hunt) M.Pell. (Commelinaceae). PhytoKeys 104: 1-97. DOI: https://doi.org/10.3897/phytokeys.104.28484

Pellegrini MOO, Aona-Pinheiro LYS \& Forzza RC (2013) Taxonomy and conservation status of Tripogandra warmingiana (Seub.) Handlos 
(Commelinaceae), a previously obscure taxon from Brazil. Phytotaxa 91: 39-49. <https://doi. org/10.11646/phytotaxa.91.2.2>.

Pellegrini MOO, Faden RB \& Almeida RF (2016) Taxonomic revision of Neotropical Murdannia Royle (Commelinaceae). PhytoKeys 74: 35-78.

Pellegrini MOO, Forzza RC \& Sakuragui CM (2015) A nomenclatural and taxonomic review of Tradescantia (Commelinaceae) species described in Vellozo's Flora fluminensis with notes on Brazilian Tradescantia. Taxon 64: 151-155.

Pellegrini MOO, Forzza RC \& Sakuragui CM (2017) Novelties in Brazilian Tradescantia L. (Commelinaceae). PhytoKeys 80: 1-31.

Pellegrini, MOO; Cornejo, X; Michelan, TS (in press) Taxonomic novelties in the gem-fruited group of Commelina L. (Commelinaceae). Kew Bulletin.

Radford AE, Dickison WC, Massey JR \& Bell CR (1974) Vascular plant systematics. Harper \& Row, New York. 891p.

Schultes F (1830) Dichorisandra procera Mart. ex Schult. f. Systema Vegetabilium 7: 1187-1188.

Spjut RW (1994) A systematic treatment of fruit types. The New York Botanical Garden, New York. 181p.
Swartz O (1788) Tradescantia spathacea Sw. Nova Genera et Species Plantarum seu Prodromus 57: 57.

Taubert PHW (1890) Dichorisandra glaziovii Taub. Botanische Jahrbücher für Systematik, Pflanzengeschichte und Pflanzengeographie 12: 2.

Thiers B [continuously updated] Index Herbariorum: a global directory of public herbaria and associated staff. New York Botanical Garden's Virtual Herbarium. Available at $<$ http://sweetgum.nybg. org/science/ih/>. Access on 28 November 2018.

Tseng YH, Chao CT, Wang CC \& Liu SC (2010) Callisia repens (Jacq.) L. (Commelinaceae), a Newly Naturalized Plant in Taiwan. Quarterly Journal of Forest Research 32: 1-6.

Weberling F (1965) Typology of inflorescences. Botanical Journal of the Linnean Society 59: 15-221.

Weberling F (1989) Morphology of flowers and inflorescences. Cambridge University Press, Cambridge. 432p.

Werneck MS, Sobral MEG, Rocha CTV, Landau EC \& Stehmann JR (2011) Distribution and endemism of angiosperms in the Atlantic Forest. Natureza \& Conservação 9: 188-193. DOI: 10.4322/ natcon.2011.024 


\section{Specimen list}

Albuquerque AFM MBML 1228 (2). Alves-Araújo A 1806 (4.14), 1809 (4.14), 1824 (4.14), 1867 (4.14). Amaral MDC 44 (4.15). Amorim AM 7399 (3.1). Aona LYS 975 (4.15), 1491 (4.8). Assis AM 1511 (4.13), 1527 (4.13), 1727 (3.1), 2273 (4.13), 2411 (1), 2503 (4.13), 3159 (4.11). Boone W 116 (9.3), 695 (3.4), 833 (3.2), 968 (4.14), 1003 (3.4), 1071 (4.2), 1349 (7.1). Botelho RM 56 (3.1). Boudet Fernandes HQ 1201 (3.4), 1839 (4.1), 1864 (4.2), 1877 (4.2), 2662 (3.1), 2920 (4.11), 3332 (3.1), 3335 (3.1), 3349 (3.1). Brade AC 19416 (9.1), 20561 (4.7). Britto RC 152 (1), 154 (4.1). Broggio IS 196b (5). Calatrone JW 96 (9.3). Cardoso WC 262 (4.11). Carrijo TT 1636 (9.3), 1639 (9.3), 2263 (4.12), 2268 (10.1), 2272 (10.1). Chamas CC MBML 45109 (4.11). Couto DR 448 (4.14), 849 (9.1). Dal col ACS 64 (3.3), 318 (3.3), 436 (3.3). Daneu L 18 (9.2). Demuner V 730 (8), 1019 (6), 1800 (4.11), 3024 (4.6), 3118 (7.2), 3211 (9.2), 3360 (4.2), 3429 (7.2), 4060 (9.2), 4452 (4.4), 4682 (7.2), 4827 (3.3). Farias GL 484 (4.15), 485 (4.15), 615 (3.5), 1943 (3.4). Fiaschi P 3497 (4.15). Folli DA 1127 (4.15), 1767 (3.3), 1777 (6), 1787 (3.2), 2173 (4.1), 2739 (3.3), 2970 (4.15), 3145 (9.3), 3395 (3.4), 3637 (3.5), 5273 (9.2), 5997 (4.9). Fontana AP 494 (4.1), 758 (6), 1346 (6), 1778 (4.1), 2827 (7.1), 2975 (7.1), 3046 (4.1), 3216 (9.2), 5192 (4.5), 5778 (3.3), 5785 (4.13), 5840 (8). Forzza RC 4995 (4.5), 5114 (4.9), 5334 (9.1), 5488 (10.1), 5507 (3.1), 5514 (4.4), 8768 (4.14), 8782 (4.14). Fraga CN 2517 (4.13), 2531 (1). Freitas J 442 (3.5), 366 (4.11). Giaretta AO 14 (4.10). Gomes JML 113 (3.3), 617 (3.1), 2085 (3.3), 2291 (3.3). Gurtler J 5 (4.14), 57 (4.14), 68 (4.14), 85 (4.14). Hoffmann WA 128 (3.2). Iglesias DT 101 (3.3). Jesus MCF 364 (3.3). Kollmann L 1198 (3.3), 1656 (1), 3274 (4.9), 3336 (4.9), 3351 (4.9), 3511 (10.1), 3719 (9.2), 3724 (6), 4002 (9.3), 4450 (1), 4451 (6), 4484 (9.2), 5363 (4.1), 5571 (4.1), 6087 (10.1), 6121 (6), 6122 (9.2), 6740 (3.4), 6822 (6), 6843 (9.1), 7221 (9.1), 7604 (4.5), 8603 (1), 8970 (9.1), 9443 (10.1), 10207 (3.2), 10376 (10.1), 11043 (4.5), 11517 (4.5), 11839 (7.1), 12437 (3.3), 13350 (3.1). Kuhlmann JG 85 (4.12), 180 (4.10). Kuntz J 644 (4.5). Labiak P 4682 (4.14), 5134 (3.3). Lorencini TS 73 (3.4), 192 (3.4). Maas PJM 9820 (6). Machado JO 72 (3.3), 204 (3.3). Magnago LFS 472 (4.1), 473 (4.11), 676 (4.1), 906 (4.1). Manhães VC 202 (1). Marinho LC 731 (4.11). Martinelli G 1882 (4.15), 2041 (4.5), 2044 (4.10). Martins GN 31 (3.2). Moraes QS 35 (4.11), 121 (4.14), 122 (4.14), 123 (4.14), 125 (4.14), 126 (4.14), 133 (3.3), 135 (4.11), 136 (4.11), 138 (4.16), 139 (4.16), 140 (4.16), 141 (4.16), 142 (4.16), 143 (4.12), 144 (4.12), 145 (4.12), 146 (1), 147 (6), 148 (4.12), 150 (3.1), 152 (6), 153 (6), 156 (3.1), 157 (3.3), 158 (4.11), 159 (4.11), 160 (3.1), 165 (4.12), $166(4.12), 167$ (4.16), $168(3.3), 212(3.3), 216(3.5), 230(4.5), 233(4.11), 235(4.11), 238(4.11), 239$ (4.2), 241 (4.16), 242 (4.16), 277 (9.1), 279 (3.1), 280 (3.2), 281 (9.1), 282 (4.12), 283 (4.12), 284 (3.4), 285 (4.3), 287 (5), 288 (4.5), 290 (4.11), 291 (3.5), 292 (4.5), 293 (4.5), 295 (3.5), 286 (4.9), 296 (4.7), 297 (4.11), 298 (4.7), 299 (4.14), 300 (4.14), 301 (4.14), 302 (4.9), 303 (4.3), 304 (6), 305 (4.11), 306 (4.12), 307 (4.12), 312 (9.3). Neves PT 4002 (9.3). Oliveira JA 285 (10.1). Peixoto AL 383 (4.15), 3514 (4.5). Pellegrini MOO 236 (4.12) 238 (4.12), 248 (3.7), 250 (2), 330 (9.2), 337 (7.1), 346 (10.2), 375 (4.10), 377 (4.14), 465 (4.3). Pena NTL 143 (1), 144 (1), 145 (1), 146 (1), 264 (4.11), 274 (3.3), 324 (1). Pereira OJ 269 (4.11), 440 (3.1). Peixoto AL 459 (4.12). Pinheiro H 11 (3.3), 32 (3.3). Pirani JR 6128 (4.1). Pizziolo W 15 (3.4). Ribeiro M 108 (4.10), 993 (4.14), 1222 (10.2). Romão GO 1207 (4.10). Saavedra MM 609 (4.15), 633 (4.4). Santos FL 109 (3.3). Sarnaglia Jr VB 188 (4.14), 643 (10.2), 645 (3.3), 647 (4.15), 654 (4.5). Silva AG 466 (3.1). Siqueira GS 185 (6). Sossai BG 34 (3.1). Souza FBC 49 (3.3). Souza PF 136 (3.3). Souza RLD 13 (3.3). Souza WO 153 (3.1). Stehmann JR 4725 (4.9). Sucre D 8615 (4.12), 8912 (5). Valadares RT 1272 (3.3). Vervloet RR 283 (4.12), 1589 (4.1), 1808 (4.1), 2064 (4.11), 2377 (3.1), 2587 (4.1). Vimercat JM 26 (3.2), 110 (3.4). Weinberg B 271 (9.3), VIES 439 (3.2). Zorzanelli JPF 969 (7.3), 1391 (7.3), 1505 (7.3). 